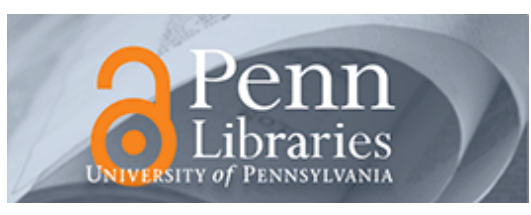

University of Pennsylvania
ScholarlyCommons

University of Pennsylvania Museum of Archaeology University of Pennsylvania Museum of Archaeology and Anthropology Papers and Anthropology

4-1996

\title{
Uruk Colonies and Anatolian Communities: An Interim Report on the 1992-1993 Excavations at Hacinebi, Turkey
}

Gil J. Stein

Reinhard Bernbeck

Cheryl Coursey

Augusta McMahon

Naomi F. Miller

University of Pennsylvania, nmiller0@upenn.edu

See next page for additional authors

Follow this and additional works at: http://repository.upenn.edu/penn_museum_papers

\section{Recommended Citation}

Stein, G. J., Bernbeck, R., Coursey, C., McMahon, A., Miller, N. F., Misir, A., Nicola, J., Pittman, H., Pollock, S., \& Wright, H. (1996). Uruk Colonies and Anatolian Communities: An Interim Report on the 1992-1993 Excavations at Hacinebi, Turkey. American Journal of Archaeology, 100 (2), 205-260. http://dx.doi.org/10.2307/506903

This paper is posted at ScholarlyCommons. http://repository.upenn.edu/penn_museum_papers/35

For more information, please contact repository@pobox.upenn.edu. 


\title{
Uruk Colonies and Anatolian Communities: An Interim Report on the 1992-1993 Excavations at Hacinebi, Turkey
}

\begin{abstract}
The first Mesopotamian city-states in the Uruk period (ca. 3800-3100 B. C.) pursued a strategy of commercial expansion into neighboring areas of the Zagros Mountains, Syria, and southeastern Anatolia. Recent research in these areas has located several Uruk outposts, in what is apparently the world's earliest-known colonial system. Although some Uruk "colonies" have been excavated, virtually nothing is known about either the operation of this system or its role in the development of local polities in Anatolia. Excavations at the site of Hacinebi, on the Euphrates River trade route, investigate the effects of the "Uruk Expansion" on the social, economic, and political organization of southeastern Anatolia during the fourth millennium B. C. Hacinebi has two main Late Chalcolithic occupations - a pre-contact phase A and a later contact phase B with high concentrations of Uruk ceramics, administrative artifacts, and other Mesopotamian forms of material culture. The Hacinebi excavations thus provide a rare opportunity to investigate the relationship between the Uruk colonies and the local populations with whom they traded, while clarifying the role of long-distance exchange in the development of complex societies in Anatolia. Several lines of evidence suggest that the period of contact with Mesopotamia began in the Middle Uruk period, earlier than the larger colonies at sites such as Habuba Kabira-South and Jebel Aruda in Syria. The concentrations of Uruk material culture and the patterns of food consumption in the northeastern corner of the Local Late Chalcolithic settlement are consistent with the interpretation that a small group of Mesopotamian colonists lived as a socially distinct enclave among the local inhabitants of Hacinebi. There is no evidence for either Uruk colonial domination or warfare between the colonists and the native inhabitants of Hacinebi. Instead, the presence of both Anatolian and Mesopotamian seal impressions at the site best fits a pattern of peaceful exchange between the two groups. The evidence for an essential parity in long-term social and economic relations between the Mesopotamian merchants and local inhabitants of Hacinebi suggests that the organization of prehistoric Mesopotamian colonies differed markedly from that of the better-known 16th-20th century European colonial systems in Africa, Asia, and the Americas.
\end{abstract}

\section{Author(s)}

Gil J. Stein, Reinhard Bernbeck, Cheryl Coursey, Augusta McMahon, Naomi F. Miller, Adnan Misir, Jeffrey Nicola, Holly Pittman, Susan Pollock, and Henry Wright 


\title{
Uruk Colonies and Anatolian Communities:
}

\author{
An Interim Report on the 1992-1993 \\ Excavations at Hacinebi, Turkey
}

\author{
GIL J. STEIN, REINHARD BERNBECK, CHERYL COURSEY, AUGUSTA MCMAHON, \\ NAOMI F. MILLER, ADNAN MISIR, JEFFREY NICOLA, HOLLY PITTMAN, \\ SUSAN POLLOCK, AND HENRY WRIGHT
}

\begin{abstract}
The first Mesopotamian city-states in the Uruk period (ca. 3800-3100 B.C.) pursued a strategy of commercial expansion into neighboring areas of the Zagros Mountains, Syria, and southeastern Anatolia. Recent research in these areas has located several Uruk outposts, in what is apparently the world's earliest-known colonial system. Although some Uruk "colonies" have been excavated, virtually nothing is known about either the operation of this system or its role in the development of local polities in Anatolia.

Excavations at the site of Hacinebi, on the Euphrates River trade route, investigate the effects of the "Uruk Expansion" on the social, economic, and political organization of southeastern Anatolia during the fourth millennium B.C. Hacınebi has two main Late Chalcolithic occupations - a pre-contact phase A and a later contact phase B with high concentrations of Uruk ceramics, administrative artifacts, and other Mesopotamian forms of material culture. The Hacinebi excavations thus provide a rare opportunity to investigate the relationship between the Uruk colonies and the local populations with whom they traded, while clarifying the role of
\end{abstract}

* The 1992 and 1993 field seasons of the Joint Şanlıurfa Museum-Northwestern University salvage excavations at Hacınebi Tepe, Turkey were codirected by Gil Stein (Northwestern University) and Adnan Mısır (Şanlıurfa Museum). The excavations were funded with support from the National Endowment for the Humanities, National Geographic Society, the Metropolitan Museum of Art, Northwestern University, and generous private donors.

We wish to express our appreciation to Engin Özgen, General Director of the Ministry of Culture's Directorate of Monuments and Museums, for permission to conduct this research. We also gratefully acknowledge the assistance of Kemal Işık, the Muhtar of Ugurcuk village, for his hospitality and assistance in conducting excavations at Hacinebi.

In addition to the two codirectors, the 1992-1993 proj. ect staff consisted of Ahmet Ayhan (Istanbul University), Reinhard Bernbeck (Freie Universität Berlin), Cheryl Coursey (State University of New York at Binghamton), Julia Frane (University of North Carolina at Chapel Hill), Hamza Güllüce (Şanlıurfa Museum), Kathryn Keith (University of Michigan), Nicola Laneri (Università di Roma), Alan Lupton (Cambridge University), Augusta McMahon (University of Chicago), Naomi F. Miller (University of Penn-

American Journal of Archaeology 100 (1996) 205-60 long-distance exchange in the development of complex societies in Anatolia.

Several lines of evidence suggest that the period of contact with Mesopotamia began in the Middle Uruk period, earlier than the larger colonies at sites such as Habuba Kabira-South and Jebel Aruda in Syria. The concentrations of Uruk material culture and the patterns of food consumption in the northeastern corner of the Local Late Chalcolithic settlement are consistent with the interpretation that a small group of Mesopotamian colonists lived as a socially distinct enclave among the local inhabitants of Hacinebi. There is no evidence for either Uruk colonial domination or warfare between the colonists and the native inhabitants of Hacinebi. Instead, the presence of both Anatolian and Mesopotamian seal impressions at the site best fits a pattern of peaceful exchange between the two groups. The evidence for an essential parity in long-term social and economic relations between the Mesopotamian merchants and local inhabitants of Hacmebi suggests that the organization of prehistoric Mesopotamian colonies differed markedly from that of the better-known 16th-20th century European colonial systems in Africa, Asia, and the Americas.*

sylvania), Jeffrey Nicola (Northwestern University), Susan Pollock (State University of New York at Binghamton), Margaret Reid (Guilford Technical Community College), Lewis Somers (GeoScan Research), Jill Weber (University of Pennsylvania), and Henry Wright (University of Michigan). Illustrations used in this report were drawn or inked by Cheryl Coursey, Bethann Croft, Barbara Foster, Amy Lueker, Alan Lupton, Kristen Morrison, Susan Pollock, Margaret Reid, Gil Stein, Carlene Togul-Friedman, Jill Weber, and Henry Wright.

The senior author (Stein) completed this manuscript with support from a National Endowment for the Humanities Resident Scholarship at the School of American Research, Santa Fe.

The following abbreviations are used:

Adams and $\quad$ R. McC. Adams and H. Nissen, The Uruk Nissen

Algaze 1989 Countryside (Chicago 1972).

G. Algaze, "The Uruk Expansion: Crosscultural Exchange in Early Mesopotamian Civilization," CurrAnthr 30 (1989) 571-608.

Algaze 1993 G. Algaze, The Uruk World System (Chicago 1993).

Deve Hüyük P.R.S. Moorey, Cemeteries of the First Mil- 


\section{INTRODUCTION}

This article represents a collaborative effort to reconstruct the chronology and economic organization of the site of Hacinebi in the Late Chalcolithic and Hellenistic periods. The first section, by Gil Stein and Adnan Misır, presents an overview of Hacinebi's archaeological significance for the study of the Mesopotamian colonial system, followed by a summary of the fourth-millennium B.C. stratigraphy, architecture, and chronology of this strategically located site along the Euphrates River valley trade route (pp. 206-22). Augusta McMahon's contribution (pp. 222-29) completes the stratigraphic history of the site by describing the late first-millennium B.C. settlement at Hacinebi. This occupation spanned both the Late Achaemenid and Early Hellenistic periods, during which time the site played a key role in guarding the southeastern approaches to the city of Zeugma.

The remainder of the paper presents detailed studies of available evidence for the chronology and economic organization of Hacınebi during the Late Chalcolithic period. Holly Pittman studies the contemporaneous but different administrative and accounting systems of cylinder and stamp seal technology used by the Mesopotamian and Anatolian inhabitants of the site (pp. 230-33). Susan Pollock and Cheryl Coursey examine the Uruk-style ceramics from the site (pp. 233-39) and conclude that the Mesopotamian presence began in the mid-fourth mil. lennium, significantly earlier than the larger and better-known Uruk colonies at Habuba Kabira-South and Jebel Aruda. Henry Wright and Reinhard Bernbeck's analysis of the chipped stone artifacts (pp. 239-47) reconstructs patterns of craft production and other economic activities in the fourthmillennium settlement. Naomi Miller summarizes the carbonized plant remains (pp. 248-57), reconstructing the agricultural system of the site, and suggesting that local Anatolian subsistence patterns continued, even during the period of intensive com. mercial contact with Mesopotamia. Gil Stein and Jeffrey Nicola's examination of animal bone remains from Uruk and local areas of the Late Chalcolithic settlement (pp. 257-60) shows clear differences in patterns of meat consumption that are consistent with the contrasting food preferences of Mesopotamian foreigners and the local inhabitants of the site. The overall picture that emerges is one of clear contrasts between the local Anatolian community and the colonial enclave of Mesopotamian traders at the site. The diachronic and synchronic analyses of these two communities provide a rare opportun. ity to study the organization of prehistoric colonial systems and the impact of interregional trade on cultural development in the Near East.

\section{THE FOURTH-MILLENNIUM OCCUPATION OF HACINEBI}

\section{Gil J. Stein and Adnan Misır}

\section{URUK COLONIES AND LOCAL SETTLEMENTS IN THE MESOPOTAMIAN PERIPHERY}

The development of the first Mesopotamian citystates in the Uruk period (the fourth millennium B.C.) seems to have coincided with a period of ag. gressive commercial expansion into neighboring areas of the Zagros Mountains (modern Iran), north-

\footnotetext{
lennium B.C. at Deve Hüyük, near Car. chemish, Salvaged by T.E. Lawrence and C.L. Woolley in 1913 (Oxford 1980).

Hama

A.P. Christensen and C.F. Johansen, Hama: Les poteries hellénistiques et les terres sigillées orientales (Copenhagen 1971).

Schwartz G. Schwartz, "Excavations at Karatut Mevkii and Perspectives on the Uruk/ Jemdet Nasr Expansion," Akkadica 56 (1988) 1-42

Stein and Mısır G. Stein and A. Mısır, "MesopotamianAnatolian Interaction at Hacinebi, Turkey: Preliminary Report on the
}

ern Syria, and southeastern Anatolia. ${ }^{1}$ Several sites in the last two areas have been identified as Uruk trading colonies, apparently established to control trade/communication routes while extracting metals, lumber, or other commodities from the resource rich highland zones, in what several researchers consider the world's earliest-known colonial system. Sites

\section{Sürenhagen The Uruk Period and Subsequent De- velopments," in $\mathrm{H}$. Weiss ed., The Ori- gins of Cities in Dry Farming Syria and Mesopotamia in the Third Millennium B.C. (Guilford, Conn. 1986) 7-43. \\ Tarsus H. Goldman, Excavations at Gözlü Kule, Tarsus I: The Hellenistic and Roman Peri ods (Princeton 1950).}

1992 Excavations," Anatolica 20 (1994) 145-89.

D. Sürenhagen, “The Dry-Farming Belt:

${ }^{\prime}$ G. Algaze, "Expansionary Dynamics of Some Early Pristine States," American Anthropologist 95 (1993) 304-33; Algaze 1993. 
identified as Uruk "colonies" or "enclaves" were established in the key routes through the western Zagros, ${ }^{2}$ on the Tigris River in northern Mesopotamia, ${ }^{3}$ across the Habur headwaters region, ${ }^{4}$ and up the Euphrates River into the Taurus highlands. ${ }^{5}$ The main phase of the Uruk expansion seems to have been in the Late Uruk period (ca. 3400-3100 B.C.), although some sites were established earlier in the Middle Uruk period. ${ }^{6}$

The Uruk enclaves are quite distinctive as alien settlements, established in the midst of local Iranian, Syrian, and southeastern Anatolian cultures. Several different forms of Uruk material culture-ceramics, architecture, and administrative artifacts - occur in combination, and serve to identify the Mesopotamian implanted settlements while distinguishing them from contemporaneous local settlements. Sites identified as "colonies" have the full repertoire of Uruk ceramics ${ }^{7}$ while generally lacking local Anatolian ceramics. By contrast, local sites tend to have

${ }^{2} \mathrm{H}$. Weiss and T.C. Young, Jr., "The Merchants of Susa: Godin V and Plateau-Lowland Relations in the Late Fourth Millennium B.C.," Iran 13 (1975) 1-17.

${ }^{3}$ G. Algaze, "Habuba on the Tigris: Archaic Nineveh Reconsidered," JNES 45 (1986) 125-37.

${ }^{4}$ Schwartz.

${ }^{5}$ Sürenhagen 15; M. Frangipane and A. Palmieri, "Ur. banization in Perimesopotamian Areas: The Case of Eastern Anatolia," in L. Manzanilla ed., Studies in the Neolithic and Urban Revolutions (Oxford 1987) 295-318; U. Esin, “Tepecik Excavations, 1974," in Keban Project 1974-75 Activ. ities (Ankara 1982) 95-125.

${ }^{6} \mathrm{~J}$. Boese, "Excavations at Tell Sheikh Hassan, Prelim. inary Report on the Year 1987 Campaign in the Euphrates Valley," AAS 36/37 (1987) 67-100; J. Oates, "Trade and Power in the Fifth and Fourth Millennia B.C.: New Evidence from Northern Mesopotamia," WorldArch 24 (1993) 403-22.

${ }^{7}$ A. Palmieri, "Eastern Anatolia and Early Mesopotamian Urbanization: Remarks on Changing Relations," in M. Liverani, A. Palmieri, and R. Peroni eds., Studi di paletnologia in onore di Salvatore M. Puglisi (Rome 1985) 191-213; Sürenhagen 26.

${ }^{8}$ Algaze (supra n. 3); Algaze 1989; G. Algaze et al., "The Tigris-Euphrates Archaeological Reconnaissance Project: A Preliminary Report of the 1989-1990 Seasons," Anatolica 17 (1991) 175-240; R. Braidwood and L. Braidwood, Excavations in the Plain of Antioch I (Chicago 1960); K. Fielden, "A Late Uruk Pottery Group from Tell Brak 1978," Iraq 43 (1981) 157-66; E. Henrickson, "The Outer Limits: Settlement and Economic Strategies in the Central Zagros dur. ing the Uruk Era," in G. Stein and M. Rothman eds., Chiefdoms and Early States in the Near East: The Organizational Dynamics of Complexity (Madison 1994) 85-102; Palmieri (supra n. 7); Schwartz; G. Schwartz, A Ceramic Chronology from Tell Leilan (New Haven 1988); P. Wattenmaker and G. Stein, "Leilan 1987 Survey: Uruk Summary," in M. Rothman, "Out of the Heartland: The Evolution of Complexity in Peripheral Mesopotamia during the Uruk Period," Paléorient 15 (1989) 283-84; Weiss and Young (supra n. 2). only a limited range of Uruk ceramic types (notably beveled-rim bowls) occurring alongside the indigenous ceramic assemblage. ${ }^{8}$ The sites with the full Uruk ceramic repertoire also have distinctive Uruk architecture such as the tripartite "middle-hall" house, wall-cone mosaic decoration, and niched facade temples. ${ }^{9}$ A third distinctive feature of the Uruk enclaves is the presence of southern Mesopotamian administrative artifacts such as cylinder seals, bullae, tokens, and clay tablets with numerical inscriptions used to monitor the mobilization, transportation, storage, and disbursement of goods. ${ }^{10}$ Based on these criteria, researchers have identified Uruk enclaves at Godin, in Iran; at Brak and Nineveh in northern Mesopotamia; and on the Syrian Euphrates at Qraya, Habuba Kabira-South, Sheikh Hassan, and Jebel Aruda. ${ }^{11}$ On the Euphrates in Anatolia, excavations have identified Uruk enclaves at Hassek Höyük, Samsat, and Tepecik. ${ }^{12}$

The purpose of these implanted Uruk settlements

\footnotetext{
${ }^{9}$ Sürenhagen 10; M.R. Behm-Blancke, "Mosaikstifte aus der Uruk-Zeit am Oberen Euphrat," IstMitt 39 (1989) 73-83; N. Özgüç, "The Uruk Culture at Samsat," in B. Hrouda, S. Kroll, and P. Spanos eds., Von Uruk nach Tuttul. Eine Fest. schrift für Eva Strommenger (Munich 1992) 151-65; A. Özten, "Two Pots Recovered in the Excavations at Samsat Belong. ing to the Late Chalcolithic Period," Anadolu 20 (1984) 261-69; A. Finet, "L'apport du Tell Kannas a l'histoire proche-orientale, de la fin du $4^{\mathrm{e}}$ millénaire à la moitié du $2^{\mathrm{e}}$," in J.C. Margueron ed., Le Moyen Euphrate: Zone de contact et d'échanges (Leiden 1977) 107-15; G. van Driel, "The Uruk Settlement at Jebel Aruda: A Preliminary Report," in Margueron, 75-93; G. van Driel and C. van Driel-Murray, “Jebel Aruda 1977-1978," Akkadica 12 (1979) 2-28.

${ }^{10} \mathrm{H}$. Nissen, "The Emergence of Writing in the Ancient Near East," Interdisciplinary Science Reviews 10 (1985) 349-61; H. Pittman, "Pictures of an Administration: The Late Uruk Scribe at Work," in M. Frangipane et al. eds., Between the Rivers and over the Mountains (Rome 1993) 235-46; G. van Driel, “Tablets from Jebel Aruda," in G. van Driel et al. eds., Zikir Sumim. F.R. Kraus Festschrift (Leiden 1982) 12-25; van Driel, "Seals and Sealings from Jebel Aruda 1974-1978," Akkadica 33 (1983) 34-62; H. Wright, N. Miller, and R. Redding, "Time and Process in an Uruk Rural Center," in M.T. Barrelet ed., L'archéologie de l'Iraq du début de l'époque néolithique à 333 avant notre ère: Perspectives et limites de linterpretation anthropologique des documents (Paris 1981) 265-84.

${ }^{11}$ Weiss and Young (supra n. 2); Algaze (supra n. 3); Schwartz; Sürenhagen; Boese (supra n. 6); S. Reimer, “Tell Qrayya on the Middle Euphrates," in Rothman (supra n. 8) 284; E. Strommenger, Habuba Kabira: Eine Stadt vor 5000 Jahren (Mainz 1980); G. van Driel and C. van Driel-Murray, "Jebel Aruda, the 1982 Season of Excavation: Interim Report," Akkadica 33 (1983) 1-26.

${ }^{12}$ Algaze (supra n. 3); Algaze 1989; M. Behm-Blancke, "Hassek Höyük: Vorläufiger Bericht über die Ausgrabungen der Jahre 1978-1980," IstMitt 31 (1981) 5-82; Behm-Blancke, "Die Ausgrabungen auf dem Hassek Höyük im Jahre 1985," in VIII. Kazı Somuçları Toplantısı (Ankara 1986) 139-47; Algaze
} 
remains the subject of continued debate..$^{13}$ Many researchers, however, see the Uruk enclaves as trading colonies or way stations whose primary purpose was to insure southern Mesopotamian access to Anatolian and Iranian natural resources as part of a prehistoric "world system."14

\section{THE STUDY AREA}

Although Uruk "colonies" and "outposts" in Syria and Anatolia have been excavated, we know almost nothing about the impact of this interregional trade system on the political, social, and economic systems of the indigenous cultures in southeastern Anatolia. The Hacınebi excavations investigate the effects of Uruk Mesopotamian commercial expansion on local Anatolian cultures. Hacinebi is the ideal site to elucidate this problem, since it is an indigenous settle. ment, strategically located near the Uruk enclaves on the Euphrates River trade route, and shows clear signs of contact with Mesopotamia during the fourth millennium B.C. The Hacınebi stratigraphic sequence allows a diachronic study of Anatolian political economy both before and during the Uruk expansion.

Hacinebi is a low mound 3.3 ha in size, located on the bluffs overlooking the east bank of the Euphrates River in Şanlıurfa province, southeastern Turkey (fig. 1). The site lies near the head of the main north-south riverine trade route along the $\mathrm{Eu}$ phrates; it also occupies a strategic location on what has historically been the major east-west river crossing point at Birecik. ${ }^{15}$ The mound of Hacinebi is situated on an easily defensible east-west oriented spur that drops down steeply to the river on the west side, and into deep canyons to the north and south. The mound itself consists of approximately $9 \mathrm{~m}$ of cultural deposits at the east end; these become gradually shallower toward the west, following the natural surface of the spur as it slopes down toward the Euphrates.

et al. (supra n. 8); U. Esin, "Die kulturellen Beziehungen zwischen Östanatolien und Mesopotamien sowie Syrien anhand einiger Grabungs und Oberflächenfunde aus dem Oberen Euphrattal im 4 Jt. v. Chr.," in H. Nissen and J. Renger eds., Mesopotamien und seine Nachbärn (Berlin 1982) 13-21; Esin (supra n. 5).

13 G. Johnson, "Late Uruk in Greater Mesopotamia: Expansion or Collapse?" Origini 14 (1988-1989) 595-613; Schwartz; G. Stein, "On the Uruk Expansion," CurrAnthr 31 (1990) 66-67; P. Wattenmaker, "On the Uruk Expansion," CurrAnthr 31 (1990) 67-69.

${ }^{14}$ A. Palmieri, "Excavations at Arslantepe (Malatya)," AnatSt 31 (1981) 101-19; Sürenhagen; Palmieri (supra n. 7); Frangipane and Palmieri (supra n. 5); Algaze 1989; Algaze 1993.

1.5 al Idrisi, Géographie d'Edrisi (Paris 1840) 137; F.R.
The Tigris-Euphrates survey project conducted by Guillermo Algaze discovered Hacınebi and identified its main occupation as Late Chalcolithic, comprising both local southeastern Anatolian forms contemporaneous with Amuq F/G and southern Mesopotamian Uruk ceramic forms. ${ }^{16}$ The only post-Chalcolithic deposits at Hacınebi are an Achaemenid/ Hellenistic occupation, and a small Roman farmstead at the west end of the site. The stratigraphy of this site provides a rare chance to make the broad horizontal exposures necessary to recover a representative sample from a fourth-millennium B.C. settlement.

In 1992 Northwestern University and the Şanlıurfa Museum began a long-term excavation project at Hacinebi. ${ }^{17}$ The first two field seasons in the summers of 1992 and 1993 focused on the stratigraphic sequence and the range of variation in the fourthmillennium settlement, investigating the concentration of Mesopotamian ceramics in the northeastern part of the site, and the architectural traces on the southeastern margin of the mound. Additional trenches were opened on the top of the mound and its western slope. In total, nine trenches exposed an area of ca. $450 \mathrm{~m}^{2}$ and reached sterile soil in the northern, southern, and western areas of the site (fig. 2). Two main fourth-millennium B.C. phases of occupation were defined based on stratigraphy, ar. chitecture, and associated ceramics: an earlier phase A with only local southeastern Anatolian Late Chal. colithic ceramics, and an overlying phase B, which had both local and southern Mesopotamian Uruk types.

\section{HACINEBI PHASE A}

The 1992-1993 excavations recovered phase A deposits in limited exposures directly on top of sterile soil in the northeastern (operation 1), southeastern (operation 2), and western (operation 5) areas of the mound. Three Ubaid painted sherds and two Pre-

Chesney, The Expedition for the Survey of the Rivers Euphrates and Tigris (London 1850) 45; A Handbook of Mesopotamia (London 1916) 167; Turkey. Naval Intelligence Division Handbook (London 1942) 367; L. Dilleman, Haute Mésopotamie orientale et pays adjacents (Paris 1962); D. Oates, Studies in the Ancient History of Northern Iraq (London 1968); J. Wagner, Seleukeia am Euphrat/Zeugma (Wiesbaden 1976).

${ }^{16}$ Braidwood and Braidwood (supra n. 8); Algaze et al. (supra n. 8); G. Algaze, R. Breuninger, and J. Knudstad, "The Tigris-Euphrates Archaeological Reconnaissance Project: Final Report of the Birecik and Carchemish Dam Sur. vey Areas," Anatolica 20 (1994) 1-96.

${ }^{17}$ Stein and Misır; G. Stein and A. Misır, "Hacınebi Ex. cavations, 1992," in XV. Kazı Sonuçları Toplantısı (Ankara 1994) 131-52; Stein and Mısır, "Hacınebi Excavations, 1993," in XVI. Kazı Sonuçları Toplantısı (Ankara 1995) 121-40. 


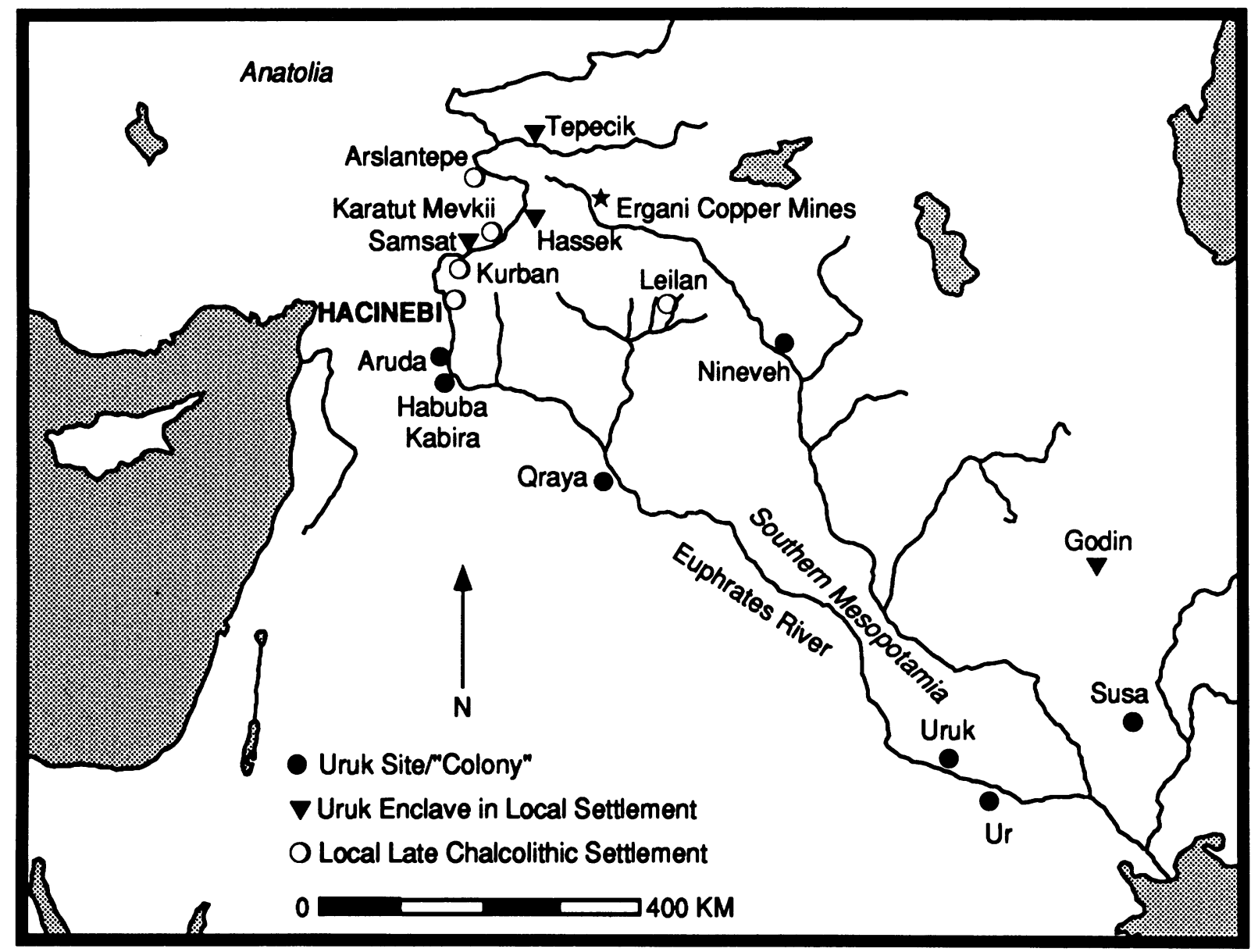

Fig. 1. Map of the fourth-millennium B.C. Near East, showing major Uruk sites, "colonies," and Local Late Chalcolithic settlements in southeastern Anatolia

Pottery Neolithic B diagnostic lithics have been found mixed in later contexts, suggesting that smaller, more ephemeral occupations from earlier periods may be represented in some deeply buried portion of the Hacınebi spur; it is clear, however, that the first largescale occupation of the site did not take place until the early fourth millennium. Typological parallels to the Hacinebi phase A ceramics suggest that this occupation dates to the first half of the fourth millennium. The assemblage is characterized by the predominance of Local Late Chalcolithic chaff-tempered ceramics roughly contemporaneous with Amuq F/G. Chaff-tempered handmade buff wares are widely distributed along the interface zone between the eastern Taurus Mountains and the Syrian steppe, from the Euphrates valley in the west to the Habur head.

${ }^{18}$ Cf. J. Oates, "Tell Brak: The Uruk/Early Dynastic Se. quence," in U. Finkbeiner and W. Röllig eds., Gamdat Nasr: Period or Regional Style? (Wiesbaden 1986) 245-73, fig. 1.3; Schwartz 1988 (supra n. 8) fig. 59.1-2.

${ }^{19}$ Stein and Misır figs. 11-12. waters region in the east. ${ }^{18}$ Two main classes of wares are characteristic of Hacınebi phase A. The Local Late Chalcolithic coarse and medium wares are almost always hand-built, chaff-tempered, and unevenly fired at relatively low temperatures in an oxidizing atmosphere, yielding a paste that generally has a dark core and a pale brown to pink sur. face, often with burnishing. ${ }^{19}$ The second main class of phase A ceramics consists of wheelmade, mineraltempered, fine ware carinated bowls and small jars, generally well fired with smoothed, pale brown surfaces. ${ }^{20}$ Grit-tempered wares form $12-15 \%$ of the phase A ceramic assemblage. The Hacınebi phase A ceramics have parallels at sites in southeastern Turkey and northern Syria such as Kurban Höyük VIB and Leilan V.21

\footnotetext{
${ }^{20}$ Stein and Misır fig. 11: i, p-r.

${ }^{21}$ G. Algaze ed., Town and Country in Southeastern Anatolia 2: The Stratigraphic Sequence at Kurban Höyük (Chicago 1990) pls. 34: A-D, and 40: A, D; Braidwood and Braidwood (supra n. 8) fig. 176.14 and 23 and fig. 179.280; G. Schwartz, From
} 


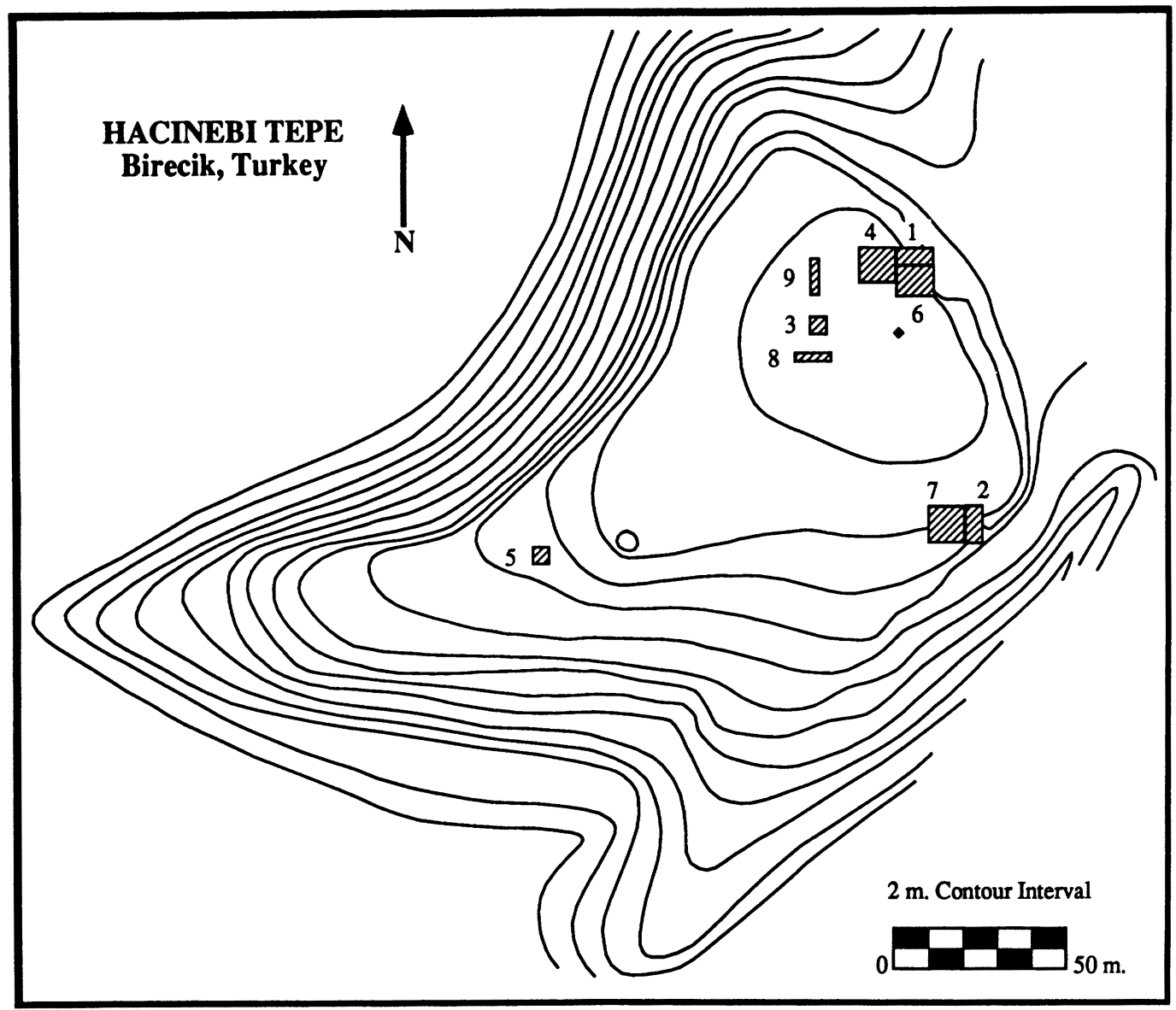

Fig. 2. Hacınebi Tepe: main excavation areas in 1992 and 1993

This earliest main occupation at Hacmebi was exposed by excavations in a $4 \times 10.5 \mathrm{~m}$ trench, operation 1, where $2 \mathrm{~m}$ of phase A deposits underlie the phase B and Achaemenid/Hellenistic strata (fig. 3). The phase $A$ architecture is constructed directly on sterile gravels $8.69 \mathrm{~m}$ below the site datum at the summit of the mound. The most significant phase A architecture in operation 1 was a massive wall foundation (wall 92) $1.5 \mathrm{~m}$ wide and $1.2 \mathrm{~m}$ high, constructed of unworked limestone masonry. The wall is oriented northwest-southeast, running along the eastern edge of the mound, and is set into a deliberately laid bed of compact silts and gravel as a leveling foundation. The top of wall 92 is flat and possibly served as the footing for a thick mudbrick wall that is no longer preserved. The function of this architecture is uncertain, but its size and location sug.

Prehistory to History on the Habur Plains: The Operation I Ceramic Periodization from Tell Leilan (Diss. Yale Univ. 1982) figs. 44.2 and $45.3-8$.

${ }^{22}$ A. Tobler, Excavations at Tepe Gawra II: Levels $I X-X X$ gest that it might have originally served as a fortification on the side of the mound most vulnerable to attack. Alternatively, the wall may have been built as a terrace to level off a raised area at this end of the site. The wall passed out of use at some point in phase A, as seen by the accumulation of silt and gravel layers up against and eventually over the top of the masonry.

Mortuary practices in phase A continue the local southeastern Anatolian tradition of jar burials of infants and small children. This tradition may be related to or derived from the earlier fifth-millennium Ubaid-related practice of infant jar burials seen at sites such as Gawra and Abada. ${ }^{22}$ Infant jar burials are also known from Late Chalcolithic levels at Samsat, ${ }^{23}$ contemporaneous with Hacinebi. At Hacınebi, six jar burials (and four burials of infants

(Philadelphia 1950) 107; S.A. Jasim, The Ubaid Period in Iraq: Recent Excavations in the Hamrin Region (Oxford 1985) 33-49. 23 Özgüç (supra n. 9) 152. 


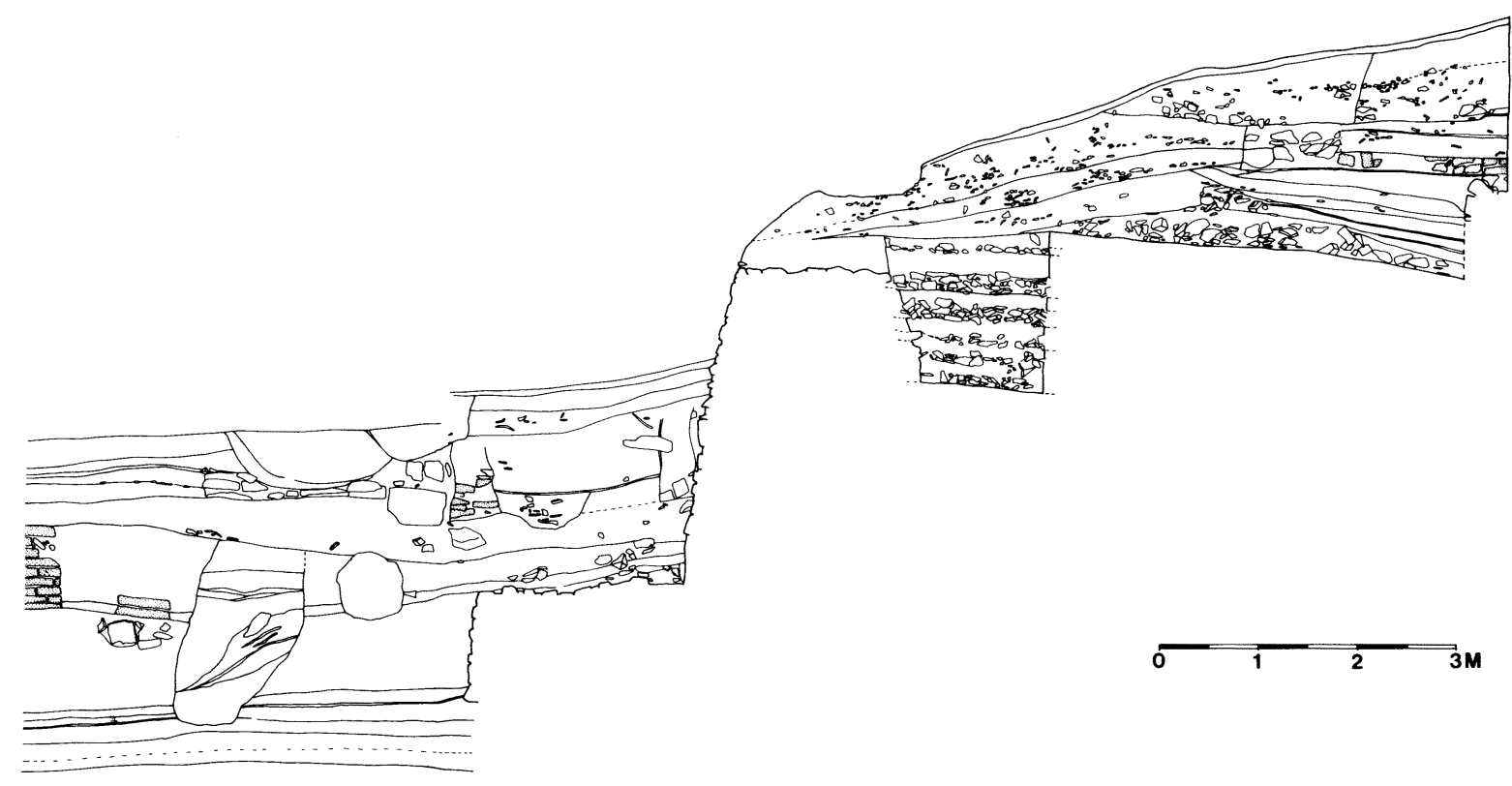

Fig. 3. Operation 1, south section

not in jars) were found in operation 1. The burials were articulated, with no grave goods. Skeletal analy. sis of a sample of four burials indicated that the in. dividuals ranged in age from neonates to four-yearold children. ${ }^{24}$ The deceased were placed in large chaff-tempered storage jars (or occasionally recycled large cooking vessels), with overturned platters or bowls as lids. The jars had been placed in trash, wash, and leveling fill deposits, indicating that these were extramural burials in what was apparently an open area at the edge of the settlement. This burial practice continues into phase $B$ as well. No adult burials have been recovered as yet from either of the Late Chalcolithic phases. The absence of adults may reflect the small area sampled or it may indicate that adults were buried in an as yet undiscovered cemetery outside of the settlement.

On the southeastern slope of the site, phase A deposits were reached in the $5 \times 15 \mathrm{~m}$ exposure of operation 2. The 1992-1993 excavations reached sterile gravels at the base of the site and identified two main phase A building levels beneath the later phase B and Achaemenid/Hellenistic deposits. Building level $\mathrm{Al}$ is founded directly on sterile gravels (fig. 4). A single-course terrace enclosure wall was constructed from large limestone rocks, and was filled in with gravel to make a stable platform for the level Al buildings. Traces of three separate structures were

${ }^{24}$ A. Grauer, "Appendix 2: Paleopathological Analysis of Four Late Chalcolithic Burials from Hacınebi Tepe," recovered. The best-preserved building consists of two rooms linked by a doorway. The building is well constructed of mudbrick, with outer walls more than $1 \mathrm{~m}$ thick built on stone footings. The inner walls of both rooms were plastered. No hearths, basins, or storage features were present in the exposed portions of the room interiors. Deposits inside the rooms were clean, containing almost no artifacts. The walls in building level A1 were preserved up to a height of $1 \mathrm{~m}$, at which point they were truncated by the construction of the much larger level A2 mudbrick building. It is possible that the level Al building was deliberately filled in to form a footing for the massive level A2 structure.

Building level A2 reflects a major architectural reorganization in this part of the site. Excavations revealed that the mudbrick visible on the surface in modern pits at the edge of the mound formed part of a massive mudbrick building, oriented northeastsouthwest, with at least one wall $1.70 \mathrm{~m}$ thick. Both floor deposits and post-abandonment refuse layers in this building contained only Local Late Chalco. lithic ceramics. Excavations of the portion of the structure that extended into operation 2 exposed a niche in the north wall, with a small plaster installation built on the floor in front of it. On the floor of the niched room, a small carved gray stone pendant was found, apparently made of chlorite (fig. 5).

Anatolica 20 (1994) 173-76. 


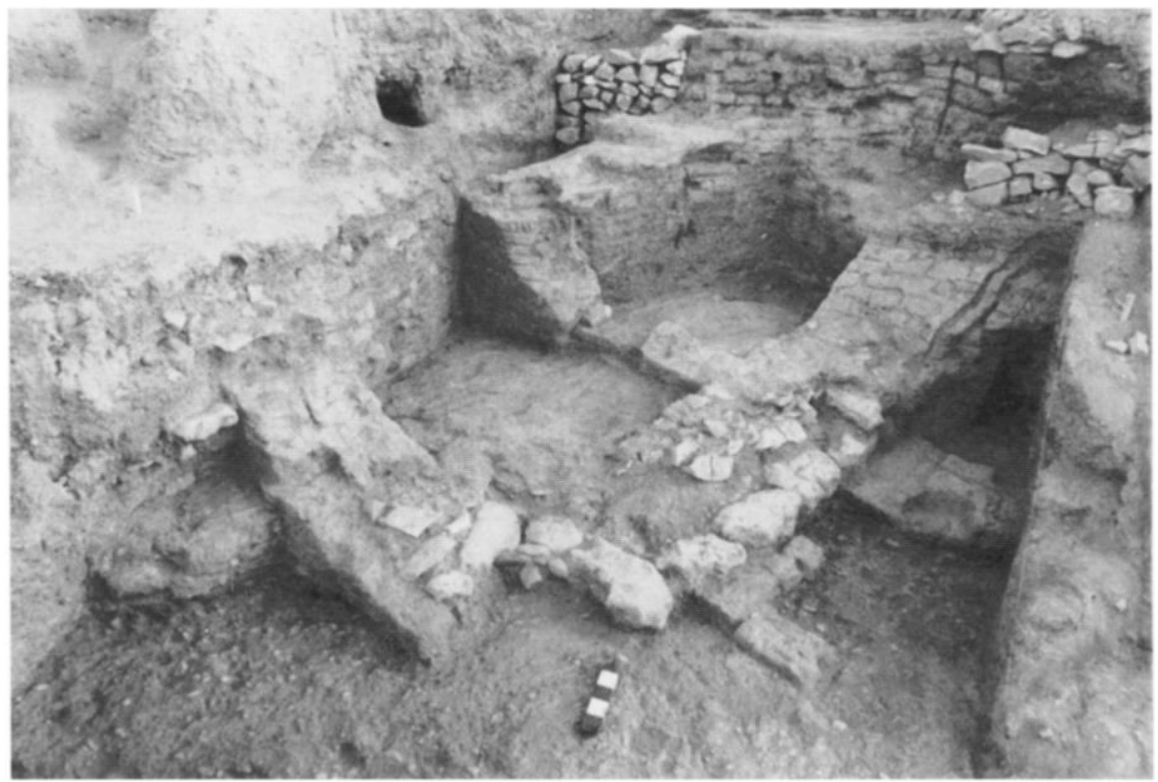

Fig. 4. Operation 2, phase Al architecture, constructed on sterile soil

Since the nearest-known chlorite sources are in the Diyarbakır region some $300 \mathrm{~km}$ away, ${ }^{25}$ the Hacinebi pendant apparently provides evidence for regional exchange systems antedating the Uruk expansion into southeastern Anatolia. The size of the level A2 wall and the presence of a niche/basin suggest that this was a public building of some sort rather than a domestic structure. After several rebuilding episodes, the building was abandoned. The tops of the walls show evidence of exposure and erosion, indicating a possible hiatus in the use of this portion of the site at the end of phase A.

On the western slope of the site, operation 5 was opened as a $5 \times 5 \mathrm{~m}$ trench in order to investigate the extent of Late Chalcolithic occupation. In con-
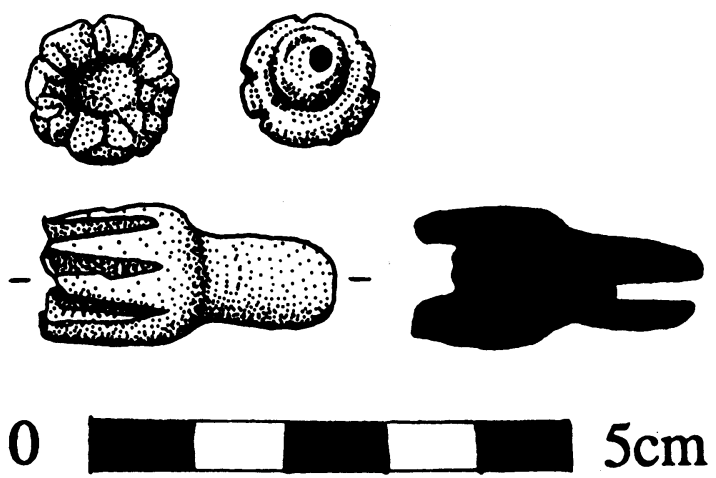

Fig. 5. Carved chlorite pendant HN928, phase A2, operation 2, locus 29 , lot 70 trast to the other trenches at Hacinebi, operation 5 had only limited amounts of later material (from an Early Roman pit) overlying the Late Chalcolithic; fourth-millennium deposits were present almost immediately beneath the plow zone. Excavation recovered a well-stratified sequence of three phase A building levels. The earliest of these was characterized by both stone and mudbrick walls identified in a restricted $2 \times 1 \mathrm{~m}$ deep sounding. These overlay a deposit containing an infant jar burial. In the second phase A building level, broader exposures cleared structures that appear to be small house rooms and associated outdoor areas or courtyards abutting a large stone wall to the north. The rooms are constructed of small, $60 \cdot \mathrm{cm}$-wide walls made of irregularly shaped mudbricks (fig. 6). The courtyards are paved with gravel and contain hearths or small pits. The ceramics, lithics, animal bones, and small finds (e.g., small fragments of animal figurines, spindle whorls, simple beads) are all consistent with refuse from domestic contexts. A large rounded basalt milling stone was set into the courtyard floor, next to the door of one of the rooms. The closest and most likely source for this and other basalt at Hacınebi is the Arat Dağ outcrop, $15 \mathrm{~km}$ to the east. Sterile gravels in operation 5 were reached at a depth of only $1.6 \mathrm{~m}$ beneath modern ground surface, in. dicating that cultural deposits are much shallower on the west slope of the mound.

Overall exposure of phase A deposits in the

${ }^{25}$ Philip Kohl, personal communication. 


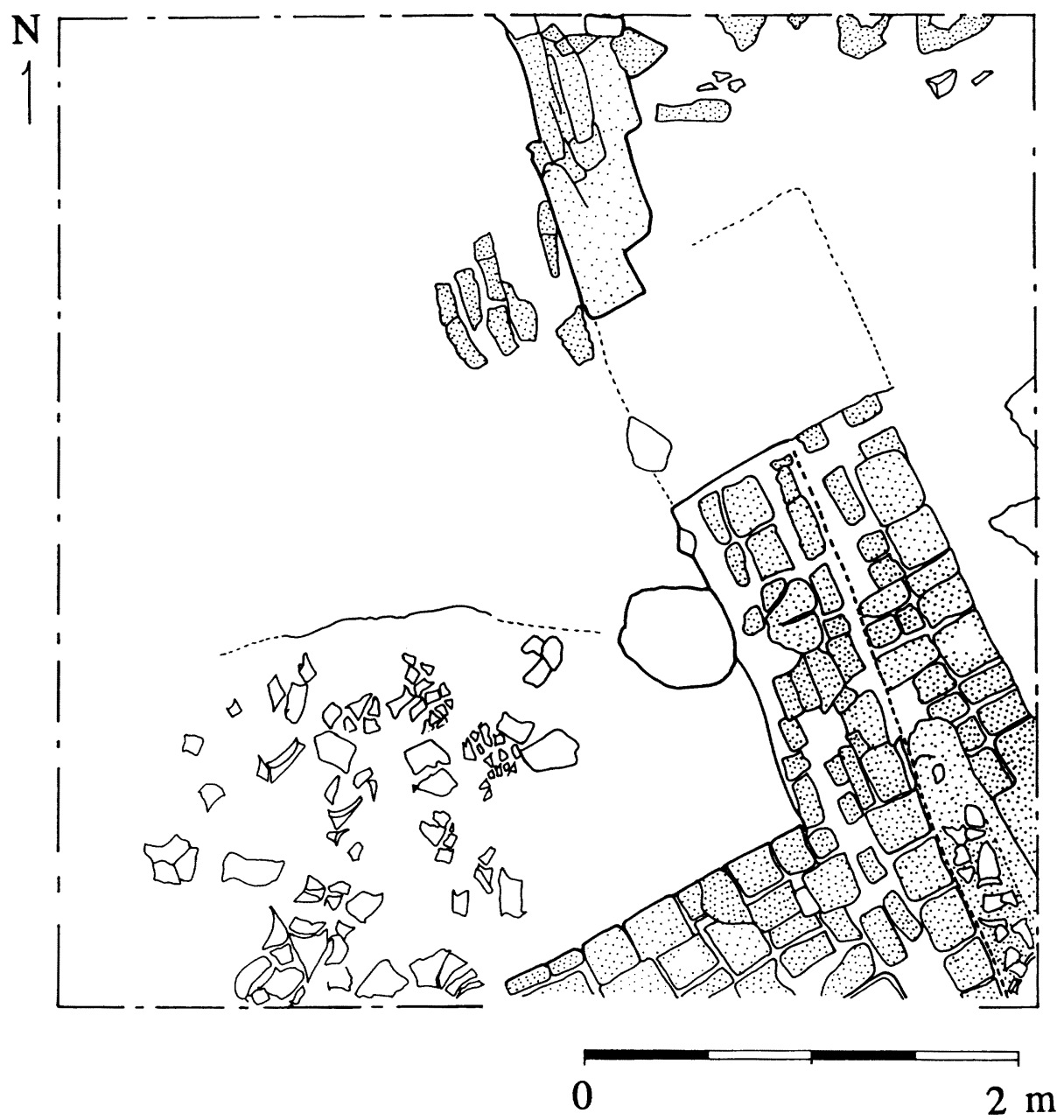

Fig. 6. Operation 5, phase A domestic architecture

1992-1993 seasons was extremely limited, comprising no more than ca. $85 \mathrm{~m}^{2}$ in three different parts of the site. As a result, we can only make a few very tentative general comments about site organization in the period before Mesopotamian contact. First, sampling of three different parts of the site recovered phase A material as the earliest in situ cul. tural deposits in every sounding down to sterile soils, suggesting that the major settlement at Hacınebi was founded in phase A. Based on the distribution of the phase A deposits in operations 1, 2, and 5, it is clear that the settlement was at least 1.3 ha large and may well have extended over an even larger area. The three excavation areas show a surprising amount of intrasite architectural variation. The presence of a large-scale (possibly defensive) wall in

\footnotetext{
${ }^{26}$ M. Frangipane, "Local Components in the Development of Centralized Societies in Syro-Anatolian Regions,"
}

operation 1, a monumental nondomestic mudbrick building in operation 2 , and evidence for both shortand long-distance exchange is consistent with the data from contemporaneous highland sites such as Arslantepe, where evidence for public buildings, craft specialization, ceramic mass production, and metallurgy suggests the beginnings of social complexity in southeastern Anatolia during the early fourth millennium. ${ }^{26}$

\section{HACINEBI PHASE B}

The 1992-1993 excavations exposed phase B deposits over a total area of ca. $250 \mathrm{~m}^{2}$ in the north. ern (ops. 1,6), southern (ops. 2, 7), and western (op. 5) parts of the site. Hacinebi phase B shows great continuity in ceramic styles and burial practices with

in Frangipane et al. (supra n. 10) 133-61. 


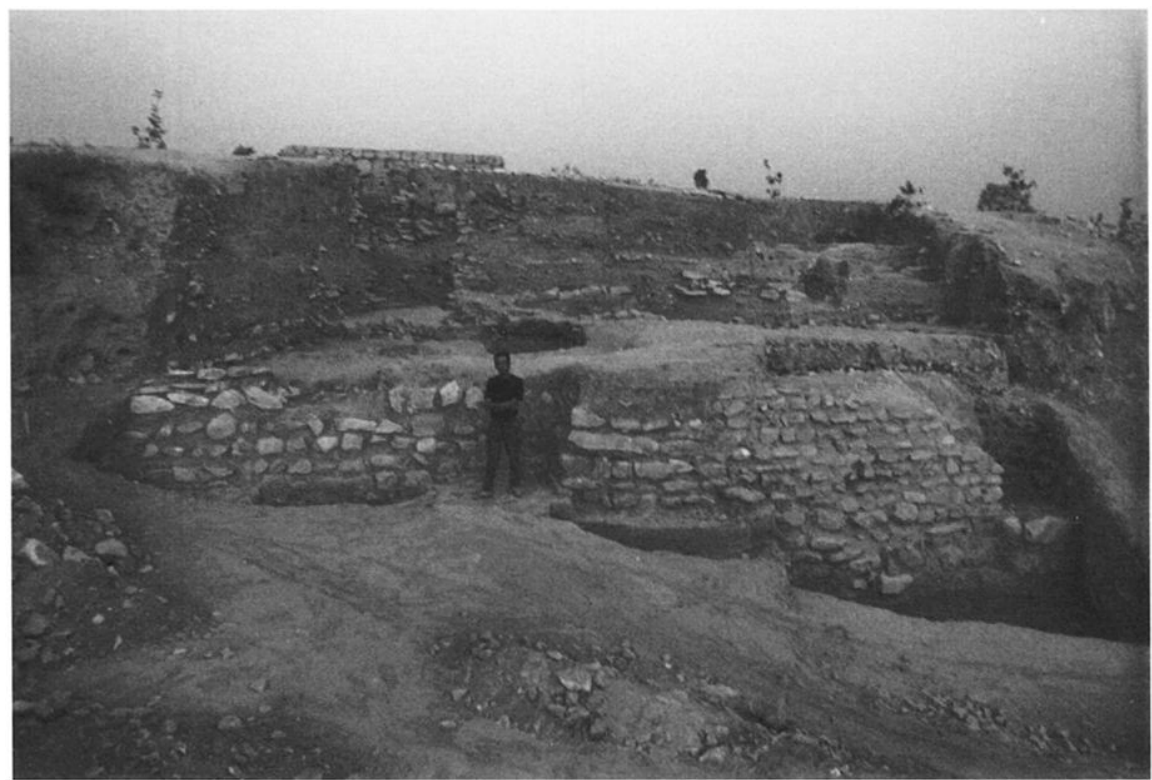

Fig. 7. Operation 1/6, phase B stone terrace platform

the preceding phase A. ${ }^{27}$ The beginning of phase $\mathrm{B}$ is defined by the appearance of Mesopotamian Uruk-style ceramics alongside the Local Late Chalcolithic wares. It is important to emphasize that the Uruk-style material appears as an additional element to the local assemblage, rather than a transforma. tion of the indigenous material culture. The phase $B$ local wares show close continuity with the earlier phase $\mathrm{A}$, with roughly the same ratio of $85 \%$ chaff to $15 \%$ grit-tempered wares. The most salient feature of the phase $B$ assemblage is the presence of large amounts of Mesopotamian Uruk-style ceramics, which are described below by Pollock and Coursey. The find of at least two partially vitrified kiln wasters of identifiable Uruk ceramic types such as band-rim storage jars strongly suggests that the Uruk-style ceramics were actually manufactured at Hacinebi, rather than imported from Mesopotamia. The spatial distribution of Uruk and local ceramics showed great variability within the phase B settlement. Controlled surface collections indicated that both Uruk and local ceramics are present over almost the entire 3.3-ha area of Hacinebi. The vast majority of Uruk ceramics, however, were recovered from operations 1 and 6 in the northeastern corner of the site, while Local Late Chalcolithic chaff-tempered wares predominated in operation 2 , along the southern slope.

In the northeastern part of the site, the appearance of Uruk Mesopotamian ceramics coincides with

\footnotetext{
${ }^{27}$ Stein and Misır; S. Pollock and C. Coursey, "Ceramics from Hacinebi Tepe: Chronology and Connections,"
}

a major architectural reorganization in operations 1 and 6 . A massive $2.80 \cdot \mathrm{m} \cdot \mathrm{high}$ stone terrace wall was constructed (fig. 7), and the area behind it filled in with alternating layers of mud and pieces of angular limestone. A mudbrick retaining wall was built around the top of this raised platform. Uruk ceramics appear in the earliest deposits resting against the terrace wall, and are absent from the deposits underlying that wall. A series of non-monumental (possibly residential) rooms were then built up against the base of the terrace platform. Both local types and large amounts of Uruk Mesopotamian ceramics were present in the rooms and associated trash deposits on top of the platform terrace. Mortuary practices in the rooms at the base of the terrace platform wall continue the phase A practice of infant jar burials. No jar burials were found in the deposits on top of the platform terrace.

Nine distinct phase $\mathrm{B}$ building levels have been de fined on top of the terrace platform. In all cases, the phase B buildings are oriented northwest-southeast, parallel to the line of the terrace wall face. The latestpreserved building levels are mostly mudbrick. The earlier building levels are well-planned, large stone structures. Building level 7 seals off two plastered pits, 76 and 84 , which were cut down into the surface of the platform terrace. Inside pit 84 , over 100 local-style stamp seal impressions were recovered, along with numerous pieces of shaped, unbaked clay

Anatolica 21 (1995) 101-41. 
bearing the impressions of wood, string, rope, leather, reeds, and basketry (see Pittman, below). Stamp seals of this style apparently represent a local version of the more broadly distributed Local Late Chalcolithic glyptic tradition known from Arslantepe and Samsat in southeastern Anatolia, Gawra in northern Iraq, and Brak in northern Syria in the mid-late fourth millennium. ${ }^{28}$ The presence of sealings indicates that Hacınebi was somehow involved in administering the movement of goods during phase B. The form, style, and use of the stamp seals suggest that local Anatolian, as opposed to Mesopotamian, individuals/ offices were active participants in the mobilization, storage, and exchange of commodities at Hacınebi. Examination of the seal impressions showed that only a small number of stamp seals were used. The five most frequently occurring seal impressions account for about 40 of the specimens recovered from pit 84 (see below). The ceramics associated with the local sealings are exclusively Anatolian local Late Chalcolithic types, with no Uruk Mesopotamian diagnostics present. It is highly significant that both local Anatolian stamp seals and Uruk Mesopotamian cylinder seals were used in the northeastern part of Hacınebi during phase $B$.

The earliest-preserved architectural evidence on top of the platform is wall 71, which lies mostly inside the west profile. It is a well-built large stone wall with a rounded buttress in its southeastern corner and apparently is part of a major public building. The earliest refuse deposits lying directly on the surface of the terrace platform contain large amounts of Uruk pottery, an Uruk clay wall cone, and a carved limestone "eye idol" (fig. 8: A), which closely resembles the eye idols found at Tell Brak. ${ }^{29}$ Similarly, the plain, "dimpled," and bitumen-dipped wall cones from Hacinebi (fig. 8: B-D) find close parallels in the wall cones from the Uruk deposits at nearby sites such as Şadi Tepe $15 \mathrm{~km}$ to the south, and with those at Hassek Höyük and Samsat in the Karababa basin to the northeast. ${ }^{30}$

On top of the platform terrace, the Anatolian and

\footnotetext{
${ }^{28}$ P. Ferioli and E. Fiandra, "Clay Sealings from Arslantepe VIA: Administration and Bureaucracy," Origini 12 (1983) 455-509; Palmieri (supra n. 7); Frangipane and Palmieri (supra n. 5); N. Özguç, "Samsat Mühürleri," Belleten 200 (1988) 429-40; Tobler (supra n. 22); M. Rothman, Centralization, Administration, and Function at Fourth Millennium B.C. Tepe Gawra, Northern Iraq (Diss. Univ. of Pennsylvania 1988); M. Rothman and M.J. Blackman, "Monitoring Administrative Spheres of Action in Late Prehistoric Northern Mesopotamia with the Aid of Chemical Characterization (INAA) of Sealing Clays," in N.F. Miller ed., Economy and Settlement in the Near East: Analyses of Ancient Sites and Materials
}

Mesopotamian ceramic traditions usually occurred together in the same contexts, as is the case at Kurban Höyük VIA, Karatut Mevkii, Brak, and Leilan IV. ${ }^{31}$ Some stratigraphically contemporaneous deposits, however, showed clear spatial differences between the distributions of Local and Uruk ceramics. On the western side of operation 1 wall 10 ( = op. 6 wall 45 ), ceramics consisted almost exclusively of Local Late Chalcolithic types. By contrast, contemporaneous deposits on the eastern side of the same wall yielded almost entirely Uruk Mesopotamian ceramics, with only a handful of Local Late Chalcolithic sherds present. Beveled-rim bowls were ubiquitous on the "Uruk" side of the wall - over 4,300 fragments from a single deposit in an area only $3 \times 3 \mathrm{~m}$ wide. Many of the beveled-rim bowls seem to have been used only once before being discarded. This same deposit also yielded a wide variety of other Uruk diagnostics, including fine conical cups (often with lip spouts), ladles, red-slipped wares, droop spouts, chaff-tempered trays/platters, and a wide range of storage jars. Grit-tempered crude conical cups with string-cut bases generally occur in association with the above-mentioned types, and are probably related to Uruk wares, although some researchers have also argued that they may be a Local Late Chalcolithic form (see Pollock and Coursey, below).

The contrast between ceramic assemblages on the two sides of wall $10 / 45$ appears clearly in a comparison of ware types. Beveled-rim bowls and grittempered wares comprise over $96 \%$ of the Uruk assemblage in loci 12 and 16 . By contrast, the purely local assemblage in locus 13 on the western side of wall 10 contains over $83 \%$ chaff-tempered wares, and only $16.71 \%$ grit-tempered wares, with no beveled. rim bowls present at all.

One of the most unusual aspects of the phase $B$ material on the platform terrace is the frequent pres. ence of bitumen in the deposits with exclusively Uruk pottery. The bitumen occurs in several forms, sug. gesting a wide range of uses, e.g., a shaped piece bearing reed impressions on one side and the shape of

(MASCAP 7, Suppl., Philadelphia 1990) 19-45; B. Buchanan, Catalogue of Ancient Near Eastern Seals in the Ashmolean Museum II: The Prehistoric Stamp Seals (Oxford 1984) 19-25.

${ }^{29}$ M.E.L. Mallowan, "Excavations at Brak and Chagar Bazar," Iraq 9 (1947) 1-87.

${ }^{30}$ G. Algaze, "A New Frontier: First Results of the Tigris Euphrates Archaeological Reconnaissance Project, 1988," JNES 48 (1989) 241-81, fig. 36; Behm-Blancke (supra n. 9); Özten (supra n. 9).

31 Algaze (supra n. 21) 260-80; Schwartz; Oates (supra n. 18). 

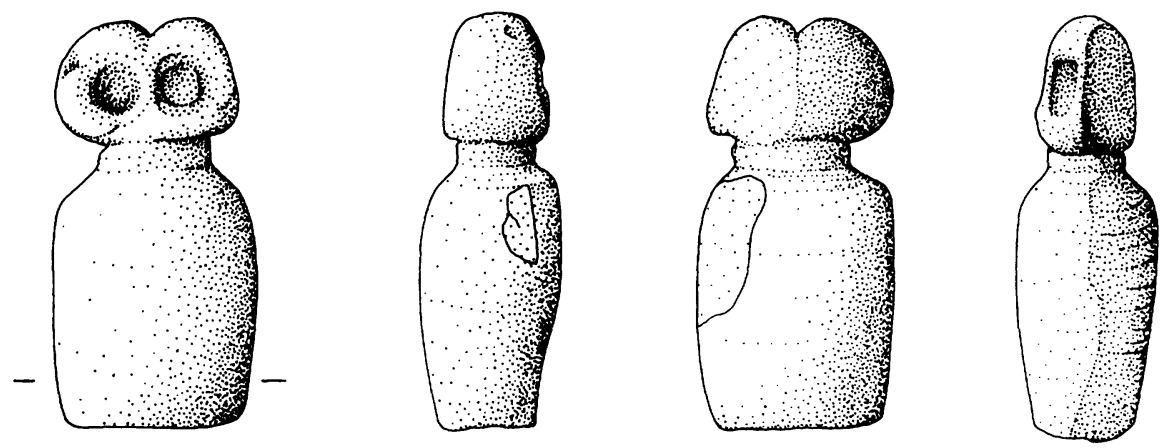

A
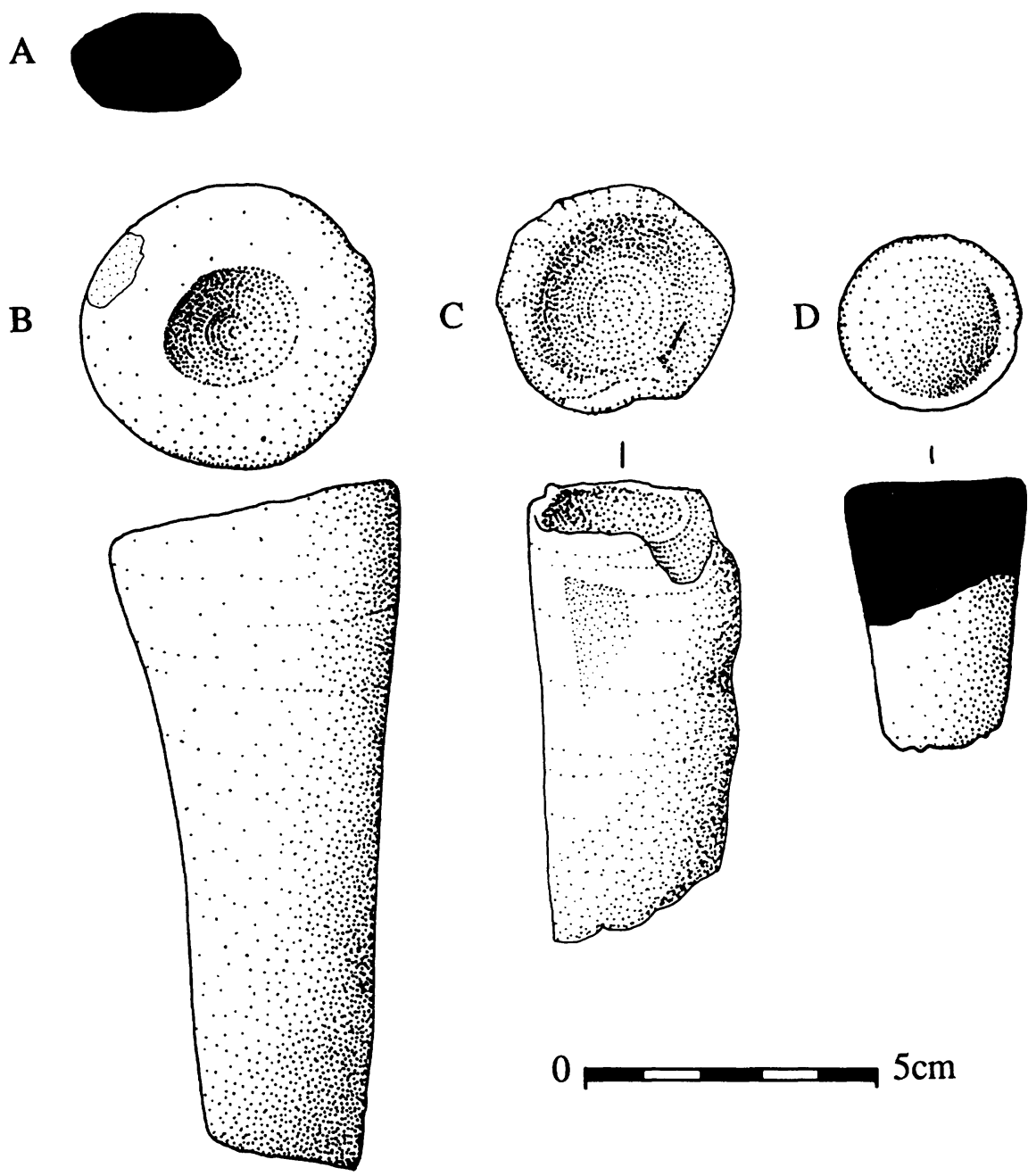

1

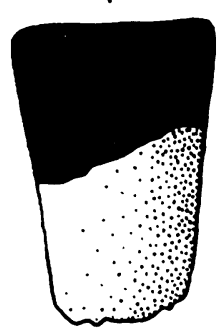

Fig. 8. "Eye idol" HN3302 (A) and Uruk clay wall cones (B-D), operation 1/6, phase B

the bowl/container on the other, a disk.shaped plug of bitumen, and one piece bearing the impressions of parallel wooden beams. This last piece might possibly have been used as waterproofing on a roof or a raft. Bitumen residues were found on 54 sherds. In most cases, these residues apparently reflect the deliberate application of bitumen as a waterproof liner in larger storage jars and in at least one small juglet.
Several lines of evidence also suggest that bitumen was brought to Hacinebi in blocks, and then melted down at the site for specific uses by the in. habitants. The bitumen sample with the impression of a bowl interior on one side and reed mat impressions on the other suggests that the bitumen was stored and/or transported in the form of small blocks in bowls (possibly stacked, with reed matting separating each bowl). The shape and location of the 
bitumen residues on some of the ceramics provide additional evidence for on-site processing of bitumen. In some cases, the bitumen residues are found on the broken surfaces of sherds. The localization of these residues suggests that these are accidental dribbles, rather than the careful application of bitumen as an adhesive to repair a broken vessel. Bitumen residues are also found in nine beveledrim bowls, suggesting that a secondary usage of these vessels might have been to melt down bitumen blocks. In addition, bitumen residues were found localized in the lip spouts of two grit-tempered conical cups, suggesting that these vessels were used to pour out melted bitumen.

Although some natural sources are recorded for this area, ${ }^{32}$ bitumen has rarely if ever been reported from Local Late Chalcolithic sites in southeastern Anatolia. Bitumen sources are common in southern Mesopotamia and the adjacent region of Khuzistan in southwestern Iran, with one of the most widely used seepages at Hit on the Euphrates River ${ }^{33}$ Similarly, bitumen is ubiquitous as a construction material, sealant, and raw material for a variety of functional or decorative objects at Uruk settlements in the south. The Hacinebi data are consistent with the archaeological evidence for the transport, storage, and processing of bitumen at the Mesopotamian site of Abu Salabikh in the Jemdet Nasr period, ${ }^{34}$ and possibly in the Uruk period as well. These clear inter. regional contrasts in bitumen availability and use raise the possibility that this material might have been either a trade good exported from Mesopotamia to southeastern Anatolia, or else the packaging within which some other (as yet unidentified) trade good was transported. In this respect, it may be significant that bitumen has also been found at the Uruk settlement of Habuba Kabira-South, ${ }^{35}$ and at Tell Sheikh Hassan in Syria. ${ }^{36}$ The Hacinebi bitumen samples and residues have been submitted for chemical characterization studies to determine whether or not they derive from Mesopotamian sources. ${ }^{37}$ Preliminary analyses by Jacques Connan (Elf Aquitaine) suggest that the Hacinebi bitumen in oper-

\footnotetext{
${ }^{32}$ R.J. Forbes, Studies in Ancient Technology I (Leiden 1955) $\operatorname{map} 1$.

${ }^{33}$ R. Marschner and H. Wright, "Asphalts from Middle Eastern Archaeological Sites," in G. Carter ed., Archaeological Chemistry II (Washington, D.C. 1977) 150-71; R. Marschner, L. Duffy, and H. Wright, "Asphalts from Ancient Town Sites in Southern Iran," Paléorient 4 (1978) 97-112; Forbes (supra n. 32) 33-40.

${ }^{34}$ S. Pollock, "Political Economy as Viewed from the Garbage Dump: Jemdet Nasr Occupation at the Uruk
}

ations 1 and 6 is similar in chemical composition to the bitumen at Habuba Kabira-South; it is likely that both groups of bitumen samples derive from the Hit source area in Mesopotamia.

Immediately to the west of the platform terrace in operations 1 and 6 at the northeastern corner of the mound, excavations in operation 4 (an $8.5 \times$ $10 \mathrm{~m}$ trench) recovered a series of three wellpreserved Late Chalcolithic building levels dating to the middle and end of phase $B$. The best-preserved of these building levels forms a series of four rooms oriented around a courtyard (fig. 9). The room complex is located to the west of a narrow pebble- and sherd-lined alley running north/northwest-south/ southeast. The earliest of the operation 4 building levels ties in stratigraphically to the Local Late Chalcolithic deposits on the west side of wall 10/45 in operations 1 and 6 . To the east of these rooms is a pebble-paved alleyway running northwest-southeast. The rooms are constructed of $50-60 \mathrm{~cm}$ wide mudbrick walls on stone footings. Generally, the inner surfaces of the walls were plastered with mud or lime, while the outer surfaces were faced with stones to protect them from water damage. Each room appears to have been constructed independently, so that the building level does not represent a single planned complex or public building. Instead, the combination of small rooms, relatively narrow walls, and the presence of trash.filled pits, hearths, and large cooking pots ("casseroles") set into courtyard floors all suggest that this was a residential area. The rooms in this area went through several phases of use and rebuilding. The ceramics from these buildings consist mainly of Local Anatolian Late Chalcolithic types, although Uruk Mesopotamian-style beveledrim bowls are also present. The residential building levels of operation 4 can be stratigraphically linked to those in both operations 1 and 6 , allowing us to reconstruct the architecture of phase $B$ over a broad area in the northeastern part of Hacinebi.

Some of the most important evidence for Uruk Mesopotamian material culture in phase $B$ at Hacinebi was recovered from surface finds in the

\footnotetext{
Mound, Abu Salabikh," Paléorient 16 (1990) 57-75, esp. 70; Susan Pollock, personal communication.

${ }^{35} \mathrm{~J}$. Connan and O. Deschesne, "Le bitume dans l'antiquité," La Recherche 22 (1991) 156.

${ }^{36}$ Johannes Boese, personal communication.

${ }^{37}$ E.g., J. Connan, D. Dessort, and O. Deschesne, "Les bitumes de Tell es Sawwan en Irak: Un modèle d'huiles extrêmement biodegradées et oxidées," Bulletin des Centres de Recherche et Exploration, Production Elf Aquitaine 16 (1992) 33-53.
} 


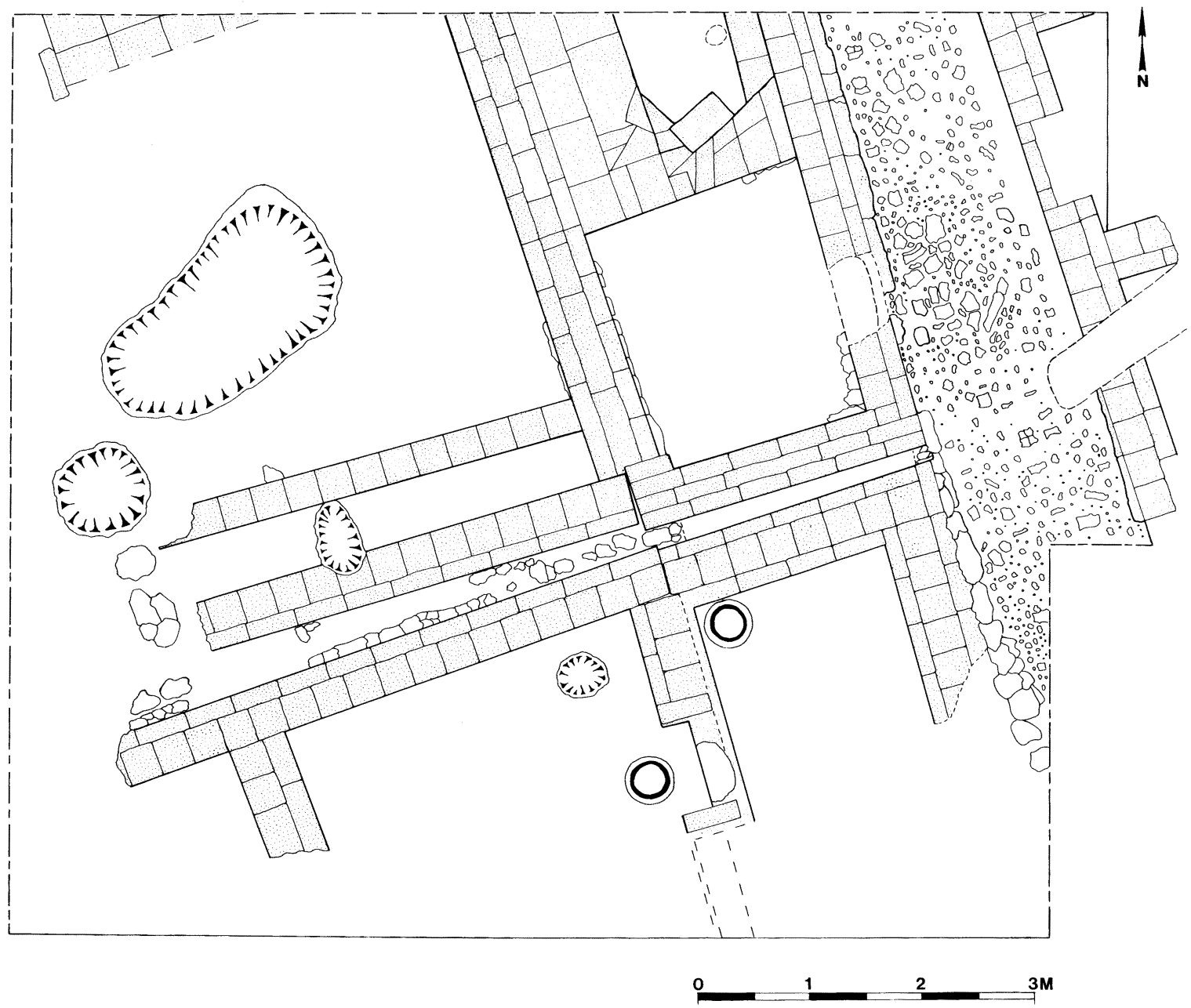

Fig. 9. Operation 4, phase B domestic architecture

northeastern area. In preliminary cleaning of backdirt from the construction of a modern water storage depot in the area adjacent to operation 6 , excavators recovered an Uruk-period bulla filled with tokens and covered with the impressions of two Urukstyle cylinder seals (see Pittman, below). Bullae are common at major Uruk sites such as Uruk/Warka in southern Mesopotamia and are present at the Uruk colony of Habuba Kabira-South in Syria ${ }^{38}$ dur. ing the late fourth millennium, but the Hacinebi bulla is the first and only Uruk bulla found in Turkey to date. The occurrence of a bulla at Hacinebi is highly significant because it provides strong evidence for direct contact between Mesopotamians and Anatolians at the site. The presence of the bulla and tokens, combined with the find of the stamp seal impressions in operation 6 pit 84, demonstrates that both Uruk and Anatolian administrative systems were in use, probably by two culturally distinct groups, living together and engaging in exchange activities at Hacinebi.

This picture of marked variation between two different, contemporaneous cultural traditions is further emphasized by the differences between the northern area, with both Anatolian and Mesopotamian materials, and the southern area of the site, where the phase B deposits are largely local Anatolian in character. Excavations in the southern portion of Hacinebi took place in operations 2 and 7, exposing a contiguous area of ca. $175 \mathrm{~m}^{2}$.

The phase B occupation in operation 2 consists of a large stone structure overlying the trash-filled rooms and eroded mudbrick walls of the phase $A$ structure. The ceramic assemblage associated with this later structure appears to be limited to Local Late Chalcolithic forms, with no evidence of Uruk

${ }^{38}$ Sürenhagen 14 . 

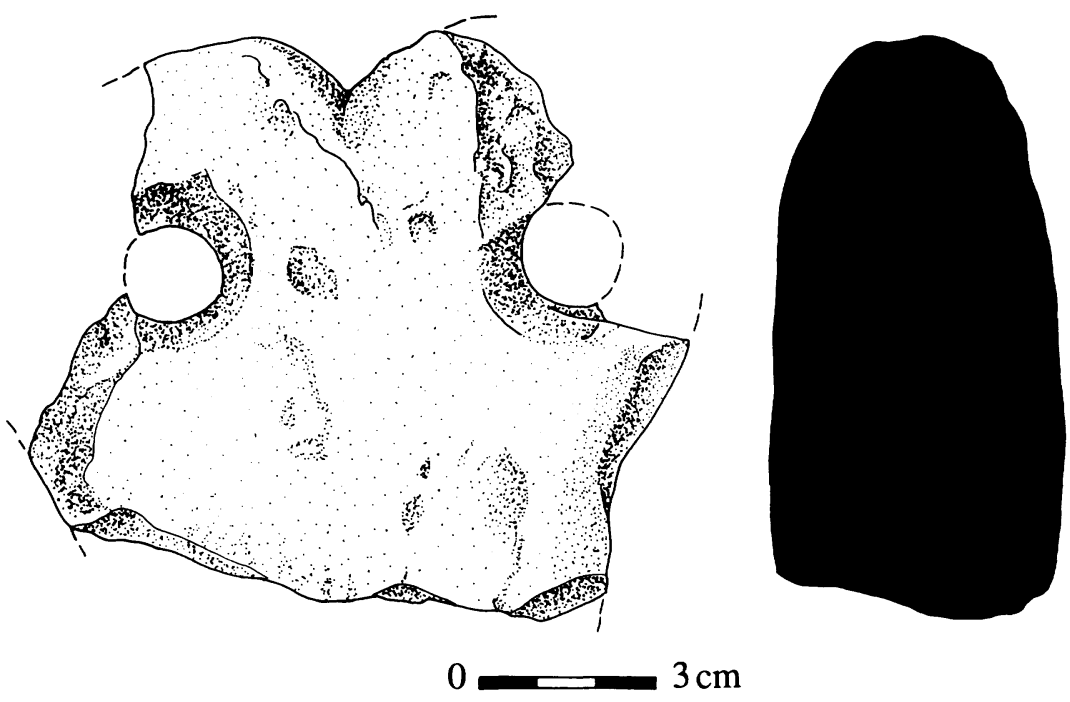

Fig. 10. Limestone "hut symbol" HN3564, operation 7

Mesopotamian ceramics. It is as yet unclear, however, whether the absence of Uruk types in this upper Late Chalcolithic phase indicates a pre-contact date (i.e., a later building episode in phase A), or if instead it dates to phase $\mathrm{B}$, and simply reflects a functional difference within the site, similar to that observed for the two sides of wall 10 in operation 1. Detailed analysis of the ceramics and processing of radiocarbon dates from this occupation phase should clarify whether the operation 2 stone structure belongs to late phase A or to phase B. In an open area immediately adjacent to this structure, a fragment of a stamp-impressed clay sealing was recovered similar to the cache of sealings in operation 6 pit 84 in the north area. The underside of the sealing bears the impression of a small cylinder-either a jar neck or a small knob - along with possible string imprints. Although badly damaged, enough of the obverse is preserved to show the impression of a round stamp seal with a figural decoration.

Excavations in the contiguous $10 \times 10 \mathrm{~m}$ trench, operation 7 , show several distinct stratigraphic sub. divisions during phase B. The earliest-preserved building level in phase $\mathrm{B}$ consists of a partially preserved mudbrick structure oriented northwestsoutheast. This structure is built on top of the eroded massive mudbrick walls of phase A2. The walls of the phase B building are $1.4 \mathrm{~m}$ thick and have unworked stone cobbles as the bottom course along the building's eastern (outside) face. The stones are not visible on the western (internal) face of the wall.

\footnotetext{
39 Frangipane (supra n. 26) fig. 7.1; Tobler (supra n. 22) pl. 86; A. Perkins, The Comparative Archaeology of Early Meso-
}

In this same building, wall 48 was constructed with several small, crudely formed niches and buttresses no more than one brick wide. The thickness of the walls and the presence of niches suggest that this might have been a special-purpose building; however, the structure was badly damaged by subsequent pitting and erosion. In a deposit inside the southeastern room of this niched structure, a carved limestone "hut symbol" was found (fig. 10). Clay and stone hut symbols are known from Local Late Chalcolithic settlements such as Arslantepe VII, Gawra VIII-XII, Grai Resh II-IV, and Hassek Höyük. ${ }^{39}$

The building level above the niched mudbrick building has a large stone structure (26) that may have been the footing for a fortification tower or some other large structure. The area immediately to the south of this stone feature was open and sloped down toward the southern edge of the site. In the wash deposits that postdate the construction of structure 26, one local-style infant jar burial (locus 30) was found, along with several pits containing high concentrations of Uruk ceramics (mainly beveled-rim bowls) with occasional local ceramic types such as "casseroles" and hammerhead bowls. This use pattern suggests that by late in phase $B$, this southern edge of the site was an open area. A final wash layer (25) seals off the pits and represents the end of phase $B$ occupation in the southern portion of the site.

On the western slope of the site, excavations in operation 5 recovered only limited evidence for phase B occupation. The ceramics from the upper

potamia (Chicago 1949) 191; Behm-Blancke 1981 (supra n. 12) pl. 12.5 . 
Table 1. Hacınebi Late Chalcolithic Radiocarbon Dates

\begin{tabular}{lccccccc}
\hline $\begin{array}{l}\text { Beta Analytic } \\
\text { sample no. }\end{array}$ & $\begin{array}{c}\text { HN } \\
\text { no. }\end{array}$ & Op. & Locus & Lot & Phase & $\begin{array}{c}\text { Date B.P. } \\
\text { (uncalib.) }\end{array}$ & $\begin{array}{c}\text { Date B.C. } \\
(\text { calib.) }\end{array}$ \\
\hline 67912 & 1129 & 1 & 94 & 107 & A & $4210 \pm 200$ & $3035-2487$ \\
67913 & 1447 & 2 & 59 & 110 & A & $4890 \pm 180$ & $3817-3504$ \\
67914 & 2049 & 5 & 62 & 106 & A & $4600 \pm 200$ & $3534-3078$ \\
67916 & 3221 & 4 & 53 & 153 & B & $4810 \pm 90$ & $3693-3507$ \\
67917 & 3582 & 7 & 50 & 86 & B & $5060 \pm 130$ & $3973-3709$ \\
67919 & 4000 & 4 & 97 & 220 & B & $4660 \pm 80$ & $3527-3345$ \\
\hline
\end{tabular}

* Calibrated radiocarbon dates are presented as a range of one standard deviation around the highest probability intercept point along the dendro-calibration curve.

building levels of operation 5 are almost entirely Local Late Chalcolithic chaff-tempered wares, with only occasional Uruk types such as beveled-rim bowls present in pits.

Overall, there is clear evidence for intrasite variation in architecture and function at Hacınebi during phase $\mathrm{B}$. The northern area is characterized by high concentrations of both Uruk and local Anatolian ceramics, administrative artifacts, and other material culture in adjacent but distinct contexts. By contrast, Local Late Chalcolithic material culture predominates in the southern area of the site, which seems to have been used as an area for public, possibly ritual, buildings.

The stratigraphic sequences of each area also show that this heterogeneous site organization changed markedly over the course of the contact phase. In the northern area, there appears to have been a progressive shift from planned, stone architecture toward smaller-scale, mudbrick room complexes that grew by accretion; these latest-preserved building levels are clearly a group of small house rooms. In the southern part of the site, the public buildings pass out of use long before the end of phase $B$; the resulting open area was then used for jar burials and trash pits. On the western slope of the site, the latestpreserved phase B occupation also appears to be an open area with trash pits, although this apparent shift in use may be due to either fewer people living on that part of the site or to sampling problems due to the limited area excavated. Broader horizontal exposures on the western slope are needed to clarify this problem. On balance, however, the currently available evidence suggests that the size or density of settlement at Hacınebi may have declined over the course of phase $B$. It is difficult to determine whether or not this trend was related to some aspect of the Uruk expansion, since high concentrations of

\footnotetext{
${ }^{40}$ M. Stuiver and P. Reimer, "University of Washington Quaternary Isotope Lab Radiocarbon Calibration Program
}

Uruk ceramics are present both at the beginning of phase B, and in the very late pits as well.

Finally, we know very little about how or why phase $\mathrm{B}$ at Hacinebi came to an end. In the northern area, where settlement appears to have been densest, the uppermost building levels of the phase have been truncated by later Achaemenid/Hellenistic architecture. There are no signs of violent destruction in any part of the site during either phase A or B. Given the apparent shifts toward simpler architecture and shrinkage in site size, the most reasonable interpretation of the available evidence is that Hacinebi was peacefully abandoned in the late fourth millennium.

\section{LATE CHALCOLITHIC CHRONOLOGY}

A total of 114 radiocarbon samples were collected from both Achaemenid/Hellenistic and Late Chal. colithic contexts at Hacınebi during the 1992-1993 field seasons. Of these, six samples have been analyzed to date: three each from phases A and B (table 1). The samples were processed by Beta Analytic laboratories; the resultant dates were calibrated using the CALIB 3.0.3A calibration program. ${ }^{40}$ The dates show a high degree of variability and should be viewed with caution until more samples are dated from the two phases. Of the phase A samples, beta67912 appears to be suspiciously recent, and is prob. ably unreliable. The three calibrated phase $B$ radio. carbon dates (beta-67916, 67917,67919) all fall in the mid-fourth millennium and are consistent with Pol. lock and Coursey's suggestion of a late Middle Uruk date for at least part of the phase B ceramic assemblage (see below). The earlier dating is also consistent with the typological characteristics and radiocarbon dates for the ceramics from the Middle Uruk levels at Tell Sheikh Hassan in the Tabqa dam area of the Syrian Euphrates.

These new dates supersede the Late Uruk date

Rev. 3.0.3A," Radiocarbon 35 (1993) 215-30. 
Table 2. Late Chalcolithic Relative Chronology

\begin{tabular}{llccccc}
\hline Date & & Atatürk Dam & & Tabqa Dam & Southern \\
B.C. & Hacinebi & Kurban & Reservoir & Arslantepe Amuq & Leilan & $\begin{array}{c}\text { Reservoir } \\
\text { Mesopotamia }\end{array}$ \\
\hline
\end{tabular}

3000

3500

?

\author{
VIA
}

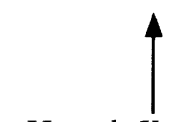

Hassek Karatut

(

VIB

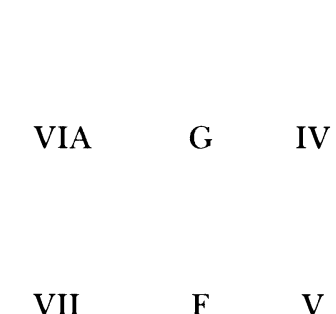

VII
Habuba Kabira
Jebel Aruda

V

$\mathrm{F}$

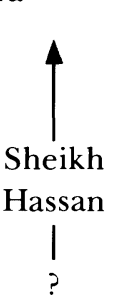

Late Uruk

Middle Uruk

A

initially proposed for Hacinebi phase B in the preliminary report on the 1992 season, ${ }^{41}$ although it should be noted that we have not yet dated the end of phase B at Hacinebi (table 2). The clear ceramic parallels with Kurban VI-A, Brak, Leilan IV (generally seen as Late Uruk), and Karatut Mevkii (dated to Late Uruk/Jemdet Nasr) suggest that the Hacınebi phase B might well have lasted for several centuries, extending from the Middle Uruk into the beginning of the Late Uruk time period in terms of southern Mesopotamian chronology. Additional support for the continuation of Hacinebi phase B into the Late Uruk derives from the observation that the closest stratigraphic parallels to the Uruk cylinder-seal impressed clay ball/bulla are from levels $17 \mathrm{~b}-18$ at Susa, corresponding to the Late Uruk period.

If the radiocarbon dates are correct, this would suggest that the period of Uruk contact with Anatolia began in the Middle Uruk at sites such as Sheikh Hassan, Hacinebi, and possibly Brak, ${ }^{42}$ and then continued into the Late Uruk at sites such as Habuba Kabira-South, Jebel Aruda, and Hassek Höyük. In other words, rather than being a short-lived episode, the Uruk expansion might possibly have lasted 500600 years in the upper Euphrates area. This would then push back phase A at Hacinebi into the early part of the fourth millennium, perhaps as early as 3900-3700 B.C.

It is important to reemphasize that these dates for the two Late Chalcolithic occupations at Hacinebi are highly tentative. An overreliance on Mesopotamian ceramic parallels (often from limited deep soundings in the south) extended over long distances into the indigenous cultures of Anatolia and north-

${ }^{41}$ Stein and Misir.

42 D. Oates and J. Oates, "Excavations at Tell Brak ern Syria can lead to serious errors in the way we construct regional chronologies (and thus our reconstructions of regional patterns). Ultimately, we need to put together a synthetic chronology that in. tegrates southern Mesopotamian ceramics, radiocarbon dates from both "local" and "Mesopotamian. related" sites, and detailed chronologies for the local ceramics of southeastern Anatolia and northern Syria.

\section{CONCLUSIONS}

The discovery at Hacınebi of an occupational se. quence with both pre-contact and contact phases provides a rare opportunity to study the ways in which the expansion of Uruk Mesopotamia affected the social, political, and economic development of its resource-rich neighbors in the fourth millennium. Several lines of evidence suggest that existing models of the Uruk expansion may have underestimated the role of Local Late Chalcolithic cultures in this process.

The fortification wall, large-scale public architecture, and associated evidence for long-distance exchange of chlorite ornaments in Hacınebi phase A raise the possibility that the pre-contact societies of southeastern Anatolia might have been more complex than is generally recognized. The limited available data suggest a high degree of variability in the economic and political systems of Late Chalcolithic (fourth-millennium) southeastern Anatolia. Evidence for metallurgy and ceramic mass production at Arslantepe suggests that local highland communities had already begun to develop a fairly complex, specialized economic organization in period VII,

1992-93," Iraq 55 (1993) 155-99. 
before the Uruk expansion. ${ }^{43}$ The phase A data from Hacinebi are consistent with the evidence from Arslantepe VII in suggesting the beginnings of social complexity in the Taurus piedmont as well during the early fourth millennium.

Excavations in the phase B occupation of Hacinebi have shown a high degree of intrasite variability in architecture and lithic and ceramic distributions during the period of interaction with Uruk Mesopotamia. The southern and western areas of the phase B settlement have predominantly Local Late Chalcolithic material culture. In the south area (op. 2, 7), finds of a large stone structure, an Anatolianstyle stamp seal impression, and a carved limestone "hut symbol" in association with a mostly local chafftempered ceramic assemblage suggest some kind of special function for this part of the site. Preliminary analyses of both the chipped stone tools and ceramics show clear differences in the manufacture and use of ceramics and stone tools among these different parts of the phase B settlement.

In stark contrast to the local character of the south slope, Uruk material is highly localized within the northeastern area of the phase B settlement. Uruk and Local Anatolian Late Chalcolithic material cul. ture often occur separately in contemporaneous contexts. The bitumen objects and residues from the northern area may be the first direct evidence for Mesopotamian trade goods present in an Anatolian settlement. These clear differences in the distribution of Mesopotamian and local artifacts at Hacinebi may simply reflect some form of functional variation, or a process in which local elites emulated Mesopotamian styles of material culture. ${ }^{44}$ However, the concentration of Mesopotamian ceramics, architectural ornaments, administrative paraphernalia, and other artifacts is consistent with the criteria proposed by Sürenhagen ${ }^{45}$ for the identification of a "genuine" Uruk settlement. On balance, the evidence suggests the presence of a small group of Uruk traders in the northern area of Hacinebi. Although they seem to have lived as a spatially and culturally distinct group, there is no evidence to suggest that the Mesopotamians dominated the local community in either political or economic terms. Instead, the use of both Mesopotamian and Anatolian forms of administrative (sealing) technology suggests that each group had at least some control over the circulation of goods in the exchange system. The presence of Urukstyle kiln wasters, along with the faunal and lithic evidence (see below), all suggest that the makers and users of the Uruk material culture at Hacinebi were an autonomous group that raised its own animals, knapped its own flint tools, and manufactured its own ceramics alongside the local Anatolian host community. Thus, if one were looking for a modern analogy, the Mesopotamians at Hacınebi may have resembled a trade diaspora rather than a group of colonial masters.

It seems increasingly likely that a small number of Mesopotamians lived as a distinct community among the local Anatolian population and engaged in exchange with them during phase $B$. If this is the case, then the Hacınebi data provide an almost unique opportunity to examine both the nature of interaction between Middle/Late Uruk Mesopotamia and its neighbors and the effects of this contact on Anatolian society during the fourth millennium.

\author{
DEPARTMENT OF ANTHROPOLOGY \\ NORTHWESTERN UNIVERSITY \\ 1810 HINMAN AVENUE \\ EVANSTON, ILLINOIS 60208 \\ G_STEIN@CASBAH.ACNS.NWU.EDU
}

MÜZE MÜDÜRLÜĞ̈̈

ŞANLIURFA MÜZESI

ŞANLIURFA

TURKEY

\section{THE ACHAEMENID-HELLENISTIC OCCUPATION AT HACINEBI}

\section{Augusta McMahon}

Hacınebi Tepe lies between Birecik, the modernday east-west crossing point of the Euphrates, and

\footnotetext{
${ }^{43}$ Palmieri (supra n. 7) 196-202; A. Palmieri, "Storage and Distribution at Arslantepe-Malatya in the Late Uruk Period," in K. Emre et al. eds., Anatolia and the Ancient Near East: Studies in Honor of Tahsin Özgüç (Ankara 1989) 419-30; Frangipane and Palmieri (supra n. 5) 299.
}

the ruins of Zeugma/Apamea, an important crossing point of the Hellenistic/Roman period. During the

\footnotetext{
${ }^{44}$ G. Stein, "Ethnicity, Exchange, and Emulation: Mesopotamian-Anatolian Interaction at Hacinebi, Turkey," paper presented at the 59th Annual Meeting of the Society for American Archaeology, Anaheim, Calif. 1994.

45 Sürenhagen 9-10.
} 
Seleucid period, following the death of Alexander the Great, Hacinebi was at or near the boundary of the provinces of Mesopotamia on the eastern bank of the river and Cappadocia on the west. Subsequently, for much of the duration of Roman control of the area, the site was near the border between the Roman province of Cappadocia and the semiindependent kingdom of Commagene.

The first two seasons of excavation at Hacinebi uncovered substantial Achaemenid to Hellenistic, or late first-millennium B.C., remains: parts of two monumental buildings and a number of ovens, pits, and other domestic installations. First-millennium levels were exposed in operations 2-4 and 6-9, which have a horizontal extent of 80 (north-south) $\times 55$ (east-west) $\mathrm{m}$. Surface distributions of Hellenistic ceramics extend an additional $45 \mathrm{~m}$ to the west, sug. gesting that the site probably ranged from 0.4 to 0.8 ha in this period.

\section{CHRONOLOGY OF THE LATE}

\section{FIRST-MILLENNIUM B.C. OCCUPATION}

There is not a complete occupational sequence at the site for the several centuries covered by the term "Achaemenid/Hellenistic"; a number of distinct stratigraphic phases, however, are represented within the late material. The earliest material exposed belonging to the first-millennium occupation is a grave in operation 7 containing jewelry and other items datable to the fifth century B.C. Occupation levels from this time may be represented in operations 8 and 9 , but further study of the pottery from these areas is needed before any correlation can be made. A monumental building over the grave in operation 7 is judged to be approximately contemporary with a similar building in operation 4; unfortunately, the deposits in both buildings were very clean and contained few artifacts useful for dating. Both buildings were cut by a number of large pits, in one of which a bronze coin of Alexander the Great was found (op. 4, locus 13). The pottery from these pits dates to the third to second centuries B.C. Thus, we judge the buildings in operations 4 and 7 to be approximately fourth century B.C. in date.

\section{GEOPHYSICAL PROSPECTION}

Some indication of the nature and layout of the Achaemenid-Hellenistic occupation at Hacınebi was gained from a test program of geophysical prospection conducted in 1993 by Lewis Somers of GeoScan Research USA. Two techniques, magnetometry and soil resistivity mapping, were used to detect and map architecture and other man-made features in the uppermost strata beneath the surface of the mound.
Magnetic and resistivity measurements were made in $2620 \times 20 \mathrm{~m}$ units in the central portion of the site, or a total area of $10,400 \mathrm{~m}^{2}$. This comprises a $31 \%$ sample of the total surface area of Hacinebi. Separate maps were made for resistivity data at depths of $1 \mathrm{~m}$ and $2 \mathrm{~m}$ below modern ground surface of the site (fig. 11); the dark portions of these maps indicate areas of high resistivity, which may be stone walls. The depth of 1 or $2 \mathrm{~m}$ estimated for these possible structures accords with the depth of the excavated Hellenistic remains, which ranges from 1 to $2.5 \mathrm{~m}$. These dark areas form several large, roughly rectangular areas with linear alignments oriented northeast-southwest. These alignments match the orientation of the massive Hellenistic walls in operations 4 and 7 (see below). Two long narrow trenches, operations 8 and 9, were excavated in areas where the resistivity and magnetometry data sug. gested that large stone walls or kilns might be pres. ent (see below).

The initial results at Hacinebi suggest that mag. netometry and resistivity mapping can be extremely useful techniques for locating buried architecture when the area surveyed has relatively simple stratig. raphy, involving only one major occupation level. In addition, a resistivity survey can be quite effective in detecting stone architecture but appears to be less effective in locating mudbrick walls (since there is virtually no resistivity differential between mudbricks and the surrounding soil). The fairly consistent use of stone foundations for the large Hellenistic mudbrick walls at Hacınebi means that remote sensing can have considerable utility in delineating the broad outlines of the uppermost Hellenistic building levels. The preliminary data suggest that the latest Hellenistic architecture may have consisted of a series of large rectangular courtyard complexes at the eastern end of the site, with smaller domestic structures and possibly more open areas to the west.

\section{EXCAVATIONS IN 1992-1993}

Excavated exposures of Achaemenid-Hellenistic deposits are limited to the eastern third of the site (although the remote sensing and surface collections of ceramics suggest that the settlement extended at least another $50 \mathrm{~m}$ westward toward the Euphrates). Achaemenid-Hellenistic remains were encountered in operations 4 and 6 in the northeastern part of the site, and in operations 2 and 7 in the southeast. Additional soundings in operations 3, 8, and 9 recovered remains from these periods in the central portion of the mound.

In the northeast, a single rectangular room, part of a larger structure, was uncovered in operation 4 


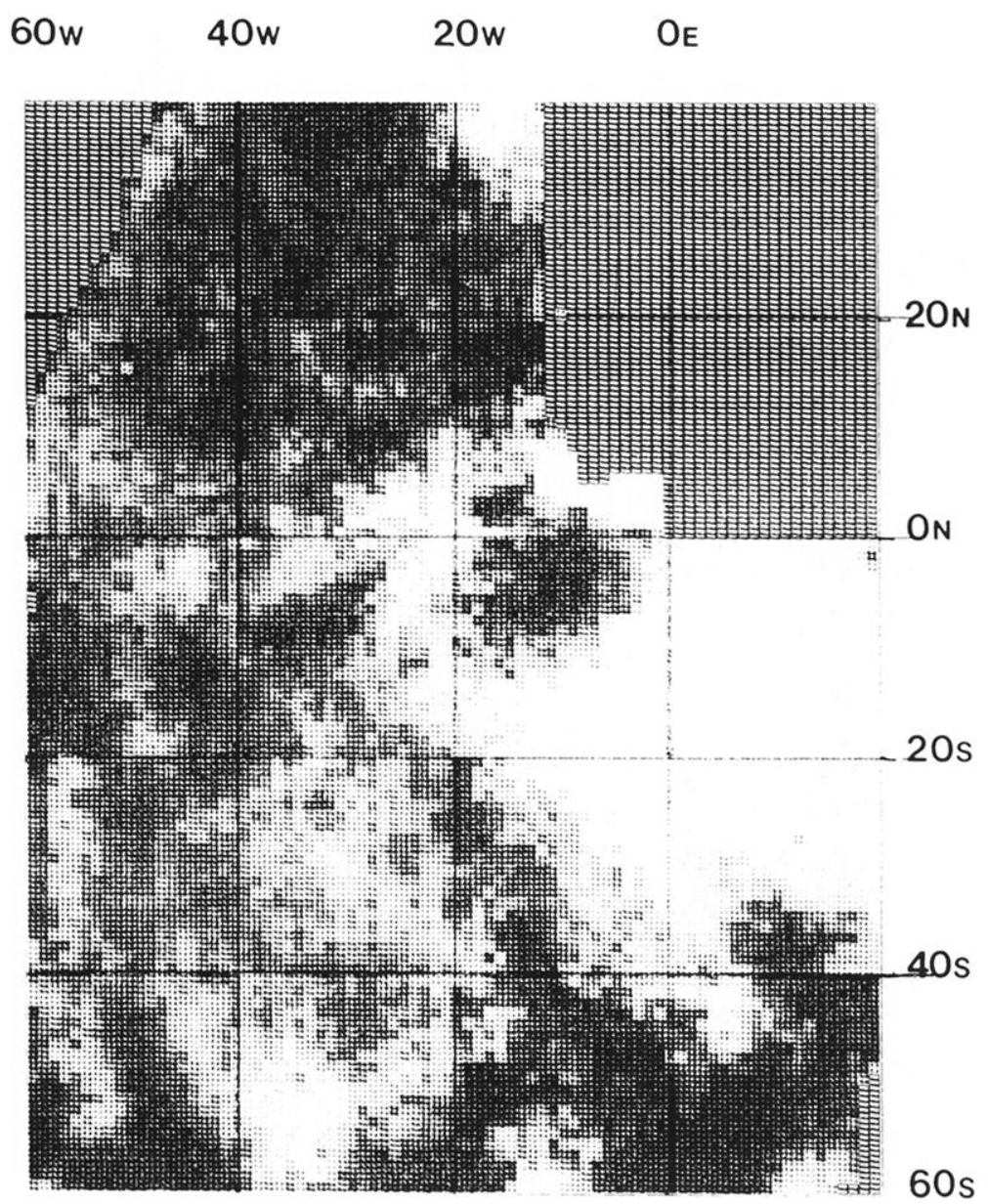

Fig. 11. Enhanced resistivity map, monitoring $2 \mathrm{~m}$ below ground surface. Dark areas indicate high resistivity (possible stone architecture). Note large enclosed rectangular areas, oriented northeast-southwest.

(fig. 12). The walls of the room were built of mudbricks on stone foundations; the foundations were set in trenches that cut into occupational deposits of the fourth millennium. The eastern and western walls of the room were the first to be built, after which the northern and southern walls of the room were built abutting them. The walls were $1.6-2.4 \mathrm{~m}$ wide and constructed of mudbricks in two sizes: $34-40$ $\mathrm{cm}^{2} \times 14 \mathrm{~cm}$ high, and $17-20 \mathrm{~cm}^{2} \times 14 \mathrm{~cm}$ high; the brick faces had been plastered over. The room measured at least $6.5 \times 3 \mathrm{~m}$ and was entered by a wide doorway through the west wall. The plastered floor within the room was clean, and the deposit immediately above the floor also contained few artifacts; it is probable that at least part of the room was deliberately filled. The final deposit in the room was mudbrick wall collapse mixed with trash. The size of the room and the thickness of its walls make it clear that this was a public building, but in the absence of associated artifacts its purpose remains obscure. Although its continuation to the east was eroded, it is probable that this building was located at or near the eastern edge of the site, suggesting that it may have been part of a fortification system.

The eroded remains of the massive foundations of a Hellenistic building were exposed in operation 6 . Like those of operation 4 , the foundations were set in trenches cut into Chalcolithic levels, and the walls were up to $2.3 \mathrm{~m}$ wide. Portions of two rectangular rooms were exposed in operation 6 , with a doorway providing access between them. Clean floors were preserved in both rooms and the deposit above those floors contained few artifacts. Their proximity to the building in operation 4 makes it likely that the two structures exposed were part of the same complex, if not actually parts of the same building. Operation 3 also showed signs of a deep Hellenistic occupation with numerous pits cut into the underlying Late Chalcolithic layers. The uppermost well-preserved Late Chalcolithic deposits were found at approximately $1.5 \mathrm{~m}$ below the modern surface.

At the southern end of the site, in operations 2 


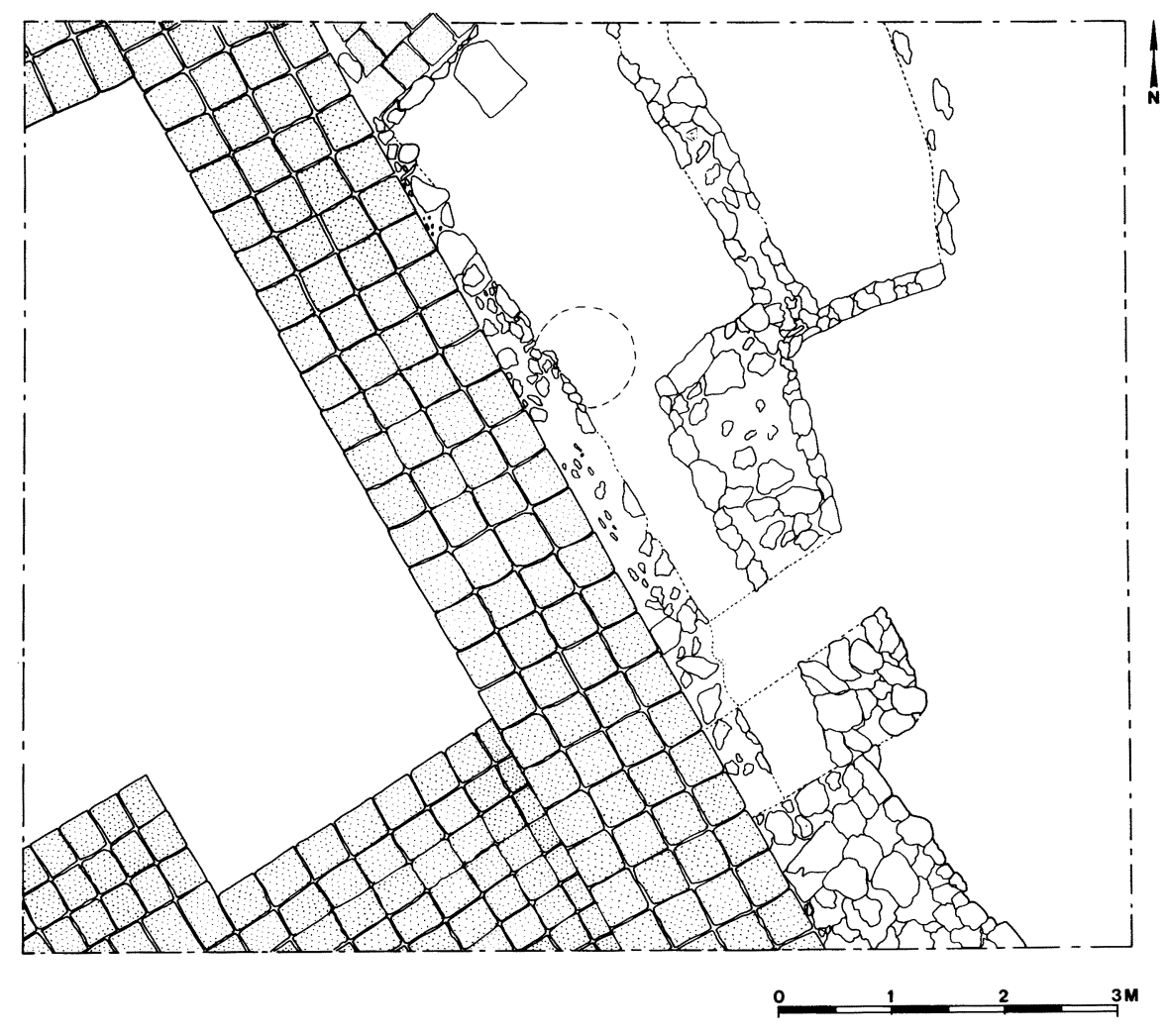

Fig. 12. Operation 4, Hellenistic mudbrick public building

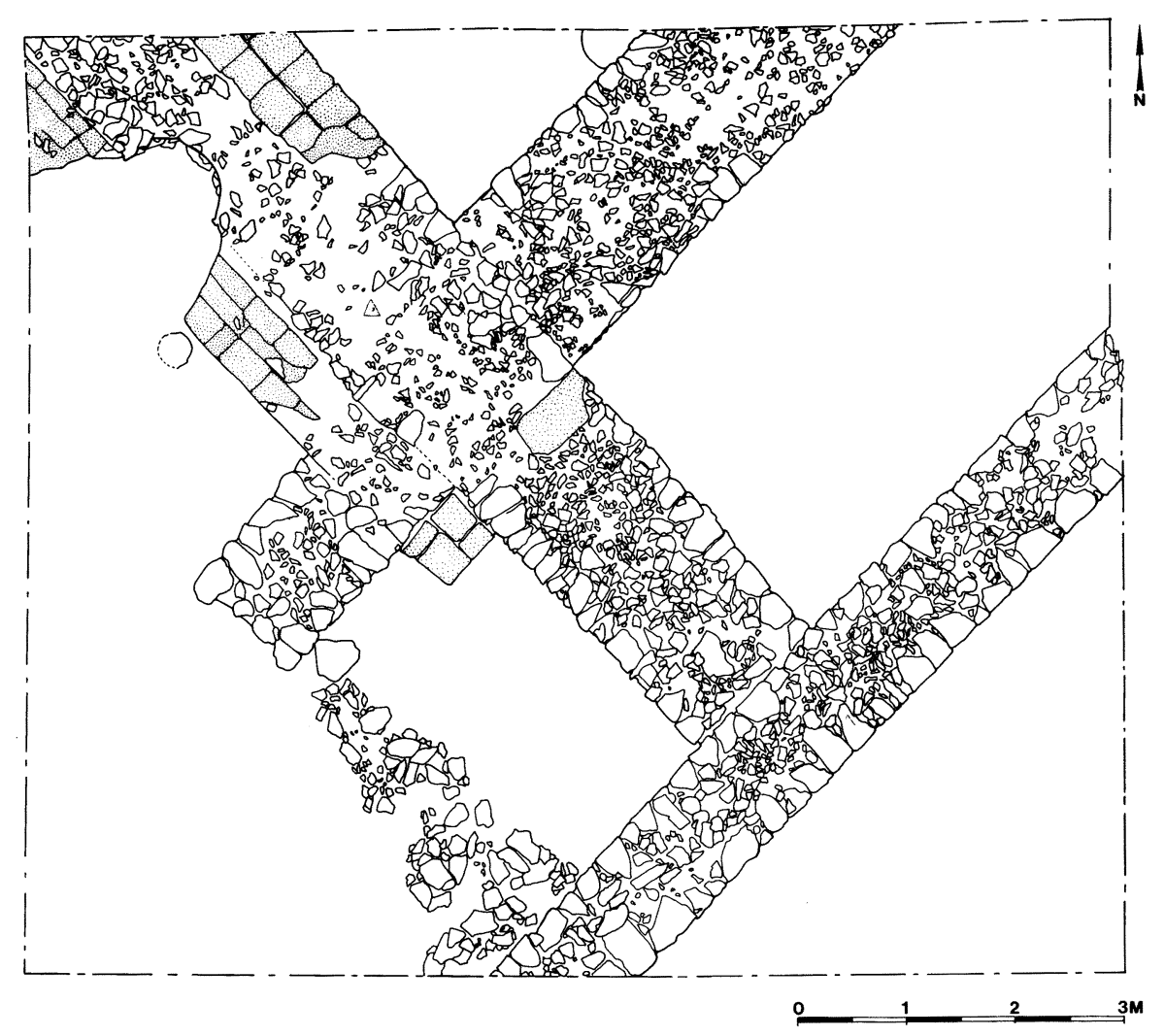

Fig. 13. Operation 2/7, Hellenistic public building 


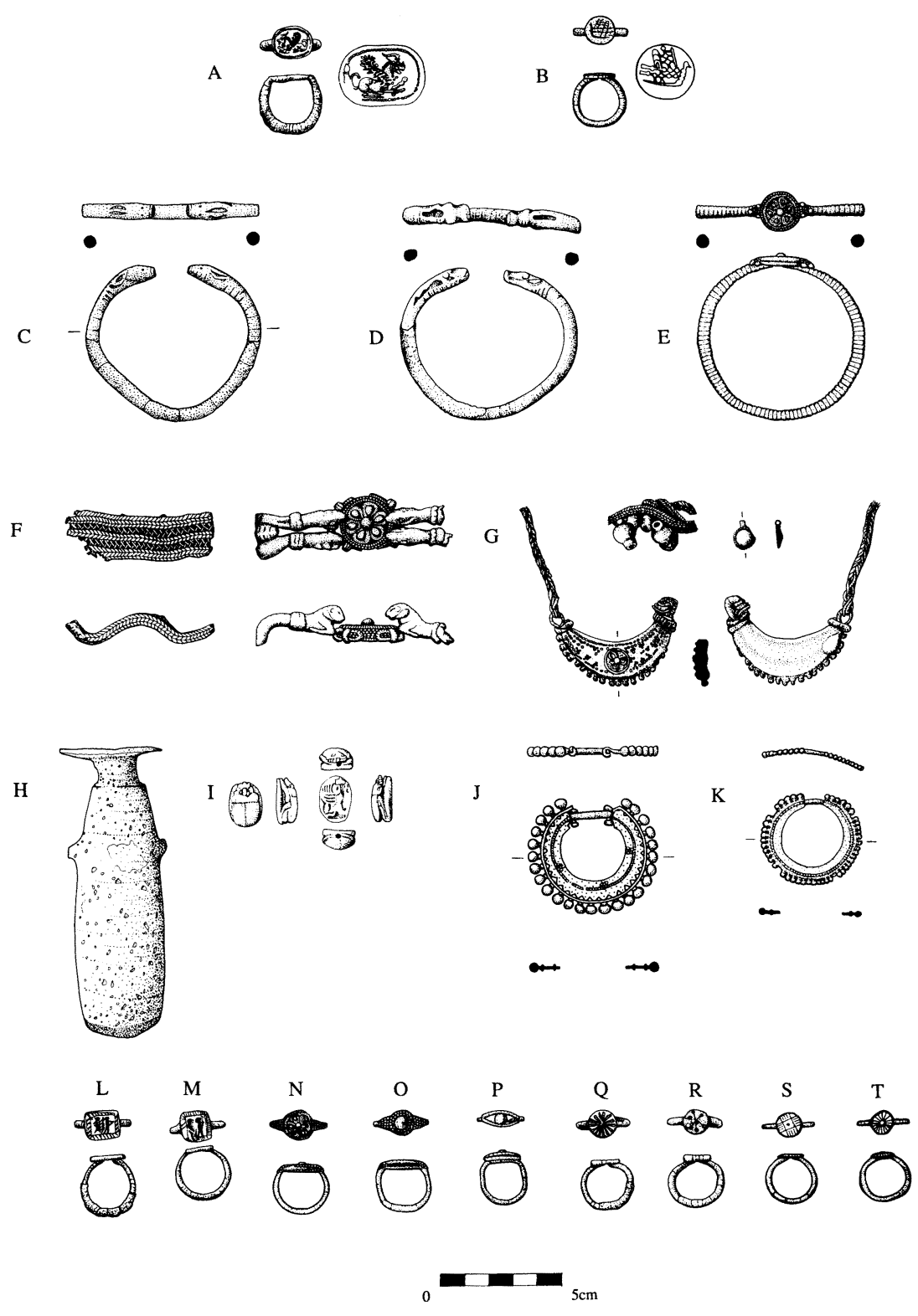

Fig. 14. Jewelry and other small finds from Achaemenid tomb 28, operation 7: A. HN2294.1, silver signet ring with winged lion: cf. L. Legrain, Seal Cylinders. Ur Excavations X (London 1951) pl. 41, esp. 776-96 (Persian-period seal impressions recovered from a coffin at Ur, dated to between 450 B.C. and the first quarter of the fourth century B.C.); Legrain, The Culture of the Babylonians from Their Seals in the Collections of the Museum (Philadelphia 1925) pls. 37.828, 38.852, and 39.853-62 (seated dragon/griffins, Murashu Archive from Nippur, 454-404 B.C.); E. Schmidt, Persepolis II: Contents of the Treasury and Other Discoveries (Chicago 1957) pl. 14: seal no. 69 (Persepolis Treasury Tablets, dated to 492-459 B.C.). B. HN2291.2, silver signet ring with possible ship (?). C. HN2293, silver penannular bracelet with animal heads: cf. Deve Hüyük fig. 11: esp. 265-80, fig. 12.282-85 ("calf-head terminals"); A. Pope, A Survey of Persian Art from Prehistoric Times to the Present VII (Tehran 1977) pls. 121B, D, 122E; D. Stronach, Pasargadae (Oxford 1978) 210: 1, 2 and pl. 160c ("snake head terminals"). D. HN2279.1, silver penannular bracelet with animal heads. E. HN2279.2, silver bracelet with rosette. F. HN2274, silver chain bracelet with rosette and lions. G. HN2276, silver chain necklace with granulation on crescent. H. HN2298, alabastron: cf. Deve Hüyük fig. 8.142; Schmidt (supra) pl. 65.1, 12; two slightly larger alabastrons were found in an Achaemenid tomb on the Susa Acropole: P. Harper, J. Aruz, and F. Tallon eds., The Royal City of Susa, Ancient Near Eastern Treasures in the Louvre (New York 1992$)$ no. 180. I. HN3013, scaraboid stamp seal with griffin: cf. Schmidt (supra) pl. 17: PT7 67. J. HN2282.1, silver earring: cf. Deve Hüyük fig. 13.300; Schmidt (supra) pl. 45.27 (Treasury Courtyard); for similarly shaped earrings inlaid with enamel, see Harper et al. (supra) no. 178 (Achaemenid tomb, Susa Acropole). K. HN2282.2, silver earring. L. HN2294.2, silver ring. M. HN2291.4c, silver ring. N. HN2275, silver ring with rosette. O. HN2277.1, silver ring. P. HN2291.4b, silver ring. Q. HN2291.1, silver ring. R. HN2291.4a, bronze ring. S. HN2277.1, silver ring. T. HN2294.3, silver ring. 


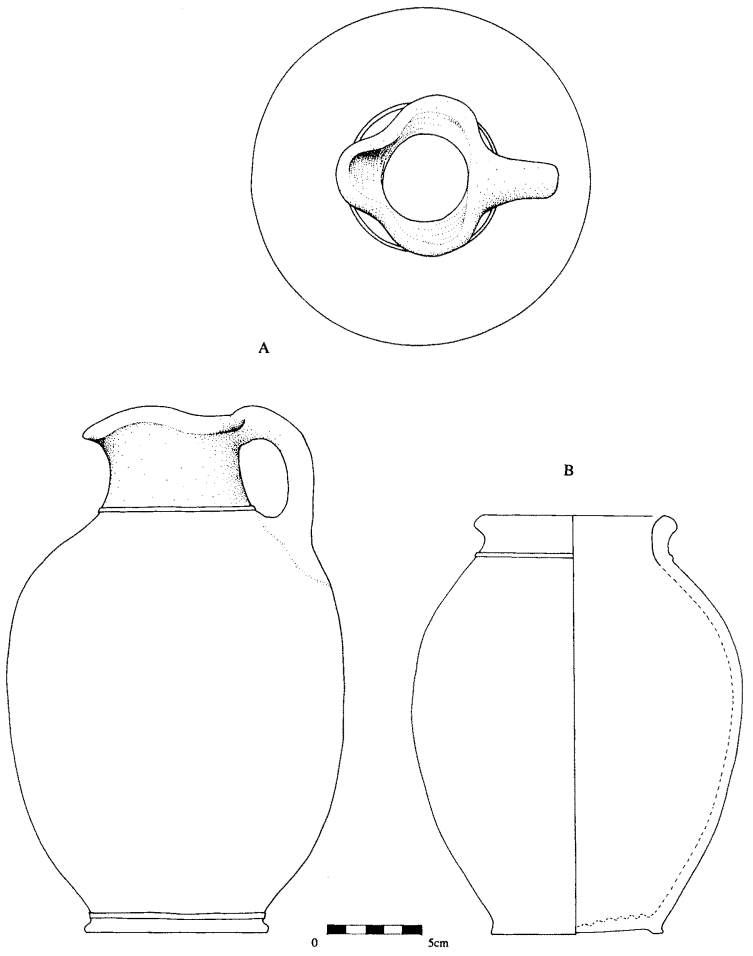

Fig. 15. Complete ceramic vessels from Achaemenid tomb 28, operation 7: A. HN2264, trefoil-mouthed pitcher; B. HN2265, storage jar

and 7 , three rooms of another massive structure of the Hellenistic period were uncovered (fig. 13). Only a portion of the building was recovered - two rectangular rooms adjacent to each other and a smaller, square "porch" at the southwest end of the southern of these. Of the two larger rooms, neither was completely exposed, but one measured at least $3 \times 5.5$ $\mathrm{m}$. The walls of this building were preserved only as high as the stone foundations, which were up to $1.7 \mathrm{~m}$ wide and up to ca. $1 \mathrm{~m}$ high, with roughly worked stone faces confining rubble cores. Floors were not evident, however, and the coarse homogeneous material within the rooms had the appearance of deliberate fill. Today, the road giving access to both the site of Hacinebi and the modern adjacent village runs just below operations 2 and 7 , along the southern edge of the mound. Recent bulldozing of the road has cut into the ancient occupational material here; while the modern improvements make it impossible to identify any ancient road or path in this location, it is likely that this area was also the means of access from the river plain in the past.

\footnotetext{
${ }^{46}$ See Deve Hüyük for full description.

${ }^{47}$ Deve Hüyük fig. 15.385-88. Kohl tubes: fig 15.389-91.

${ }^{48}$ Deve Hüyük fig. 14.384.
}

To the north and west of the site, the sides of the rock formation on which the site sits are a great deal steeper than that on the south. It may be that the operation 2/7 building overlooked or guarded the contemporary access road into the town. A number of pits, also of the late first millennium, subsequently were cut into this building and into the structures in operations 4 and 6 .

Within operation 7, the Hellenistic building overlay an unrelated grave of the Achaemenid or Early Hellenistic period. The grave is remarkably similar to a number of tombs found in a "cemetery" on Deve Hüyük, near Carchemish. ${ }^{46}$ Associated coins and imported Greek pottery date the Deve Hüyük graves to $480-380$ B.C. The pit for the interment was a fairly shallow rectangle, oriented approximately northeastsouthwest, enclosing a mudbrick- and stone-lined rectangular tomb. The long wall along the northwest and the short wall at the northeast were of square mudbricks, while the southeastern wall was constructed of unworked stones. The opening to the tomb was at the southwestern end and had been sealed with a thin slab of stone, set vertically. Several thicker worked stone slabs formed the roof; they had collapsed into the interior. The tomb contained the skeleton of an adult, extended on its right side, with the head to the northeast. The body had been decorated with four silver bracelets; 13 rings of silver, copper and bronze; silver earrings; and two necklaces, one of silver chain with a number of regularly spaced circular pendants, the other of copper, carnelian, and frit beads (fig. 14). A bronze omphalos bowl was placed near the body; and at the head was a group of objects including a bronze mirror ${ }^{47}$ and pin, several bronze arrowheads, an engraved bone tube or handle, ${ }^{48}$ bronze tweezers, ${ }^{49}$ a necklace of carnelian and glass beads, a faience scarab (fig. 14: I), and a small Egyptian alabastron (fig. 14: H). Within the burial pit, but standing outside the slab sealing the tomb, were two pottery vessels, one a trefoil-mouthed pitcher (fig. 15: A), the other a simpler storage jar (fig. 15: B). The jewelry, in particular a signet ring with a winged lion motif (fig. 14: A), dates the grave to approximately the fifth century B.C. The tomb was partially covered by a wall of the Hellenistic building in operation 7 , implying that the location of the burial had already been forgotten or was deliberately ignored when that building was constructed. The range of objects included at Hacinebi is very

${ }^{49}$ Cf. E. Schmidt, Persepolis II: Contents of the Treasury and Other Discoveries (Chicago 1957) pl. 71.6-7. 


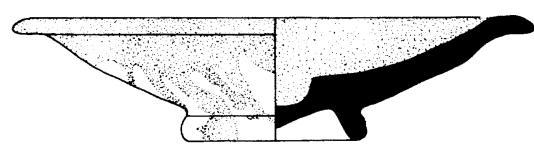

C

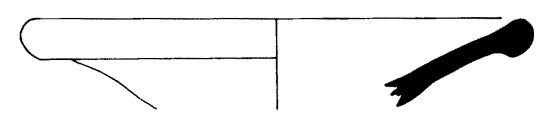

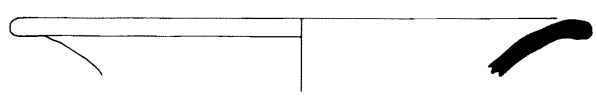

D

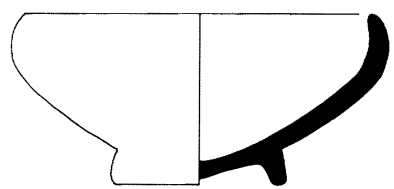

F

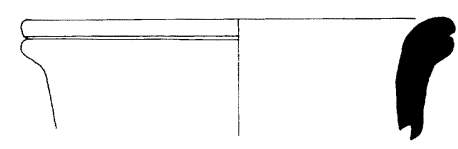

E

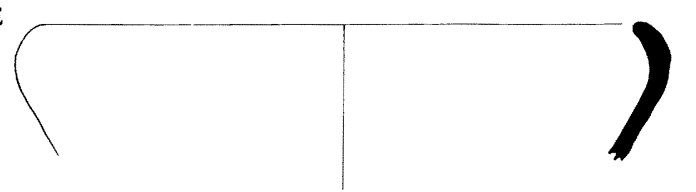

G

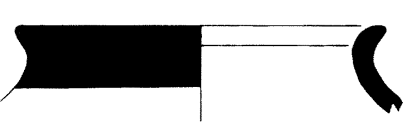

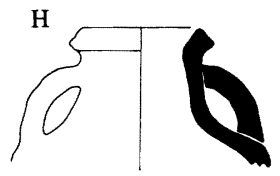

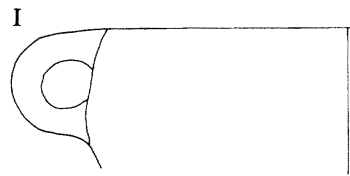

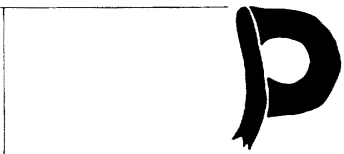

L

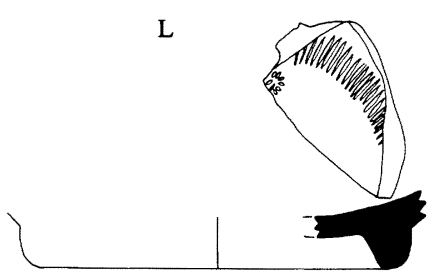

J

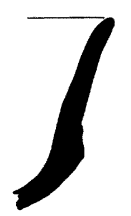

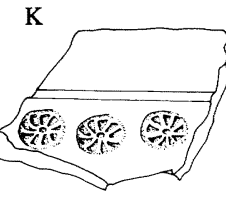

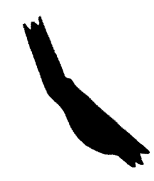

$\mathrm{N}$
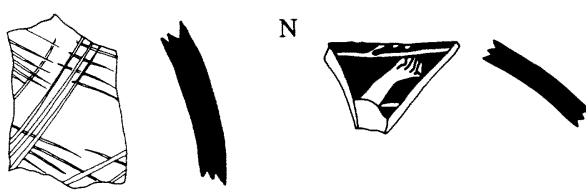

0

$5 \mathrm{~cm}$

Fig. 16. Hellenistic ceramics: A. Dr. no. 93.101, HN1263, op. 4, loc. 12, lot 21, "fish plate": cf. Hama fig. 1.6; Tarsus fig. 120.26-27; S. Mitchell, Aşvan Kale, Keban Rescue Excavations, Eastern Anatolia (Oxford 1980) fig. 29.220, 223; D. Oates and J. Oates, Iraq 20 (1958) 114-57, pl. 23.2; T.J. Wilkinson, Town and Country in Southeastern Anatolia I: Settlement and Land Use at Kurban Höyük and Other Sites in the Lower Karababa Basin (Chicago 1990) fig. B.14.20-21. B. Dr. no. 92.22, HN103, op. 3, loc. 1, lot 2, rim diam. $=19 \mathrm{~cm}$, "fish plate": cf. Tarsus fig. 120.34; Mitchell (supra) fig. 29.228. C. Dr. no. 93.465, op. 7, loc. 9, lot 26, rim diam. $=17 \mathrm{~cm}$, "fish plate": cf. P.M. Kenrick, in J. Matthers ed., The River Qoueiq, Northern Syria, and Its Catchment (Oxford 1981) 439-58, type 18. D. Dr. no. 93.100, HN1268, op. 4, loc. 12, lot 22, hemispherical bowl: cf. Hama fig. 4.48; Tarsus figs. 121.51, 178.3, 5, and 180.79; Kenrick (supra) type 8; Mitchell (supra) fig. 27.165; Oates and Oates (supra) pl. 23.14-16; Wilkinson (supra) fig. B.14.1-3, 46. E. Dr. no. 92.1, HN103, op. 3, loc. 1, lot 2, rim diam. $=20 \mathrm{~cm}$, hemispherical bowl: cf. Hama figs. 4.47, 49 and 6.57; D. French, J. Moore, and H. Russell, AnatSt 32 (1982) 161-87 fig. 13.3; Tarsus figs. 122.71, 178.5, and 180.52, 67, 68, 80; Kenrick (supra) type 8; Mitchell (supra) figs. 23.14, 27.148; Oates and Oates (supra) pl. 23.29. F. Dr. no. 92.19, HN103, op. 3, loc. 1, lot 2, rim diam. $=14$ cm, "krater": cf. Tarsus fig. 128.141; Mitchell (supra) fig. 38.475. G. Dr. no. 92.18, HN103, op. 3, loc. 1, lot 2, rim diam. = 12 cm, "krater": cf. Mitchell (supra) fig. 21.3. H. Dr. no. 92.21, HN103, op. 3, loc. 1, lot 2, rim diam. $=4 \mathrm{~cm}$, bottle, similar to Tarsus fig. 135.235-48. I. Dr. no. 92.14, HN103, op. 3, loc. 1, lot 2, rim diam. $=16$ cm, "skyphos": cf. Tarsus figs. 123.84, 86 and 181.82-86; Kenrick (supra) type 59. J. Dr. no. 93.464, HN1277, op. 4, loc. 13, lot 24, bowl: cf. Hama fig. 10.107-109; Mitchell (supra) fig. 29.204, 211. K. Dr. no. 93.466, op. 7, loc. 12, lot 13, jar shoulder with stamp-impressed decoration. L. Dr. no. 93.461 , op. 4, loc. 12, lot 21/22, base diam. $=13 \mathrm{~cm}$, bowl base: cf. Hama fig. 8.70; Tarsus figs. 119.1, 2, 13 and 122.66. M. Dr. no. 93.467, op. 7, loc. 9, lot 26, body sherd with incised decoration. N. Dr. no. 93.471 , HN3047, op. 7, loc. 11, lot 14, Attic red-figure body sherd. 

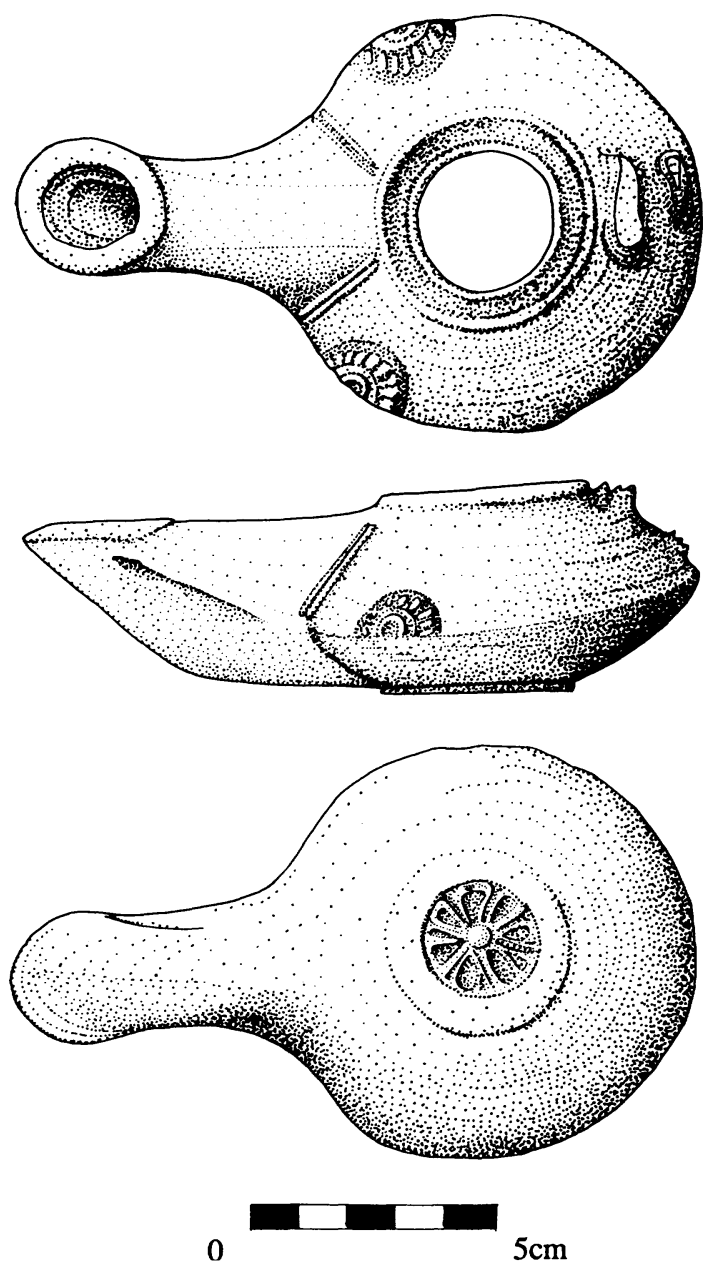

Fig. 17. Hellenistic oil lamp HN3175: cf. Tarsus Tarsus Group VI ( = Corinth type 19)

similar to that found at Deve Hüyük, including com parable jewelry, mirrors, incised bone objects, twee. zers, frit scarabs with incised figures on the bases, and alabaster vessels.

Two small excavations, operations 8 and 9, were located in areas of high resistivity or magnetic anomaly in the central portion of the Hacinebi mound in order to test the accuracy of the geophysical survey. Operation 8 was a $2 \times 10 \mathrm{~m}$ trench in. tended to investigate a large circular anomaly on the magnetic survey map and a possible northeastsouthwest wall on the resistivity map. It was hypothesized that the circular anomaly might have been caused by a kiln or kilns. In fact, the excavation did uncover a series of bread ovens in this location as part of a possible domestic quarter. Rather than a wall, however, there were instead a number of Hellenistic pits. The depth of deposit in this operation, over $2.5 \mathrm{~m}$, with a number of distinct habitation levels, implies that the site was occupied over a substantial length of time within the Hellenistic period. Further study of the ceramic remains from this trench should allow a finer definition of the time range involved. Operation 9 was located where the resistivity survey indicated another possible structure with large walls; upon excavation, however, this area also proved to hold a deep sequence of Hellenistic pits.

\section{FINDS}

A nonrandom sample of sherds from the Hel. lenistic layers of operations 3,4 , and 7 was selected for a brief preliminary study. Since the pits cut into the monumental architecture in these trenches produced the most pottery, the assemblage described here falls largely within the range of the second to third centuries B.C., with parallels coming from Tarsus, Aşvan Kale, and Hama. The most distinctive shapes include shallow "fish plates" with flaring rims (fig. 16: A-C) and hemispherical bowls with inturn. ing sides (fig. 16: D-E). Other shapes represented include a variety of jar rims (fig. 16: $\mathrm{F}-\mathrm{H}$ ), doublehandled skyphoi (fig. 16: I), and a deep flared-rim bowl (fig. 16: J). The ware was generally tempered with a mixture of fine organic material and sand, with walls from $3 \mathrm{~mm}$ to $1.5 \mathrm{~cm}$ thick. Surface detailing is rare; a few sherds are decorated with impressed (fig. 16: K-L) or incised (fig. 16: M) decoration. One jar rim has a band of paint or slip on the exterior rim (fig. 16: G), and one fish plate has red slip covering the interior, which had dripped down the sides of the exterior. A single small sherd of Attic red-figure showing a human hand and arm (fig. 16: N) is the only identifiable import thus far. Other objects from Hellenistic levels of all trenches include a large number of unbaked clay spindle whorls and several fragments of baked clay horse-and-rider figurines. A moldmade oil lamp (fig. 17) from operation 9 can be dated to the mid- to late second century B.C. by parallels from Tarsus and Corinth.

FACULTY OF ORIENTAL STUDIES UNIVERSITY OF CAMBRIDGE

SIDGWICK AVENUE

CAMBRIDGE CB3 9DA

ENGLAND 


\section{PRELIMINARY REPORT ON THE GLYPTIC ART: HACINEBI, 1993}

\section{Holly Pittman}

The 1993 excavation season at Hacınebi Tepe produced a significant corpus of glyptic art that provides evidence for two distinct systems of administrative praxis at the site during the second half of the fourth millennium B.C. One is closely related to administration systems used at sites in southern Mesopotamia, most prominently at Uruk and Susa ${ }^{50}$ The other is essentially identical to the indigenous southeastern Anatolian administration, best known from the Late Ubaid site of Değirmentepe ${ }^{51}$ and the Late Uruk site of Arslantepe. ${ }^{52}$ The two types of administrative evidence were found in separate archaeological contexts at Hacınebi. This report summarizes the characteristics of the two systems, focusing on the iconographic and stylistic character of the glyptic art and the administrative function of the impressed sealings. All exemplars are known through impressions on clay administrative artifacts.

\section{ADMINISTRATIVE MATERIAL RELATED TO} THE LATE URUK CULTURAL HORIZON

During the 1993 season, one example related to the southern Mesopotamian administrative system was retrieved as a surface find in operation 6 , in the northern area of the site, where most of the Uruk material culture has been recovered to date. It is a spherical clay ball, or bulla, formed around 12 clay tokens and impressed on its surface with two differ. ent cylinder seals (figs. 18a-b). Bullae are a key component in an accounting system thought to be the immediate precursor of the world's earliest writing, which developed in southern Mesopotamia toward the end of the Uruk period, ca. 3200 B.C. The earliest examples of written script have been retrieved

\footnotetext{
${ }^{50}$ For a concise and comprehensive review of the evidence for the origins of writing, see H. Nissen, P. Damerow, and R. Englund, Archaic Bookkeeping: Early Writing and Tech. niques of Economic Administration in the Ancient Near East (Chicago 1993).

${ }^{51}$ U. Esin, "Some Small Finds from the Chalcolithic Occupation at Değirmentepe (Malatya) in Eastern Turkey," in Liverani et al. (supra n. 7) 253-63; U. Esin and S. Harmankaya, "Değirmentepe (Malatya) Kurtarma Kazısı 1986," IX. Kazı Sonuçları Toplantısı (Ankara 1987) 79-125.

${ }^{52} \mathrm{M}$. Frangipane and A. Palmieri, "Perspectives on Protourbanization in Eastern Anatolia: Arslantepe (Malatya). An Interim Report on the 1975-1983 Campaigns," Origini 12 (1988) 287-454; Frangipane and Palmieri, "Aspects of Centralization in the Late Uruk Period in the Mesopotamian Periphery," Origini 14 (1988-1989) 539-60; Frangipane, "New Groups of Clay Sealings from the 4th
}

from level IV of the sounding in the Eanna precinct at the site of Uruk. These hollow clay spheres were frequently filled with unbaked clay tokens of differ. ent shapes and sizes; one theory is that each type of token represented a designated quantity of a par. ticular commodity such as sheep, goats, barley, or slaves. ${ }^{53}$ Anywhere from one to three cylinder seals were frequently impressed over the moist surface of the bulla, although unimpressed examples are also known. On some bullae, the surface was subsequently impressed with shapes that reproduced the enclosed tokens. Such clay balls have been found together with numerical tablets, ovoid tags, and clay seal impres. sions at a number of sites, including Uruk, Susa, Choga Mish, and Habuba Kabira-South. The most closely controlled sequence is that from the Acropole sounding at Susa, where the clay balls were found in level 18 and in much-diminished numbers in level 17 , dated on the basis of ceramic parallels to the beginning of the Late Uruk horizon. ${ }^{54}$ The clay ball from Hacınebi is particularly close to those found at Susa and Choga Mish. ${ }^{55}$

The Hacınebi bulla is $7.8 \mathrm{~cm}$ in diameter and is made from well-levigated clay. Although broken when found, it still contained 12 tokens of unbaked clay that range in size from 1 to $2.5 \mathrm{~cm}$. Four different shapes are represented - six small spheres, four large spheres, one disk, and one lentoid. The disk was apparently incised with a single line. The distorted shapes of several tokens indicate that they were still moist when encased in the bulla.

While there is no trace of token-shaped impressions on its surface, the clay ball/bulla was clearly impressed with two different cylinder seals. The first seal was rolled around the circumference of the ball;

Millennium Levels of Arslantepe-Malatya," in M. Mellink, E. Porada, and T. Özgüç eds., Aspects of Art and Iconography: Anatolia and Its Neighbors. Studies in Honor of Nimet Özü̈ (Ankara 1993) 191-200.

${ }^{53}$ D. Schmandt-Besserat, Before Writing: From Counting to Cuneiform (Austin 1992), although other scholars have challenged this interpretation.

${ }^{54} \mathrm{~A}$. Le Brun and F. Vallat, "L'origine de l'écriture à Suse," Cahiers de la Délégation archéologique française en Iran 8 (1978) 11-60.

${ }^{55}$ See, e.g., P. Amiet, Glyptique susienne: Des origines à lépoque des Perses achéménides (Mémoire de la Délégation archéo logique française en Iran 43, Paris 1972) nos. 488, 539, and 689; P. Delougaz and H. Kantor, "New Evidence for the Pre. historic and Protoliterate Cultural Development of Khuzis. tan," in The Memorial Volume of the Vth International Congress of Iranian Art and Archaeology 1 (Tehran 1972) 14-33. 


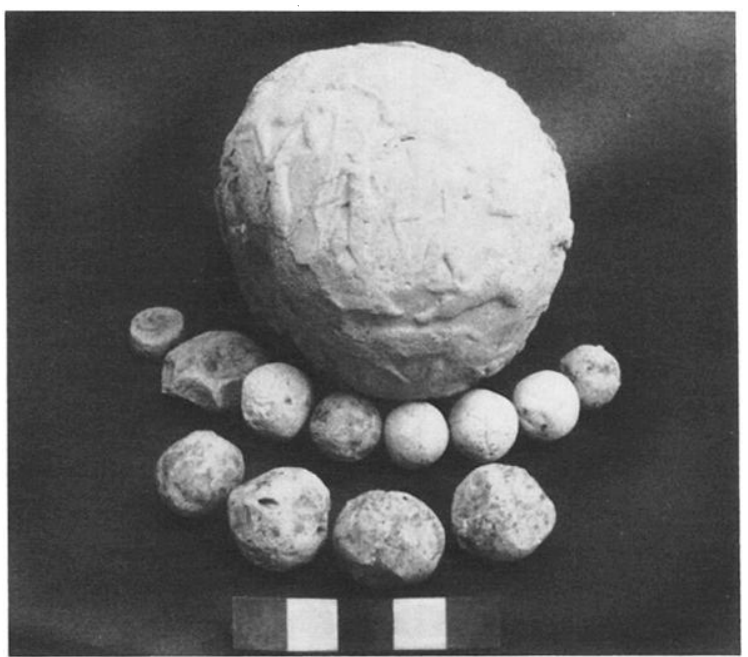

Fig. 18a. Uruk cylinder seal impressed hollow clay ball/bulla HN1100

the second was impressed in the remaining surface at both the ends. ${ }^{56}$ Both impressions were made by cylinder seals that are closely paralleled at Susa, and less closely at Uruk, both stylistically and iconographically (fig. 19). The first cylinder seal was engraved with an animal file on which a bovid is shown closely following a feline (identified by its long, curled tail) turning its head back. It is likely that there were at least one if not two more animals in the complete design. ${ }^{57}$ The second seal was impressed on the clay ball on the free surface above and below the animal file. It can be completely restored. On it was carved a two-part scene showing a nude male carrying a staff followed by two males wearing penis sheaths and carrying bows. This file of humans walks toward a structure shown in profile having a rounded top. In front of the structure squat two so-called "pigtailedladies" with elaborately coiffed long hair. The lower female faces a small Inanna symbol, behind which is a thick ring. Above her, an identical female squats and holds a long form with a swelling bottom, perhaps an animal tail. 58

The style of carving, iconography, composition, and the context of use all suggest that the seals impressed on the Hacinebi clay ball/bulla date to the equivalent of Susa Acropole sounding levels 17b-18. The ball from Hacinebi has been sampled for neu-

\footnotetext{
${ }^{56}$ This administrative practice is identical to that observed by Helene Kantor on the clay balls from Choga Mish (Abbas Alizadeh, personal communication).

${ }^{57}$ From Susa, close parallels are Amiet (supra n. 55) no. 544; Godin Tepe, P. Amiet, Glyptique mésopotamienne archaique $^{2}$ (Paris 1980) no. 1677.
}

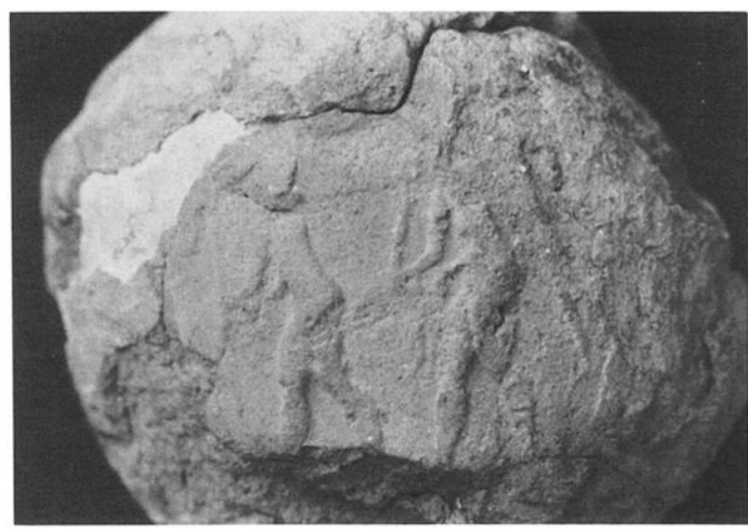

Fig. 18b. Detail of cylinder seal impression on HN1100

tron activation analysis by M. James Blackman (Smithsonian Institution); the chemical composition will be compared to clay balls from other sites, including Susa.

\section{ADMINISTRATIVE MATERIAL OF} THE INDIGENOUS ANATOLIAN SYSTEM

The second main class of administrative material found at Hacinebi Tepe during the 1993 season was clay sealings used to close or mark a variety of containers. These were often impressed with a variety of stamp seals. Thirty-four distinct seals are repre.
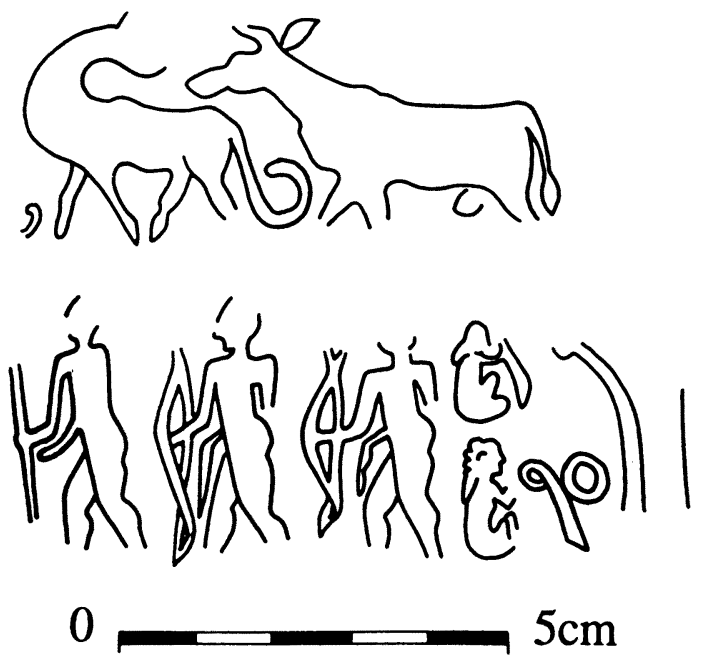

Fig. 19. Cylinder seal motifs from Uruk bulla HN1100

\footnotetext{
${ }^{58}$ The closest parallels for both scenes are found among the seal impressions on anepigraphic administrative documents from Susa. For the file of archers, cf. Amiet (supra n. 55) nos. 684,688 , and 689 . Representations of squatting females adjacent to structures occur frequently; see Amiet (supra n. 55) nos. 667, 669.
} 
A

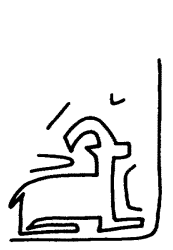

B

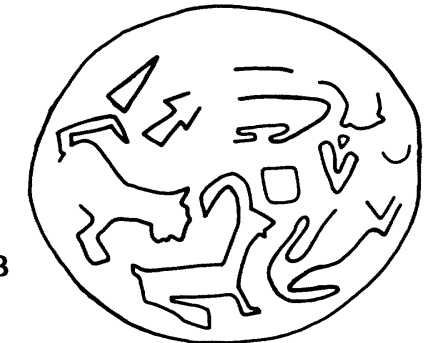

C

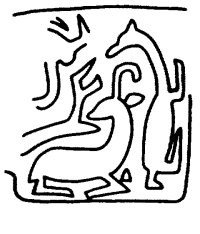

D

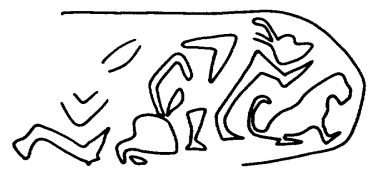

E

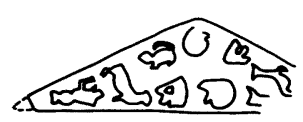

E

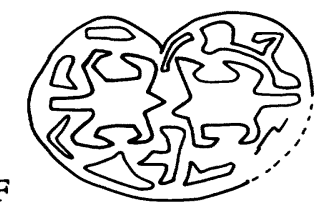

$5 \mathrm{~cm}$

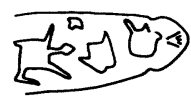

G

Fig. 20. Main motifs on Local Late Chalcolithic stamp seal impressions (op. 6, pit 84): A. Caprid HN3912;

B. Lion and caprid HN3398; C. Lion and caprid HN3399; D. Protomes HN3810; E. Protomes HN3867;

F. Turtle or tortoise? HN3894; G. Turtle or tortoise? HN3802

sented through impressions on over 100 clay sealings. About a dozen of the seals can be reconstructed; the rest are very fragmentary. All were retrieved from a single context, pit 84 in operation 6 in the northeastern part of the mound. ${ }^{59}$ While cylinder seals are the glyptic type preferred in the southern Mesopotamian administrative systems during the protoliterate horizon, the widespread use of stamp seals at Hacınebi Tepe is consistent with the system of administration practiced at Local Late Chalcolithic sites in the Taurus piedmont zone and the northern Syrian and Mesopotamian steppe at sites such as Arslantepe, Gawra, and Brak. Although local cylinder seals cut in emulation of Late Uruk types have been found at Arslantepe ${ }^{60}$ no examples of a local cylinder seal tradition were found at Hacinebi in 1992-1993.

\section{Shapes}

Shape is a distinctive feature that serves to differ. entiate stamp seals. A wide variety of shapes are found among the impressions of stamp seals from pit 84, including rectangles, ellipses, squares, large and small circles, kidney, and cigar shapes. Because only impressions and no actual seals were found, we lack crucial information concerning the seals' third dimension. Thus we do not know if the square and rectangular bezels were gable-shaped or flat; nor do we know if the stamp seals with the circular bezels are hemispherical, round, lentoid, or pyramidal. ${ }^{61}$

\footnotetext{
${ }^{59}$ One fragmentary stamp seal impression on a jar sealing was found in a Late Chalcolithic phase B deposit on the south side of the mound (HN477, op. 2, locus 14). An additional sealing impressed with a ring bezel carved with a feline was found in a Hellenistic deposit (HN3763, op.
}

\section{Iconography and Composition}

The stamp seals depict a limited range of subjects. Caprids are by far the most common motif, typically represented facing right, either walking or recum. bent. The animal is consistently shown having a single horn in profile, and usually has a short, pointed beard (fig. 20: A-C). In one instance, the animal has its head turned back. Caprids are shown together with other caprids, felines, and, less frequently, birds. The caprid is known both as a full-bodied creature and also as a protome (fig. 20:D-E), certainly a feature borrowed from Late Uruk imagery.

The second most common subject is the feline. This creature does occasionally occur alone but more frequently it is combined with caprids (fig. 20: B-C). Another theme documented among the 1993 finds is a tortoise or turtle (?) (fig. 20: F-G). Two examples were found, one engraved on a kidney-shaped seal, the other on a small seal with a long narrow bezel. Remarkable for their absence are representations of bovids and snakes.

The composition of the scenes is determined to a large degree by the shape of the stamp seal. The animals engraved on the square or rectangular seals are usually arranged in a line; but they can also be organized with reference to the seals' edge. This is the most common compositional formula used on circularloval stamps from Hacinebi Tepe found in 1993 (fig. 20: B). The other compositional formula

\footnotetext{
9, locus 32).

${ }^{60}$ Frangipane (supra n. 52) 195, nos. 1-2.

${ }^{61}$ See A. von Wickede, Prähistorische Stempelglyptik in Vorderasien (Munich 1990) for a complete review of prehistoric stamp seals in the Near East.
} 

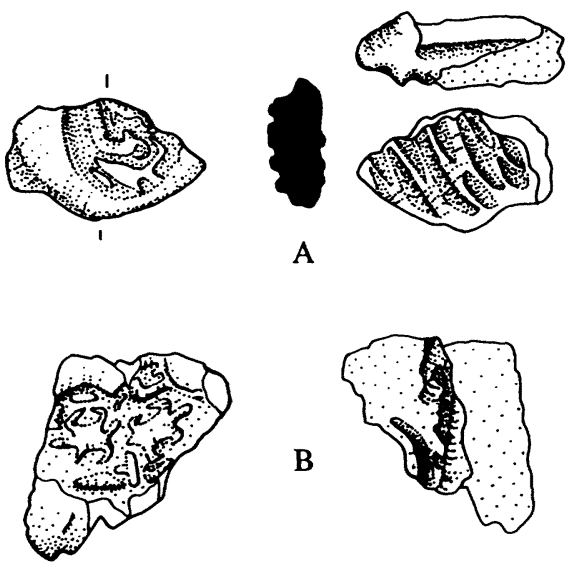

B
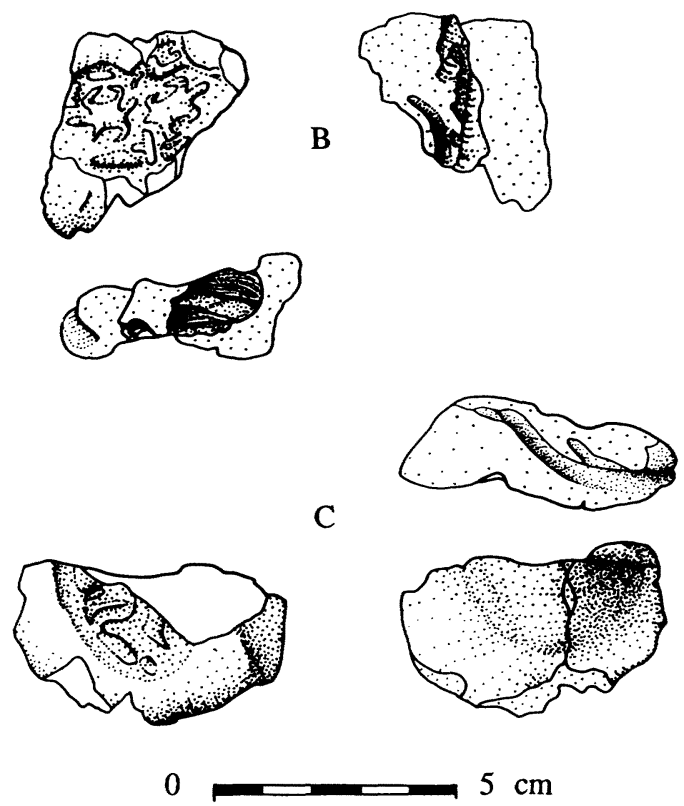

Fig. 21. Local Late Chalcolithic stamp sealing functions: obverse with seal impression (left); reverse (right) (op. 6, pit 84): A. Woven wicker basket impression HN3885; B. Sack sealed with peg HN3894; C. Leather covering on jar rim HN3888

worth noting is the rampant opposition of feline and caprid. While this composition is common on cylinder seals of the period, I can find no examples of it among excavated stamp seals or sealings.

\section{Function}

The reverse sides of the clay sealings often bear the impressions of the objects to which they were affixed, thereby giving some indication of the activities or functions that were being administered in the Late Chalcolithic settlement. The clay sealings impressed with stamp seals were most frequently used as locks for mobile storage containers. The most common sealing device is a clay disk or wedge applied to a sack container that was closed with a peg (fig. 21: B). Similarly shaped disks or wedges were pressed against containers made of or covered with matting, leather (fig. 21: C), or more rarely fabric. In a number of cases, wicker baskets were secured with clay sealings (fig. 21: A). The range of functions among the Hacınebi stamp sealings is virtually identical to that found at the earlier Ubaid site of Değirmentepe in the Malatya region to the north. Arslantepe has a wider range of sealing types that includes numerous door and jar sealings.

No examples of anepigraphic documents, such as the tags known from Gawra, were found at Hacinebi in 1992-1993, unless the many examples of small seal-impressed disks can be considered as such. In addition, none of the Hacinebi stamp sealings found to date can be confidently identified as door sealings.

\section{CONCLUSIONS}

The impressed clay ball found at Hacinebi is incontrovertible evidence for direct contact with Late Uruk centers in southern Mesopotamia, or indirect contact with them through the "colonies" along the Euphrates or the Transtigridian piedmont corridor. If finds from other sites are any indicator, it is likely that the entire administrative tool kit of the Late Uruk colonies will be found at Hacınebi, including numerical tablets, ovoid tabs, and clay balls. The existence of both indigenous and foreign administrative systems at Hacınebi is so far unique. At the Anatolian site of Arslantepe, for example, local administrative materials, including glyptic, have been found that closely emulate the southern examples. On the other hand, at Habuba Kabira-South and Jebel Aruda, sites that were certainly occupied by people from the southern Mesopotamian centers, no evidence has yet been found for the use of the indigenous Anatolian stamp seals. The coexistence of the two sealing practices at Hacinebi thus provides a rare opportunity to study the interaction between Mesopotamian and Anatolian administrative systems and their related economic activities.

DEPARTMENT OF ART HISTORY
34OO WALNUT STREET
UNIVERSITY OF PENNSYLVANIA
PHILADELPHIA, PENNSYLVANIA $19104 \cdot 6208$
HPITTMAN@MAIL.SAS.UPENN.EDU

HPITTMAN@MAIL.SAS.UPENN.EDU

\section{HACINEBI URUK POTTERY: PRELIMINARY REPORT}

\section{Susan Pollock and Cheryl Coursey}

The ceramic analysis undertaken in the summer of 1993 had several goals. The first and most basic was to devise a typology for the Hacınebi pottery assemblage. Preliminary observations had indicated 
that there were close parallels with Late Chalcolithic pottery from the region (from sites such as Kurban Höyük, Karatut Mevkii, Hassek Höyük, and Arslantepe) as well as with southern Mesopotamian Uruk pottery. The purpose of developing a new typology was to refine the chronology of the Late Chalcolithic pottery assemblage. Our second goal was to analyze spatial distributions of local and Uruk-related pottery forms within the site. Suggestions that there may be a segregation of Uruk-related and local styles of material culture within the community required closer examination, in light of a finer chronology and analysis of the contexts in which the materials were found. The final objective was a comparative functional analysis of local and Uruk-related pottery. This is closely tied to the second objective, since it involves analysis of which functional categories of vessels are found in particular contexts.

A preliminary report on the Late Chalcolithic pottery has been published elsewhere. Here we concentrate on the Uruk-related material, since the presence of such material well outside the alluvial lowlands has prompted much scholarly debate. ${ }^{62}$ Only selected portions of the pottery from the 1992-1993 seasons were examined. They included material from operations 1,2 , and 5 that came from what we judged to be primary or secondary contexts. Approximately 10,000 diagnostic sherds were recorded individually.

We begin by considering the range of Uruk-related pottery that is attested at Hacınebi. It is important to note in this regard that comparisons are based on morphological similarities and not on fabrics or wares. In northern Mesopotamia, the use of mineral inclusions in pottery (apart from beveled-rim bowls and some large, coarsely made forms such as trays) is frequently taken as an indicator that the pottery is Uruk. However, our observations of Uruk pottery from the alluvial lowland site of the Uruk Mound of Abu Salabikh indicate that sherds from nearly all vessel types frequently contain some vegetal material. At Hacinebi most of the identified Urukrelated types, with the notable exception of beveledrim bowls and trays, are made using fabrics that con-

\footnotetext{
62 We use the term "Uruk" to refer to styles of material culture that characterize southern Mesopotamian sites in the fourth millennium. By "Uruk-related" we mean that particular pottery forms are similar but not necessarily identical to known Uruk pottery.

For a report on the Late Chalcolithic pottery, see S. Pollock and C. Coursey, "Ceramics from Hacınebi Tepe: Chronology and Connections," Anatolica 21 (1995) 101-41. For scholarly debate, see, e.g., Algaze 1989; Algaze 1993; Johnson (supra n. 13); Stein and Misır.
}

tain mineral inclusions, but a number of examples have vegetal inclusions. Conversely, some examples of local forms contain mineral inclusions. Thus, inclusions alone are not sufficient to identify a sherd as Uruk.

Specific parallels with Uruk material from other sites are presented in table 3 . We have intentionally been cautious in drawing parallels, preferring to err on the side of excluding some forms that may be Uruk-related rather than the reverse. In a number of cases, the few examples of a type from Hacinebi, along with the small portion of the vessel preserved and a relatively simple rim and neck shape, com. bine to make it difficult to argue with any certainty for a particular form corresponding to an Uruk type.

Bowls. Two types of bowls, beveled-rim bowls (BRB) and fine conical bowls with or without lip spouts (fig. 22: A-F), find close parallels in Uruk as. semblages. BRBs occur in great quantities at Hacınebi (nearly 4,000 rims and full profiles were recorded), and fine conical bowls, although not nearly as numerous, are nonetheless relatively common (over 150 rim sherds recorded). Another bowl type, coarse conical bowls (fig. 22: $\mathrm{G}-\mathrm{H}$ ), is clearly related in manufacture (wheel-thrown, often "off the hump") to the southern Mesopotamian Uruk and Jemdet Nasr mass-produced conical bowl tradition. The Hacınebi coarse conical bowls, however, are morpho logically more similar to those that Frangipane identifies at Arslantepe as an outgrowth of a local Anatolian tradition of mass-produced bowls ${ }^{63}$ rather than the taller variety common in southern Mesopotamia at the end of the fourth millennium. ${ }^{64}$

Jars. A variety of round-rim jars occur at Hacınebi that exhibit close parallels with Uruk forms. These include short, squat vessels with plain round rims and short necks, often with a handle and parallel grooved lines on the shoulder (fig. 23: A-D); those with short necks and thickened rims, usually with a slight depression on the interior of the rim (fig. 23: E-G); others with low necks and flared rims, commonly with parallel grooved lines on the shoulder, which appear to come in several different sizes (fig. 23: I-J); and vessels with high necks, flared or everted

\footnotetext{
${ }^{63} \mathrm{M}$. Frangipane, "Produzione di vasellame in serie e distribuzione di razioni alimentari nelle società protour. bane del periodo tardo Uruk-Jemdet Nasr," in G. Susini ed., Il pane del re. Accumulo e distribuzione dei cereali nell'Oriente antico. Studi di storia antica (Bologna 1989) 49-63, fig. 1b; Frangipane (supra n. 26).

${ }^{64}$ See, e.g., Pollock (supra n. 34) figs. 3-4; H. Nissen, "Grabung in den Quadraten K/L XII in Uruk-Warka," BaM 5 (1970) 101-91, table 104 nos. 2-6, 8.
} 
Table 3. Selected Parallels between Pottery from Hacınebi and Other Sites with Uruk Material

\begin{tabular}{|c|c|c|}
\hline Hacinebi Pottery & Parallels from Other Sites & Dating \\
\hline $\mathrm{BRB}$ & All Uruk sites & From late EU on \\
\hline Fine conical bowls & $\begin{array}{l}\text { Sfbd: } 299003,08422,02734 \\
\text { Warka: no. } 153 \\
\text { AbS(1): fig. 6e, f, j; (2): fig. } 4 \text { b, c } \\
\text { Brak: fig. } 51: 33-35\end{array}$ & $\begin{array}{l}\text { MU } \\
\text { MU/LU (L.VII) } \\
\text { MU-JN } \\
\text { MU }\end{array}$ \\
\hline $\begin{array}{l}\text { Plain round rim jars with } \\
\text { short necks, often with } \\
1 \text { handle }\end{array}$ & $\begin{array}{l}\text { HK: tab. 5: } 57-58 \\
\text { Sfbd: object } 133 ; 00806,04527 \\
\text { Warka: no. } 183 \\
\text { AbS(1): fig. } 9 \mathrm{a} ;(2) \text { : fig. } 5 \mathrm{~d} \text {; } \\
\quad \text { (3): U4266: } 229 \text {, U4149: } 80 \\
\text { Brak: cf. fig. } 50: 8\end{array}$ & $\begin{array}{l}\text { LU* } \\
\text { MU } \\
\text { MU (L.VIII) } \\
\text { MU-JN } \\
\text { LU }\end{array}$ \\
\hline $\begin{array}{l}\text { Flared round rim jars } \\
\text { with low-medium necks }\end{array}$ & $\begin{array}{l}\text { HK: tab. 13: } 81-82 \\
\text { Sfbd: 0138, 01506, 02711, } 24605 \\
\text { AbS(3): U2001: 6, U2002: } 1 \\
\text { U2046: } 71, \text { U1052: } 4 \\
\text { U4269: } 152\end{array}$ & $\begin{array}{l}\mathrm{LU} \\
\mathrm{MU} \\
\mathrm{EU}-\mathrm{JN}\end{array}$ \\
\hline $\begin{array}{l}\text { High-necked jars with } \\
\text { thin, flared round rims }\end{array}$ & $\begin{array}{l}\text { HK: tab. 15: 87-88, 16: 94, 96-98 } \\
\text { AbS(3): U1040: 19, U4149: } 85 \\
\text { Brak: fig. 49: 4; 50: } 6,12\end{array}$ & $\begin{array}{l}\text { LU } \\
\text { MU-JN } \\
\text { LU-JN }\end{array}$ \\
\hline $\begin{array}{l}\text { Jars with short necks and } \\
\text { thickened round rims } \\
\text { that have slight interior } \\
\text { grooves }\end{array}$ & $\begin{array}{l}\text { Warka: nos. } 284,285,290 \\
\text { Susa: Acr III, layer 7: } 1114.08 \\
\text { AbS(3): U2000: 4, U2001: } 7 \text {, } \\
\text { U1059: } 8, \text { U4276: } 219\end{array}$ & $\begin{array}{l}\text { EU/MU (L.XIII/XII) } \\
\text { EU } \\
\text { MU }\end{array}$ \\
\hline $\begin{array}{l}\text { Jars with extended ledge } \\
\text { rims, often thickened }\end{array}$ & $\begin{array}{l}\text { HK: tab. 12: } 75-76 \\
\text { Warka: nos. } 49,50 \\
\text { Sfbd: } 02002,06516 \\
\text { AbS(3): U1011: } 1652 \text {, U2008: } 2 \text {, } \\
\quad \text { U2048: } 73, \text { U4286: } 140\end{array}$ & $\begin{array}{l}\text { LU } \\
\text { MU/LU (L.VI) } \\
\text { MU } \\
\text { EU-JN }\end{array}$ \\
\hline $\begin{array}{l}\text { Jars with low expanded } \\
\text { band rims }\end{array}$ & $\begin{array}{l}\text { HK: tab. } 26: 71-75 \\
\text { Sfbd: object } 114 \\
\text { Warka: nos. } 1,168,292 \\
\text { AbS(3): U1037: } 9 \text {, U4149: } 101 \\
\text { Brak: cf. fig. } 50: 9\end{array}$ & $\begin{array}{l}\mathrm{LU} \\
\mathrm{MU} \\
\mathrm{EU}-\mathrm{LU}(\mathrm{L} . \mathrm{XIII} / \mathrm{XII}, \mathrm{VIII} / \mathrm{VI}, \mathrm{VI} / \mathrm{V}) \\
\mathrm{MU}-\mathrm{JN} \\
\mathrm{MU}\end{array}$ \\
\hline $\begin{array}{l}\text { Jars with heavy } \\
\text { expanded rims }\end{array}$ & $\begin{array}{l}\text { HK: tab. 5: } 60 \\
\text { AbS(3): U4149: } 96, \mathrm{U} 4232: 78 \text {, } \\
\quad \text { U4237: } 191\end{array}$ & $\begin{array}{l}\mathrm{LU} \\
\mathrm{MU}\end{array}$ \\
\hline $\begin{array}{l}\text { Trays with heavy } \\
\text { flattened rims }\end{array}$ & $\begin{array}{l}\text { HK: cf. tab. } 23: 11 \\
\text { Warka: no. } 99 \\
\text { AbS(2): fig. } 5 \mathrm{i} \\
\text { Brak: fig. } 54: 71\end{array}$ & $\begin{array}{l}\text { LU } \\
\text { LU (L.VI) } \\
\text { JN } \\
\text { JN }\end{array}$ \\
\hline $\begin{array}{l}\text { Trays with incurved } \\
\text { round rims }\end{array}$ & $\begin{array}{l}\operatorname{AbS}(2) \text { : fig. } 2 \mathrm{i} \\
\text { Brak: cf. fig. 54: } 72\end{array}$ & $\begin{array}{l}\mathrm{EU} \\
\mathrm{MU}\end{array}$ \\
\hline
\end{tabular}

$\mathrm{HK}=$ Habuba Kabira-South; Sfbd = Sharafabad; UM = Uruk Mound at Abu Salabikh; EU = Early Uruk; MU = Middle Uruk; LU = Late Uruk; and JN = Jemdet Nasr. Sources for the parallels cited are: Habuba Kabira = HK: Sürenhagen (supra n. 67); Warka: Sürenhagen; Susa: H. Wright, in NatGeogRes Reports 19 (1985) 725-34; Uruk Mound Abu Salabikh = AbS(1): Pollock (supra n. 34), (2): S. Pollock, in Iraq 52 (1990) 85-93, (3): unpublished; Brak: Oates and Oates (supra n. 42). Examples from Sharafabad are unpublished and are cited courtesy of Henry Wright.

* Although Habuba Kabira-South is conventionally dated as Late Uruk, Sürenhagen's arguments (31-33) for a slightly earlier (but still Late Uruk) date should be borne in mind.

rims, usually with relatively narrow necks, either high or sloping shoulders that are occasionally decorated with punctate or reserve-slip, and one example of which has a spout (fig. 23: H, K; fig. 24: A-B).

Jars with flat rims that can be paralleled in Uruk assemblages include examples with ledge rims that are often thickened and extended, probably from relatively large vessels (fig. 24: C-D, F); those with heavy expanded rims, also from large vessels (fig. 23: $\mathrm{E}, \mathrm{G})$; and vessels with low expanded band rims that 
A

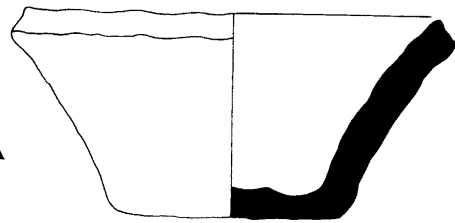

D.

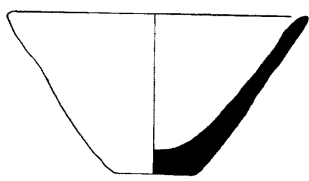

G

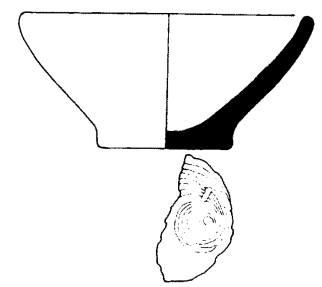

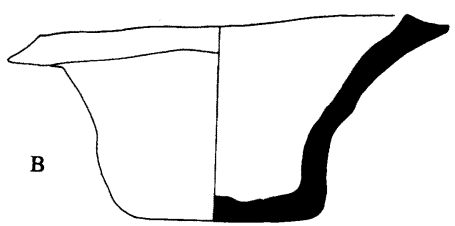

E
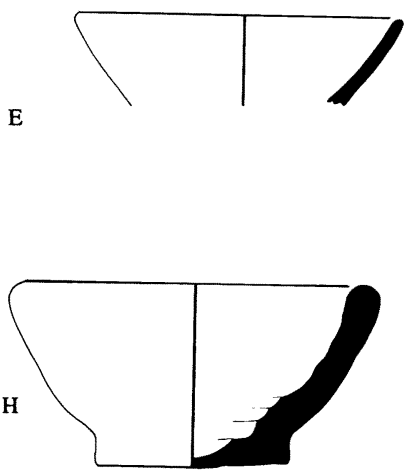
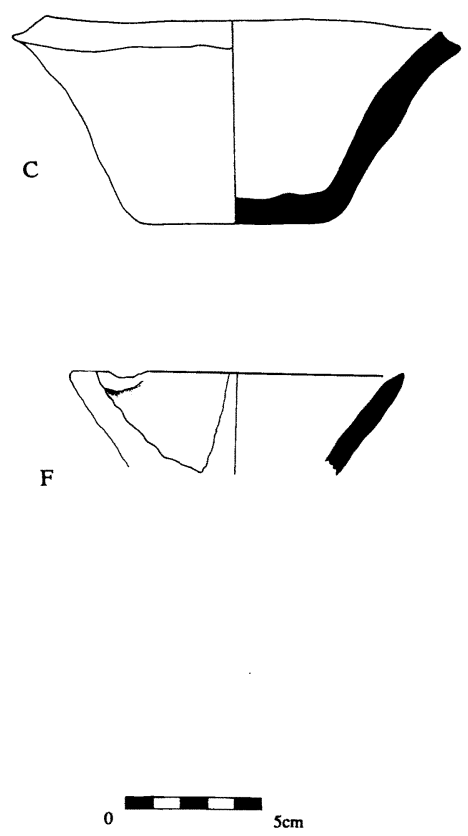

Fig. 22. Beveled-rim (BRB) and conical bowls $(\mathrm{R}=$ rim diam.; $\mathrm{B}=$ base diam.; $\mathrm{H}=$ height; Incl = inclusions in the paste; all measurements in $\mathrm{cm}$ ): $\mathrm{A}$. BRB, op. 1 , loc. 12 , lot 9 , $\mathrm{HN} 94, \mathrm{R}=16, \mathrm{~B}=7.9-8.0, \mathrm{H}=6.4-7.2$, vol $=450 \mathrm{ml}$, interior of base has swirl but no knuckle marks. B. BRB, op. 6 , loc. 49 , lot 59, HN2623, $\mathrm{R}=14.9, \mathrm{~B}=7.7, \mathrm{H}=7.8$. C. BRB, op. 6 , loc. 49 , lot 53 , $\mathrm{HN2617,} \mathrm{R}=15.4, \mathrm{~B}=8.2, \mathrm{H}=7.9$. D. Fine conical bowl, op. 1, loc. 12, lot 9, HN87:4, $\mathrm{R}=12, \mathrm{~B}=3.1, \mathrm{H}=5.8$, Incl = sandy; wheelthrown; trimmed around base. E. Fine conical bowl, op. 1, loc. 12, lot 10, HN207:92, R=12.5, Incl = sand; wheel-thrown. F. Fine conical bowl, op. 1, loc. 12, lot 10, HN207:146, R=13, Incl = sand; wheel-thrown; lip spout. G. Coarse conical bowl, op. 1, loc. 12, lot 10, HN207:15, R = 11, B = 4.6, Incl = sand; wheel-thrown; base shows marks of being cut off fast-moving wheel. H. Coarse conical bowl, op. 1 , loc. 12 , lot 9 , HN87:2517, $\mathrm{R}=13.5, \mathrm{~B}=7.5, \mathrm{H}=6.1$, Incl = sand and lime; wheel-thrown; base shows marks of being cut off fast-moving wheel.

seem to come in at least two distinct size classes, one of which is quite large (fig. 24: $\mathrm{H}-\mathrm{I}$ ). Although no bottles were found in the material that we recorded, at least one example was noted in the unrecorded units. Finally, a number of jar types with finer ledge rims may, upon further research and the recovery of more and better-preserved examples, turn out to have Uruk parallels.

Appendages. A small number of twist handles were recovered, none of them attached to rim sherds. Droop and conical spouts are attested, generally detached from vessels, but in two cases on round-rim jars. Several nose lugs have been found, in most cases associated with punctate decoration, and often with red wash.

Trays. A number of large trays exhibit similar rim shapes to those known from Uruk sites (fig. 24: J-L). Although parallels can be cited, the irregularity of the rims, even within a single vessel, and their rela- tively simple shapes caution against placing too much weight on morphological similarities alone.

\section{DISCUSSION}

In addition to specific parallels with pottery from other sites, table 3 presents associated dates for this material. These data indicate that the Hacinebi Urukrelated pottery includes types attributable to both Middle and Late Uruk. Although many of these types occur in both Middle and Late Uruk assemblages and hence cannot be used individually to argue for one date or the other, round-rim jars with interior rim depressions ("grooved round-rim jars": fig. 23: E, G) are diagnostically Early to (earlier) Middle Uruk and are not attested in Late Uruk assemblages. Some subtle features of other types, for example, the height of the bands of the low expanded band-rim jars and the occurrence of "knife-cut" bases on fine conical 


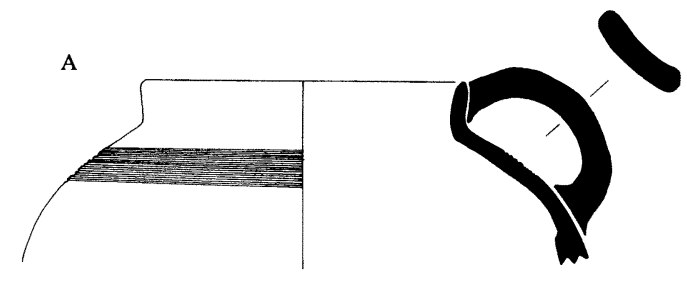

G

B

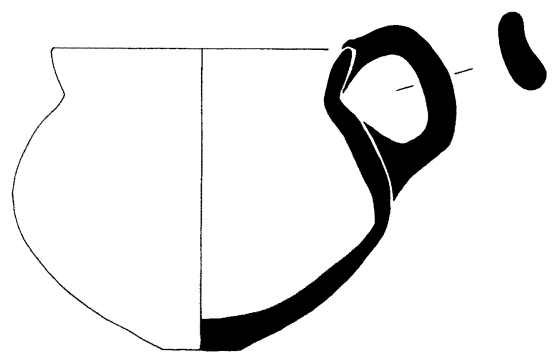

C

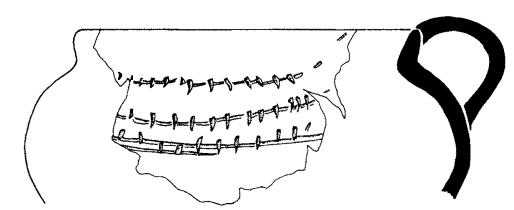

D

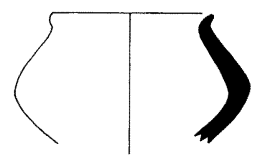

E
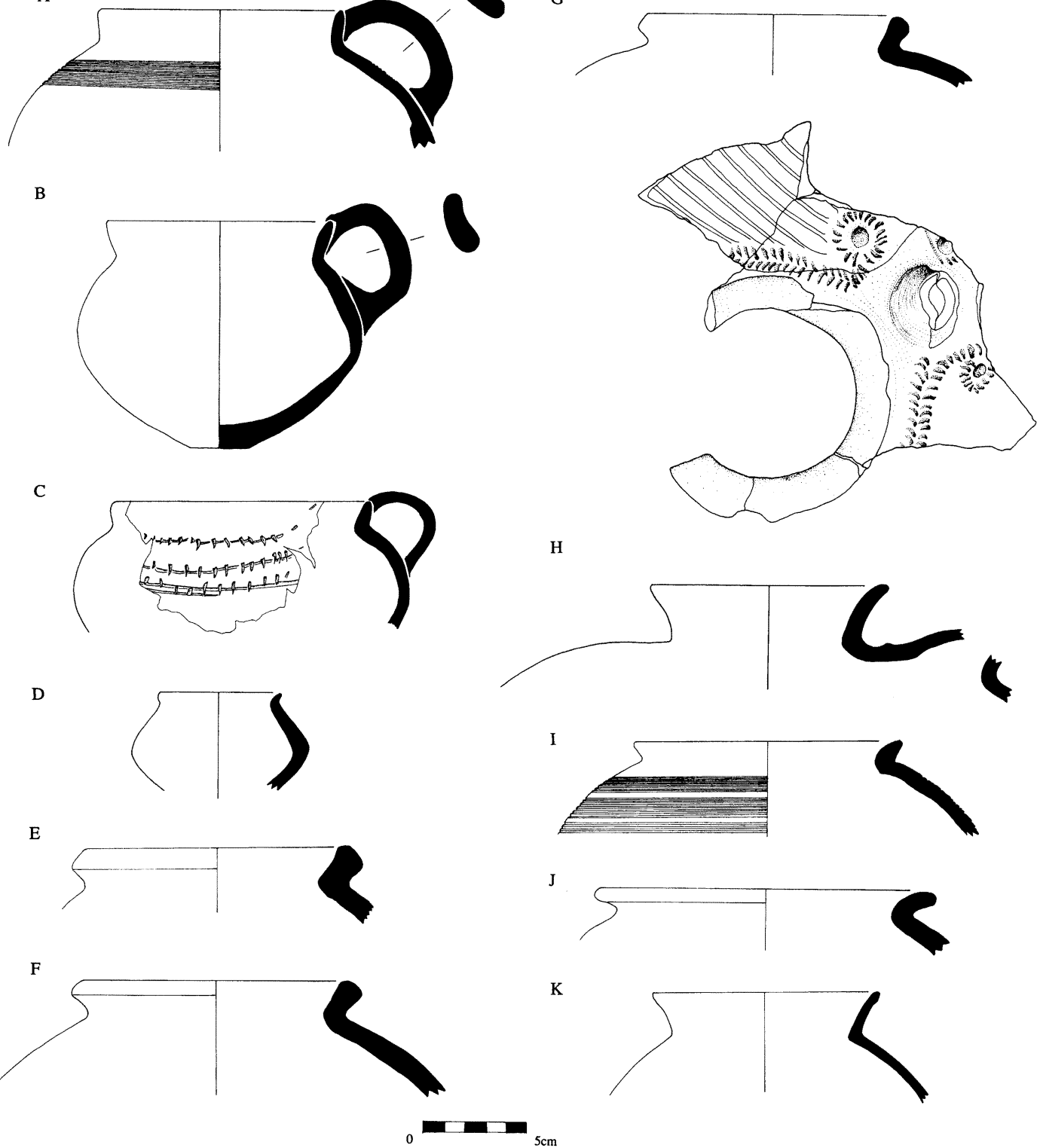

$\mathrm{H}$

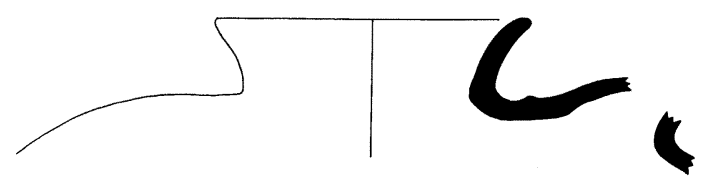

I

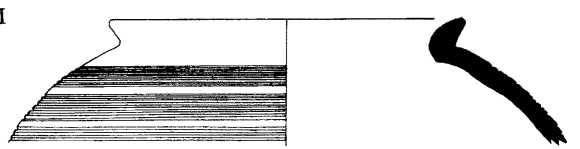

$\mathrm{J}$

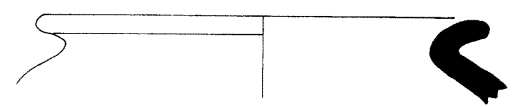

K

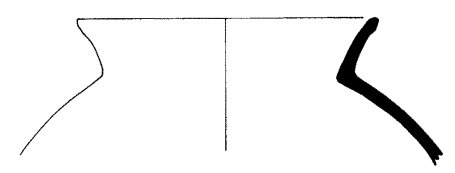

Fig. 23. Uruk-related round-rim jars (abbreviations as in fig. 22): A. Round-rim jar with short neck and strap handle, op. 1, loc. 12, lot 9, HN87:2651, $R=12$, Incl = sand; grooving on shoulder; handle has slight central depression. B. Round-rim jar with short neck and strap handle, op. 4, loc. 43, lot 109, HN2448:153, R=11, B = ca. 6, H = ca. 11.4, Incl = sand and lime; handle has central depression; red wash on the exterior of vessel and interior of rim; rim and exterior shoulder fire-blackened; exterior trimmed. C. Round-rim jar with short neck and strap handle, op. 1, loc. 31, lot 35, HN393:149, R= 7.7, Incl = sand; wheel-thrown; handle has central depression; incised lines with punctate through them; exterior shoulder fire-blackened. D. Round-rim jar with short neck, op. 1, loc. 31, lot 35, HN393:152, R =6, Incl = sand; wheel-thrown; trimmed below carination near base. E. Jar with thickened round rim with interior depression ("grooved round rim"), op. 4, loc. 43, lot 109, HN2448:401, $\mathbf{R}=14$, Incl = sandy. $\mathbf{F}$. Heavy round-rim jar, op. 1, loc. 31, lot 35, HN393:128, R=14, Incl = sand; handmade body, wheelfinished rim. G. Jar with thickened round rim with interior depression ("grooved round rim"), op. 1, loc. 12, lot 9, HN87:2629, $\mathbf{R}=13$, Incl = sand and lime. $\mathbf{H}$. Flared round-rim jar with high neck and spout, op. 1, loc. 12, lot 9, HN87:2663, $\mathbf{R}=11.5$, Incl = sand and lime; reserve-slip on shoulder, along with herringbone punctate and applied clay dots; handmade body, wheel-finished rim. I. Flared round-rim jar with low neck, op. 1, loc. 12, lot 9, HN87:2656, R = 13, Incl = sand; grooving on shoulder; wheel-thrown. J. Flared round-rim jar with low neck, op. 1, loc. 31, lot 35, HN393:133, R=16.5, Incl = sand and lime; exterior shoulder trimmed. K. Flared round-rim jar with high neck, op. 1, loc. 88, lot 100, HN1101:304, R = 11, Incl = sandy and lime; burnishing and possible wash on exterior. 
A

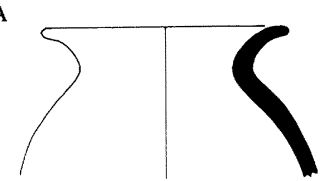

B

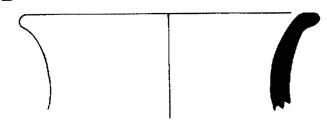

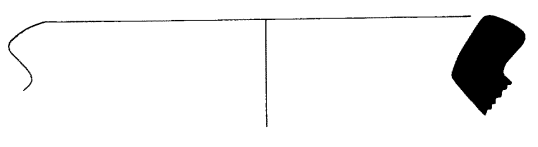

H

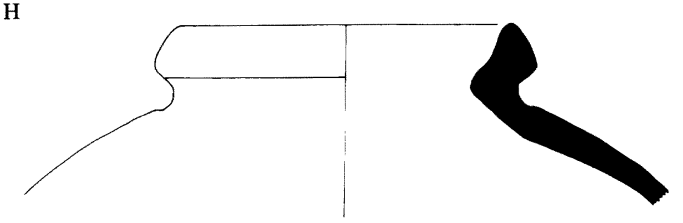

I

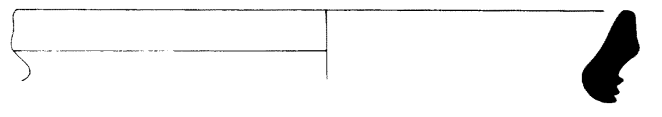

J

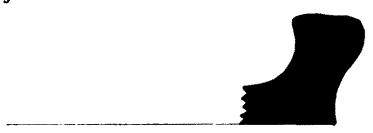

K

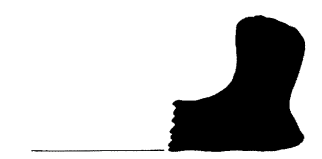

L

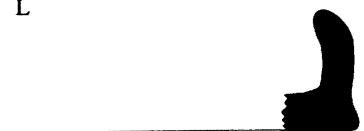

F
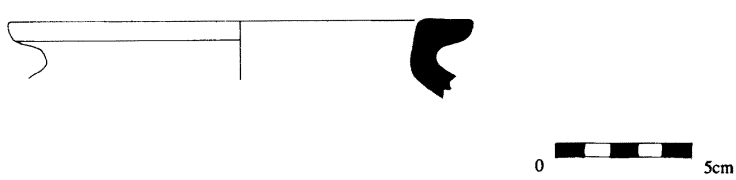

Fig. 24. Uruk-related jars and trays (abbreviations as in fig. 22): A. Flared round-rim jar with high neck, op. 1, loc. 94, lot 114, HN1155:71, R = 9, Incl = sandy and lime; possibly wheel-thrown. B. Flared round-rim jar with high neck, op. 1, loc. 31, lot 35, HN393:135, R = 11, Incl = sand; burnishing on exterior neck. C. Jar with extended ledge rim, op. 1, loc. 12, lot 10, HN207:174, R = 14.5, Incl = sand and lime; shoulder trimmed; possible evidence of join between rim/neck and shoulder. D. Jar with extended ledge rim, op. 1, loc. 37, lot 39, HN941:88, R = 18, Incl = sand and lime; interior and exterior shoulder trimmed. E. Jar with heavy expanded rim, op. 1, loc. 37, lot 39, HN941:84, R= 17, Incl = sand. F. Jar with extended ledge rim, op. 1, loc. 12, lot 10, HN207:57, R=17, Incl = sandy. G. Jar with heavy expanded rim, op. 1, loc. 12, lot 26, HN323:49, $\mathrm{R}=19$, Incl = sandy; wheel-thrown. H. Jar with low expanded band-rim, op. 4, loc. 24, lot $66, \mathrm{HN} 2108: 78, \mathrm{R}=14$, Incl = sandy; burnishing and red wash on exterior and rim. I. Jar with low expanded band-rim, op. 1, loc. 12, lot 9, HN87:2636, R=23, Incl = sand; wheel-finished or wheel-thrown rim. J. Tray with heavy flattened rim, op. 1, loc. 12, lot 26, HN323:2, R= ca. 40, $\mathrm{H}=4.0, \mathrm{Incl}=$ heavy grit and vegetal matter. $\mathrm{K}$. Tray with heavy flattened rim, op. 1, loc. 12, lot 9, HN87:15, $\mathrm{R}=$ indet., but very large, $H=4.4-5.0$, Incl = vegetal matter. $L$. Tray with incurved round rim, op. 1 , loc. 12 , lot $26, H N 323: 3, R=$ indet., $\mathrm{H}=4.3$, Incl = vegetal matter.

bowls also point to a Middle rather than a Late Uruk date. ${ }^{65}$

The Uruk-related pottery at Hacinebi includes a wide range of (Middle to Late) Uruk vessel forms.

\footnotetext{
${ }^{65} \mathrm{H}$. Wright, An Early Town on the Deh Luran Plain. Excavations at Tepe Farukhabad (Ann Arbor 1981) 95, 165.

${ }_{66}^{6}$ Adams and Nissen figs. 30: o, 44.6, and 54.1.
}

A number of forms, however, are either rare or un. attested. These include bottles, often with droop spouts; ${ }^{66}$ jars with relatively heavy neckless ledge rims $;{ }^{67}$ four-lugged jars with short necks, high promi-

${ }^{67}$ Adams and Nissen figs. 30: g and 56.9; D. Sürenhagen, "Untersuchungen zur Keramikproduktion innerhalb der spät-Urukzeitlichen Siedlung Habuba Kabira-Süd in Nord 
nent shoulders, and usually crosshatched incised bands and/or triangles; ${ }^{68}$ groove-and-slash decoration on jar shoulders; ${ }^{69}$ and jars with twist handles. ${ }^{70}$ In many cases, these absences or low frequencies may be ascribed to chronological factors: they are mainly Late Uruk types in an assemblage that may be predominantly Middle Uruk.

We conclude from these data that Uruk contact began earlier in the fourth millennium than the usual discussions of a "Late Uruk expansion" sug. gest. ${ }^{71}$ Much of the Uruk material from Hacinebi could be Middle Uruk in date. Although some types and features attest to the continued use of Urukrelated forms after this time, the relative paucity of many classic Late Uruk types suggests - on the basis of our present samples - that occupation was less extensive, ended early in the Late Uruk, or perhaps is only minimally preserved in this area of the site. We cannot at present, however, attribute particular excavated contexts at Hacinebi to earlier or later phases of the Uruk period. Rather, units with Uruk material - all consisting of trash deposits - contain a chronological mixture of Uruk types and attributes, regardless of stratigraphic position. In table 4 , for example, grooved round-rim jars and knife-cut bases of fine conical bowls are characteristically Middle Uruk, while droop spouts are characteristically Late Uruk. Further analysis, including examination of the distribution of temporally distinct local forms, may help to clarify this situation.

Finally, let us consider the question of where the Uruk-related pottery at Hacinebi was manufactured. Although a number of types from Hacinebi (and other sites in the region) are similar to Uruk pottery, more often than not they exhibit a combination of attributes that suggest that they are "Uruk-related" rather than truly "Uruk" in a formal or stylistic sense (see, e.g., the odd combination of decoration in fig. 23: $\mathrm{H})$. This seems to suggest local manufacture in
Table 4. Loci in Operation 1 with Substantial Quan. tities of Uruk-Related Pottery

\begin{tabular}{lcccc}
\hline & $\begin{array}{c}\text { Grooved } \\
\text { Round-Rim } \\
\text { Jars to } \\
\text { Total } \\
\text { Jar Rims }\end{array}$ & $\begin{array}{c}\text { Knife-cut to } \\
\text { String-cut } \\
\text { Bases of } \\
\text { Fine Conical } \\
\text { Bowls }\end{array}$ & $\begin{array}{c}\text { Twist } \\
\text { Handles }\end{array}$ & $\begin{array}{c}\text { Droop } \\
\text { Spouts }\end{array}$ \\
\hline 12 & $3: 104(.03)$ & $12: 28(.43)$ & 0 & 3 \\
16 & $0: 24(0)$ & $0: 8(0)$ & 0 & 0 \\
31 & $1: 63(.02)$ & $1: 4(.25)$ & 2 & 0 \\
37 & $1: 19(.05)$ & $0: 5(0)$ & 0 & 0 \\
\hline
\end{tabular}

Units are listed in stratigraphic sequence with the uppermost on top.

which there was experimentation with combinations of Uruk formal and stylistic attributes, rather than southern Mesopotamian production and export of these vessels.

So far, only one indisputable waster - of a low expanded band-rim jar - has been recorded at the site. However, both visual characteristics of the pastes used and decorative features on the pottery are distinctive in comparison to Uruk assemblages from the southern alluvial lowlands. Thus, despite the minimal direct evidence for local production, in the form of wasters or kilns, the weight of the evidence points to local manufacture of most of the Uruk-related pottery found at Hacinebi. Of course, "local production" need not imply production at the site; rather it could have occurred somewhere else in the region. Further comparative analysis, supplemented by chemical and/or mineralogical characterization of the ceramics, will be necessary to support or modify this conclusion.

DEPARTMENT OF ANTHROPOLOGY

STATE UNIVERSITY OF NEW YORK

AT BINGHAMTON

BINGHAMTON, NEW YORK 13902

\section{FLAKED STONE ASSEMBLAGES FROM HACINEBI TEPE}

\section{Henry T. Wright and Reinhard Bernbeck}

Flaked stone artifacts have four advantages for archaeologists. First, stone is durable, and survives. little altered in most archaeological sites. Second, different stone sources are usually visually or chem.

Syrien," Acta praehistorica et archaeologica 5/6 (1974-1975)

43-164, tab. 26: 85-90; Sürenhagen no. 82.

${ }^{68}$ Sürenhagen 1974-1975 (supra n. 67) tab. 7.

${ }^{69}$ Adams and Nissen fig. 68/9; Nissen (supra n. 64) tab. ically distinct, and flaked stone items can often be used to answer questions about procurement or exchange. Third, stone flaking is a subtractive process, one in which the desired form is produced by re.

\footnotetext{
$37 c$.

70 Adams and Nissen figs. 30: k-1, 37.9, and 47.2.

${ }^{71}$ See also Sürenhagen $31-33$ for a similar conclusion.
} 
moving small pieces of raw material. Manufacture, resharpening, and discard of the broken tool leave distinctive by-products. Fourth, hafting and utilization of stone tools leave traces on the tool indicating the activities in which it was used.

This preliminary study takes advantage of all these potentials, focusing on secondary debris, i.e., trash thought to have been moved only once, which was at least partially screened through a $0.6 \cdot \mathrm{mm}$ mesh. This should insure comparability from locus to locus within Hacınebi and with other fourth-millennium sites from which flaked stone samples have been similarly recovered. The data on flaked stone samples have been recorded in a manner comparable to the system used at Tepe Farukhabad and Tepe Sharafabad in southwestern Iran and at the Uruk Mound at Tell Abu Salabikh in southern Iraq. ${ }^{72}$

\section{RAW MATERIAL SOURCES}

Hacınebi Tepe sits on a terrace above the Euphrates cut into Eocene chalk, but veneered with lenses of gravel marking former stream channels. These gravels contain rolled Levallois flakes and cores and may be of early Upper Pleistocene age. They also contain pebbles of limestone, basalt, and siliceous stones, here termed "flint." Many of these pebbles still have the form of the original nodule, and have a chalky exterior, so they cannot have been transported any great distance from their bedrock sources. We examined geological contexts on the terraces and hills up to a kilometer south, east, and north of the site and the modern village of Ugurcuk. We recognized six local flint varieties. They can be viewed as variants within a population, but the grainy medium-textured varieties seem to occur in a larger raw material "package" and to have different work. ing properties.

Medium Banded Cream and Tan. Most commonly found is a grainy- to fine-textured material, thin even flakes of which are opaque. The formation of the nodule created concentric bands of cream (Munsell 10YR 6/1 to 7/1) and tan (Munsell 10YR 5/2 ["gray. brown"] to 10YR 6/2 ["light brown"] to 7.5YR 6/2 ["pinkish gray"]). Chalky exteriors are still evident on $70 \%$ of the nodules from local gravels, suggesting a nearby origin. This material is particularly common about $900 \mathrm{~m}$ northeast of the village. One cobble $-0.24 \times$ $0.15 \times 0.11 \mathrm{~m}-$ had recently been flaked there, per-

\footnotetext{
72 Wright (supra n. 65); Wright et al. (supra n. 10); H. Wright, R. Redding, and S. Pollock, "Monitoring Interannual Variability: An Example from the Period of Early State De. velopment in Southwestern Iran," in P. Halstead and J. O'Shea eds., Bad Year Economics: Cultural Responses to Risk
}

haps to make threshing sled blades. This cobble could have produced some of the large blades found at Hacınebi Tepe.

Medium Banded Gray. This rare variant is similar to the above, except that the bands are gray (Munsell 10YR 7/1) and white (10YR 8/1), presumably because little iron is present in the material. All examples noted lack a chalky cortex.

Medium White. This flint is similar in texture and color to the above two types, but lacks banding. Cortical flakes show it occurs as large nodules. None were found near Hacınebi, so it is possible that these cobbles were imported from other localities.

Fine Translucent Brown. This flint is the second most common material found. It is fine-textured and thin flakes are translucent. The colors vary from light brown (Munsell 7.5YR 6/3) to brown (7.5YR 5/4) to dark brown or "chocolate" (7.5YR 4/2). This flint commonly occurs as small nodules with irregular or elongated form, all of which still had a chalky cortex. Some examples were found on the hills east and north of the village, rather than in the gravels, and may be weathering from local chalk. The elongated form is common in gravels near Şadı Hüyük, a fourthmillennium center $18 \mathrm{~km}$ down the Euphrates, ${ }^{73}$ and the Hacinebi examples may indicate a connection with that area.

Fine Translucent Tan. This flint is similar in texture to the above types, except that it is lighter (10YR $7 / 4$ ["very pale brown"]). It was not found in our examination of local gravels, but is probably local.

Fine Pink. This is a fine-textured opaque material, sometimes with bands or mottling. While some reddened cherts may have been produced by deliber. ate heat treatment, several naturally red examples were found in gravels south and east of the village.

Three other materials, two probably imported, occurred.

Fine Dark Gray. This is an Eocene flint similar to the local materials, but not previously found in the area of Hacinebi Tepe. It sometimes has fine band. ing or mottling. Some examples approach the tabular "Fine Mottled Gray" commonly imported into southern Iraq during the fourth and third millennia, the source of which was probably in central Syria. $^{74}$

Obsidian. The nearest reported source of this volcanic stone is near Bingöl, $160 \mathrm{~km}$ northeast of

and Uncertainty (Cambridge 1989) 106-13; S. Pollock, C. Steele, and M. Pope, "Investigations on the Uruk Mound, Abu Salabikh, 1990," Iraq 53 (1991) 59-68.

${ }^{73}$ Algaze et al. (supra n. 16) 53 and map fig. 8 .

${ }^{74}$ Wright (supra n. 65) 272. 


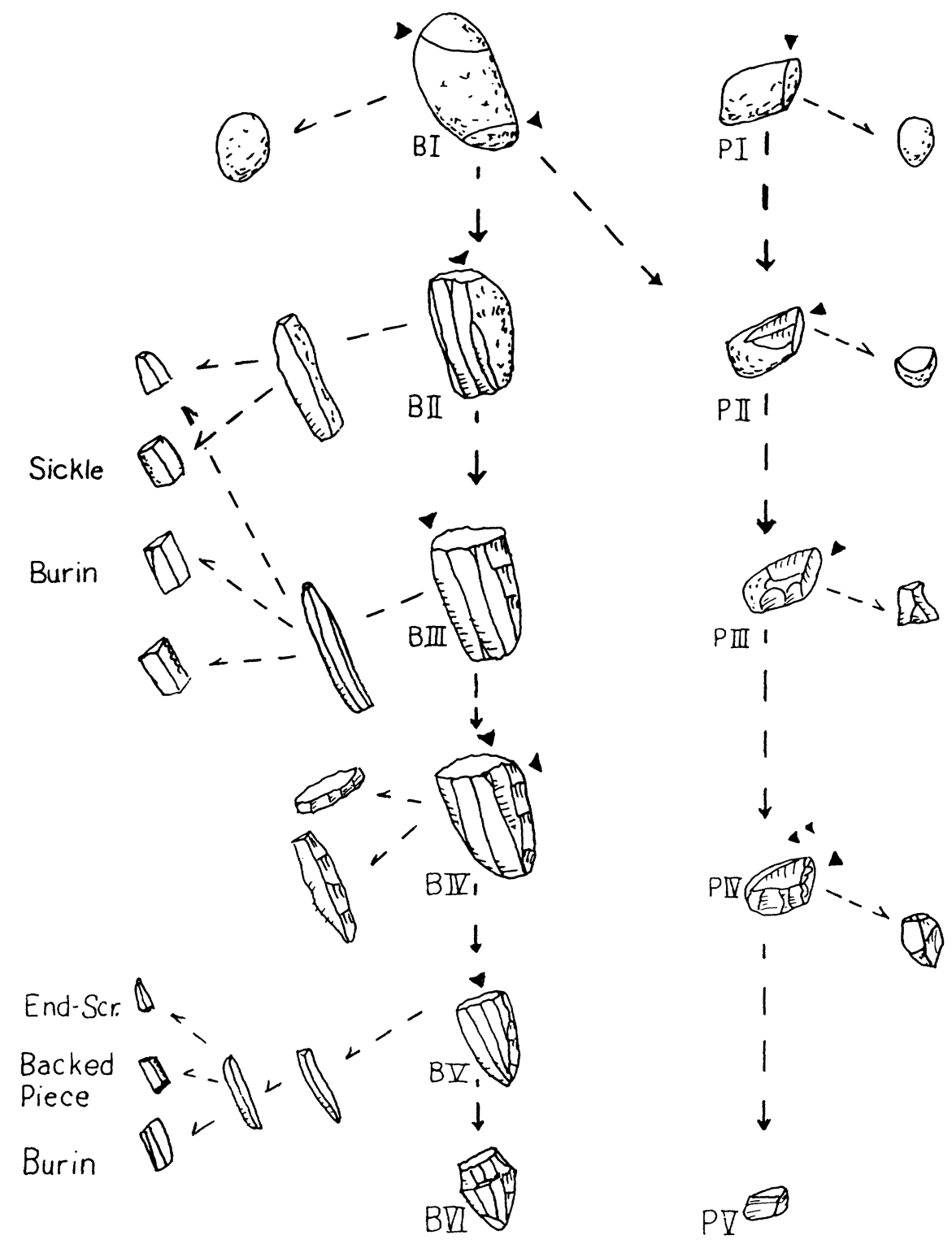

Fig. 25. Blade (left) and flake (right) manufacturing trajectories

Hacınebi. Only a few blades and flakes were found. One is of the greenish obsidian typical of Nemrut Dağ near Lake Van. The others are of a black obsidian, the sources of which can only be determined with chemical analysis.

Burnt Flint. These items are darkened, cracked, and covered with hemispherical "potlid" scars. They are probably local cherts damaged beyond recognition.

Various unique materials were also noted. Discussion here would contribute little.

\section{PRODUCTION OF FLAKED STONE TOOLS}

The sequence of production at Hacınebi Tepe had two trajectories, one producing blade cores from larger flint nodules, and then blade tools from these cores, and the other producing small polyhedral cores from small flint nodules or fragments, and then flake tools from these cores (fig. 25). The actual tra jectories are complex and merit expanded discussion.

\section{THE BLADE TRAJECTORY}

To create blades, the artisan first selected a 15-30 $\mathrm{cm}$ long cobble and removed a large cortical flake from one or both ends with blows from the side (fig. 25: BI). Few such flakes occur in the samples examined, and it is possible that this was usually done at the stone source to "test" the nodule. Next, using one or both of these initial flake removal surfaces as platforms, the artisan removed a series of large 


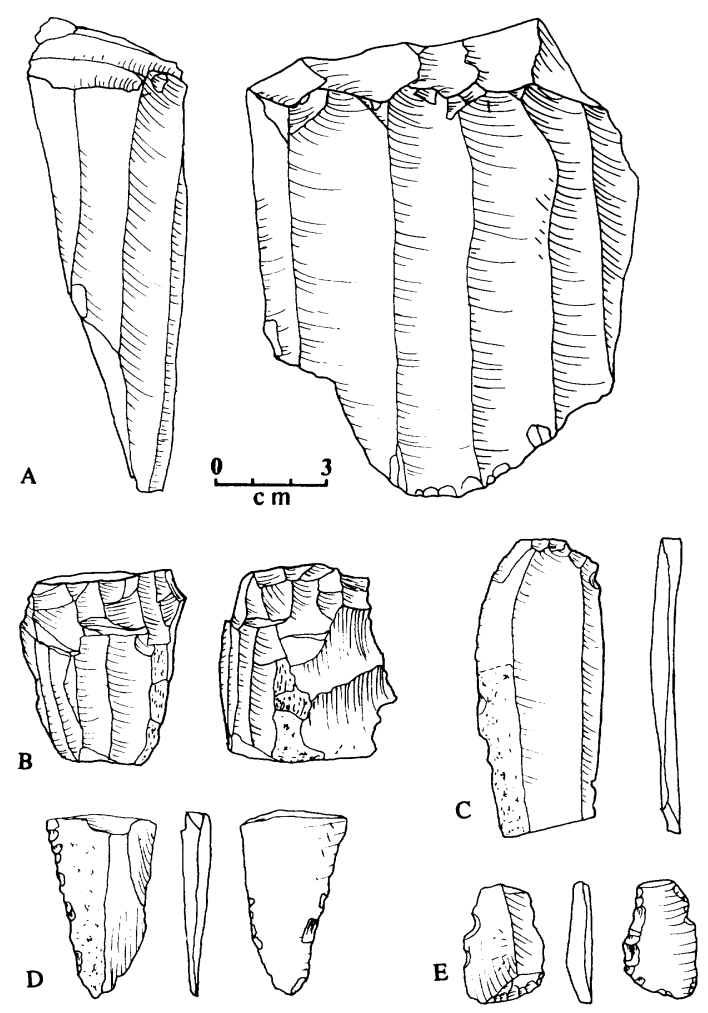

Fig. 26. By-products of blade production from operation 1, Late Chalcolithic phase A (catalogue on opposite page)
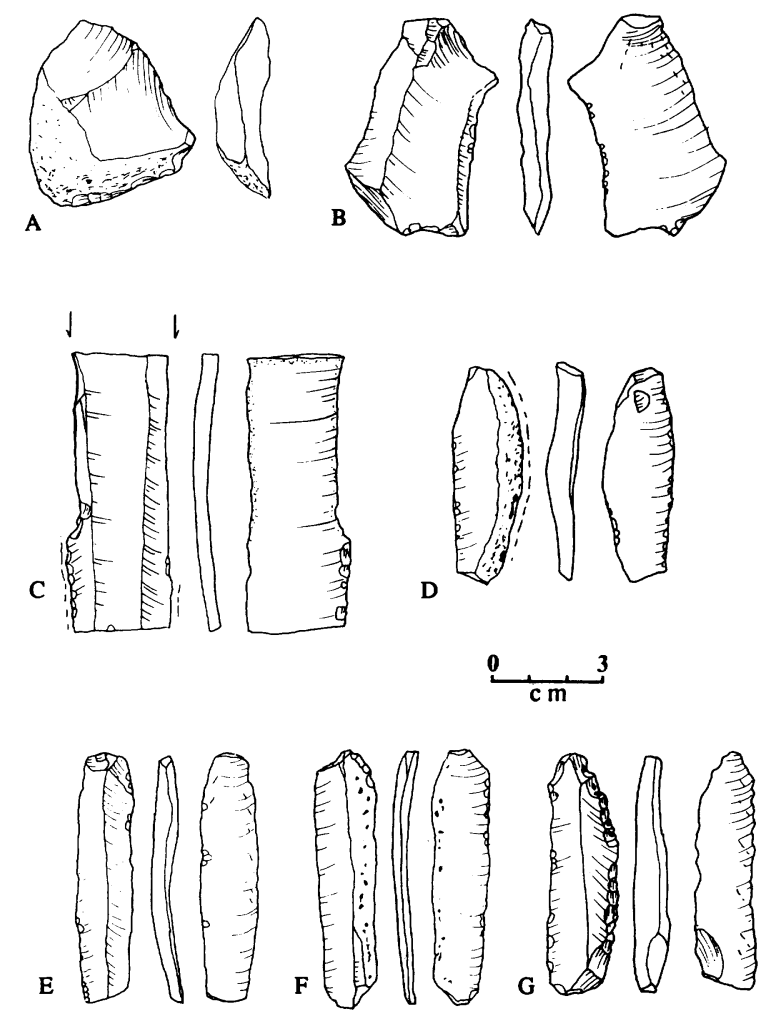

Fig. 27. Blade tools from operation 1, Late Chalcolithic phase B (catalogue on opposite page)
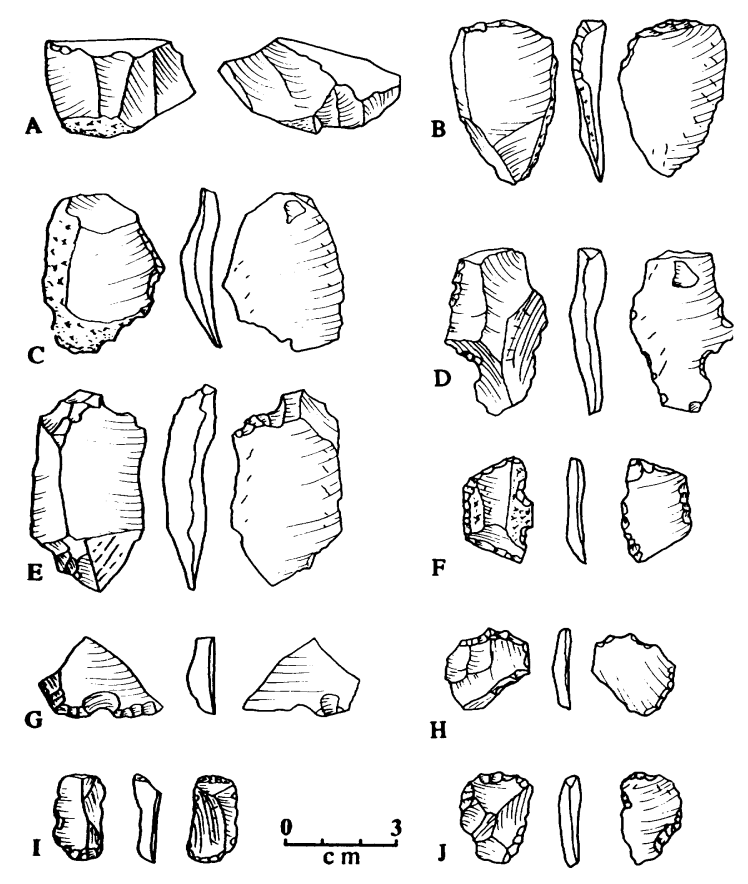

Fig. 28. Flake core, flakes, and flake tools from operation 2, Late Chalcolithic phase A (catalogue on opposite page)
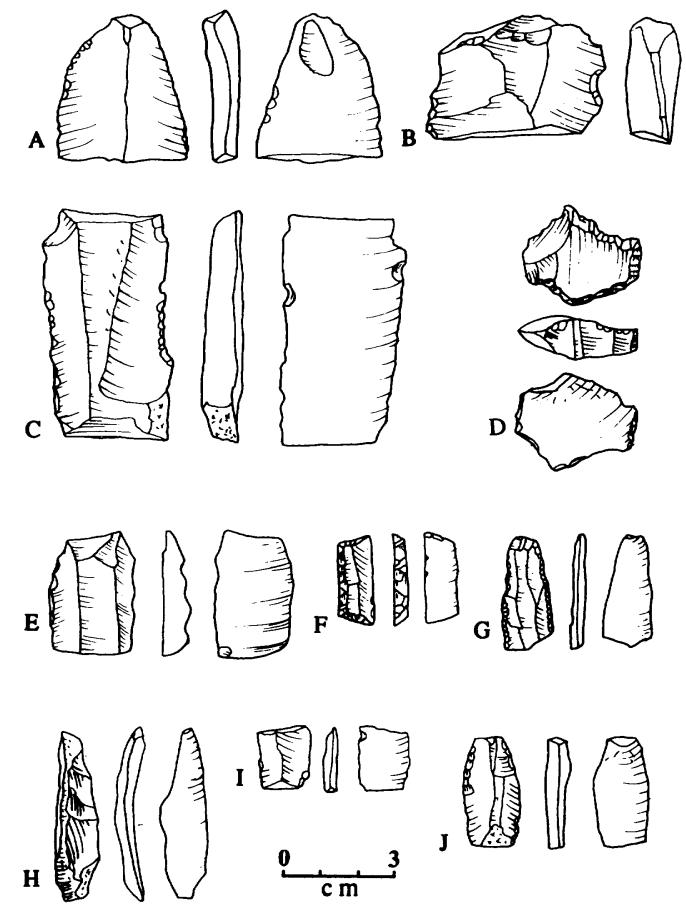

Fig. 29. Blades and blade tools from operation 2, Late Chalcolithic phase A (catalogue on opposite page) 

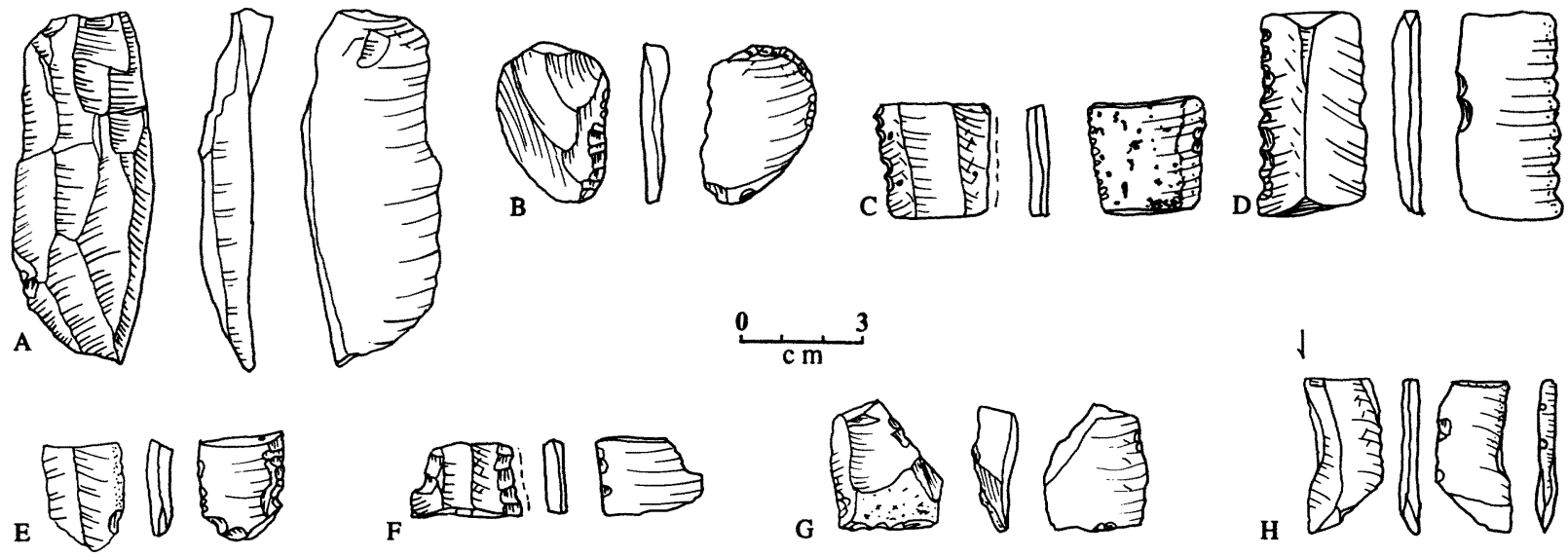

Fig. 30. Blades and blade tools primarily from operation 5, Late Chalcolithic phase B (catalogue below)

Fig. 26 (cont.). A. Face of large blade core, op. 1, loc. 88, lot 100, HN1103:L1, Medium Banded Cream and Tan flint, with pink portion, suggesting heat treatment. B. Exhausted blade core, op. 1, loc. 88, lot 100, HN1103:L14, Medium Banded Gray flint, with pink portion, suggesting heat treatment. C. Large cortical blade, op. 1, loc. 88, lot 100, HN1103:L2, Medium Banded Cream and Tan flint. D. Distal segment of cortical blade, op. 1, loc. 88, lot 100, HN1103:L15, Fine Pink flint. E. End scraper on ridge removal blade segment, op. 1, loc. 88, lot 100, HN1103:L5, Medium Banded Cream and Tan flint.

Fig. 27 (cont.). A. Secondary cortical flake, op. 1, loc. 12, lot 10, HN210:L4, Medium Banded Cream and Tan flint. B. Early stage large blade with possible distal use as a perforater, op. 1, loc. 12, lot 10, HN210:L22, Medium White flint. C. Medial segment of large blade with burin removals, op. 1, loc. 30, lot 30, HN337:L22, Medium White flint. Note polish on edges of ventral surface. Yellow deposit on ventral surface not symbolized. D. Cortical blade, op. 1, loc. 12, lot 10, HN210:L28, Fine Translucent Brown flint. Note bitumen haft traces. E. Blade, op. 1, loc. 12, lot 10, HN210:L24, Fine Pink flint. F. Blade, op. 1, loc. 12, lot 10, HN210:L30, Medium Banded Cream and Tan flint. Note bitumen haft traces. G. Utilized blade, op. 1, loc. 12, lot 10, HN210:L31, Medium Banded Gray flint. Note bitumen haft traces.

Fig. 28 (cont.). A. Small polyhedral core, op. 2, loc. 26, lot 67, HN885:L2, Fine Pink flint. B. Flake with faceted platform, op. 2, loc. 26, lot 65, HN868:L2, Medium Banded Cream and Tan flint. C. Retouched cortical flake, op. 2, loc. 26, lot 58, HN729:L1, Medium Banded Gray flint. Note marginal retouch and utilization. D. Flake with plain platform, op. 2, loc. 26, lot 56, HN721:L3, Fine Translucent Brown flint. Note notch. E. Flake, op. 2, loc. 26, lot 58, HN729:L2, Medium Banded Gray flint. Note distal utilization. F. Backed and truncated cortical flake, op. 2, loc. 26, lot 58, HN729:L4, Fine Translucent Brown flint. G. Scraper bit fragment, op. 2, loc. 26, lot 56, HN723:L11. Fine Pink flint. H. Small denticulate flake, op. 2, loc. 26, lot 58, HN729:L5, Fine Translucent Brown flint. I. Small endscraper, op. 2, loc. 26, lot 63, HN854:L9, Fine Translucent Brown flint. J. Small retouched flake, op. 2, loc. 26, lot 67, HN884:L4, Fine Translucent Brown flint. Note distal notch.

Fig. 29 (cont.). A. Proximal segment of large blade, op. 2, loc. 26, lot 63, HN854:L4, Medium White flint. Yellow residue on ventral face. B. Proximal segment of large blade, op. 2, loc. 26, lot 61, HN737:L1, Medium Banded Cream and Tan flint. C. Medial segment of large blade, op. 2, loc. 26, lot 55, HN717:L2, Medium White flint. Yellow residue on left dorsal edge. D. Top rejuvenation flake from small blade core, op. 2, loc. 26, lot 65, HN877:L1, Fine Translucent Brown flint. E. Medial segment of blade, op. 2, loc. 26, lot 55, HN717:L1, Medium Banded Cream and Tan flint. F. Backed and truncated medial blade segment, op. 2, loc. 26, lot 65, HN868:L9, Fine Translucent Tan flint. G. Segment of blade with fine marginal backing, op. 2, loc. 26, lot 56, HN721:L10, Fine Dark Gray flint. H. Ridge removal blade, op. 2, loc. 26, lot 56, HN721:L4, Fine Translucent Tan flint. I. Medial segment of blade, op. 2, loc. 26, lot 56, HN723:L6, Fine Translucent Tan flint. J. Segment of blade with irregular marginal backing, op. 2, loc. 26, lot 61, HN737:L5, Fine Translucent Brown flint.

Fig. 30 (cont.). A. Face of blade core, op. 5, loc. 6, lot 13, HN1336:L7, Medium Banded Cream and Tan flint, partly pink, suggesting heat treatment. B. Flake with faceted platform, op. 5, loc. 22, lot 38, HN1513:L10, Fine Translucent Brown flint. Note retouch. C. Plain sickle on medial segment of large blade, op. 5, loc. 20, lot 33, HN1391:L1, Medium Banded Cream and Tan flint. Note bitumen traces and sheen on left dorsal and ventral edges. D. Denticulate sickle on medial segment of large blade, op. 5, loc. 22, lot 38, HN1513:L7, Medium White flint. Slight sheen on left ventral edge. E. Plain sickle on distal segment of blade, op. 5, loc. 22, lot 41, HN1501:L2, Medium Banded Cream and Tan flint. Note bitumen trace and sheen on left dorsal and ventral edges. F. Medial segment of large blade with heavy backing, op. 5, loc. 22, lot 41, HN1510:L3, Medium White flint. Note notch. G. Distal segment of large blade, op. 5, loc. 22, lot 38, HN1513:L6, Medium White flint. H. Burin on distal blade segment, op. 2, loc. 29, lot 70, HN926:L5, Medium Banded Cream and Tan flint. Note polish on right edge of ventral face. 
cortical blades from the longer faces of the nodule (fig. 25: BII). These cortical blades could be used with minimal modification (fig. 26: D), or broken into proximal, medial, and distal segments and made into tools as described below. The core faces were further shaped by the removal of flakes and rough blades (fig. 27: B), which increased in evenness until continuous blade removal of large, so-called "Canaanean" blades was possible with only slight modifications of the platform before each removal. The face of a smaller core at such a stage - presumably removed by accident - is illustrated (fig. 28: A). The working of larger blade cores (fig. 25: BIII) involved a technique to detach large blades from faces with angles between platform and face of up to $95^{\circ}$, leaving pronounced bulbs of percussion. Perhaps the core was held in a vise and/or bound, with the striking force applied with a special hammer or a levered punch. This stage is represented by the face of such a core (fig. 26: A), probably removed by accident, and by segments of large blades. Proximal blade segments were used with little modification (fig. 29: A-B). Medial blade segments were either used unmodified (fig. 29: C, E) or as sickles (fig. 30: C-D), or they were modified into such formal tools as backed pieces (fig. 30: F) or burins (fig. 27: C). Distal blade segments were also used unmodified (fig. 30: G) or as sickles (fig. 30: E), or were modified into formal tool types. After removing a number of blades, the artisan would have had to rework or "rejuvenate" the blade core (fig. 25: BIV). On the one hand, the face may have become flat. In this event, it could be rounded and extended by removing "crested blades" or ridge re- moval blades from either side of the face. These can be used without modification (fig. 29: H), or broken into segments and modified, for example as an endscraper (fig. 26: E) or burin (fig. 30: H). On the other hand, the platform of the core may have become damaged or may have required a better striking angle (one closer to about $75^{\circ}$ ). The artisan could attempt to remedy this with a blow to the side of the core, removing a "platform rejuvenation flake" (fig. 29: D). The now-reduced blade core-or blade cores initially produced from smaller pieces of Fine Translucent flint-could be worked as described above, producing small blades used whole (figs. 27: E-G, 29: E), broken into segments (fig. 29: I), or backed (fig. 29: F-G). The rejuvenation procedures could be repeated, but eventually the blade core became too small to work, and was discarded (fig. 26: B) or used as a flake core. A histogram of blade segment widths shows that two discrete sizes were produced (fig. 31).

\section{THE FLAKE TRAJECTORY}

To create flakes, the artisan first selected a cobble $10-20 \mathrm{~cm}$ long and removed a cortical flake from one end (fig. 25: PI). A few pieces in the collection, none illustrated, attest to this initial step being undertaken at Hacınebi. Since such small nodules occur in the gravels near, and even under, the site, and the pieces are small and easily brought home, this is not surprising. If the piece was adequate, the scar of the initial flake became the platform for striking successive secondary cortical flakes (fig. 28: A). The resulting prepared core (fig. 25: PII; fig. 28: A) is easily

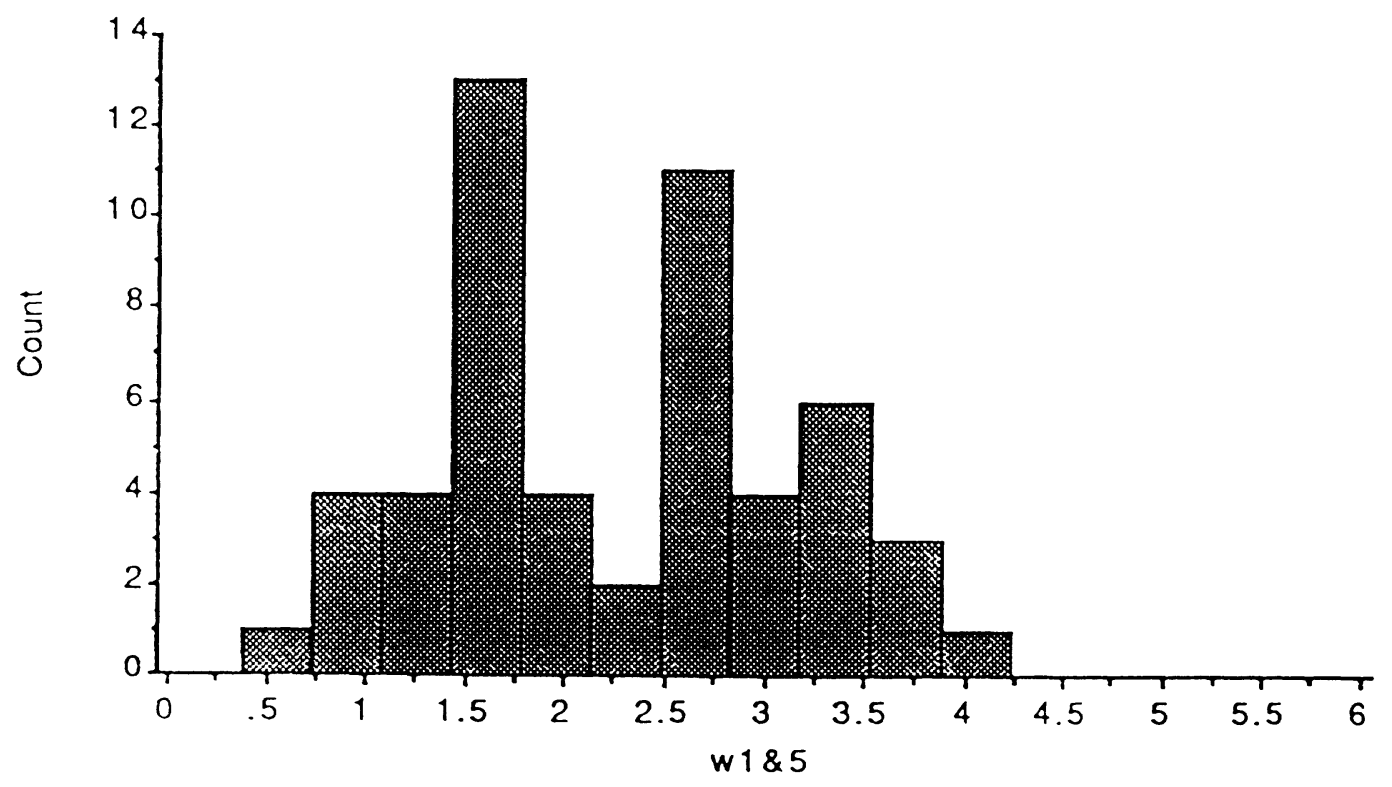

Fig. 31. Histogram of widths of a sample of blades from operations 1 and 5 
mistaken for a chopping tool, and indeed there is no reason why it could not have been used for chopping or scraping. Continued working of this core (fig. 25: PIII) would result in removal of flat flakes that could be used with little modification (fig. 28: D-E). Careful shaping of the core face by flaking from the sides and base, and trimming of the platform could create a disk-like core, and striking of roughly oval or triangular flakes from such a core (fig. 25: PIV) provides a flake blank like a small Levallois flake, which can be used without further modification (fig. 29: B) or modified into such finished tools as sidescrapers (fig. 28: G), endscrapers (fig. 28: I), or denticulates (fig. 28: $\mathrm{H}, \mathrm{J}$ ). Intact examples of such disk cores have not been noted, but much remains to be learned from the study of the often-ignored non-blade cores. Eventually, these cores are also reduced to pieces of material too small to further flake, and the exhausted piece would be discarded (fig. 25: PV).

\section{IMPLEMENTS AND TOOLS}

Most of the stone artifacts were used with little modification, either held in the hand or fixed in a handle. These are properly called "implements." Some stone items, however, were modified in patterned ways to create formal "tools." Two kinds of implements are notable:

Utilized blades and blade segments. These large medial segments or near-complete blades are backed or ground on one edge and show heavy bifacial utilization chipping on the other edge (figs. 27: D-G, 30: C). Traces of bitumen adhesive or a yellow residue, perhaps a trace of another kind of adhesive, were noted.

Sickle blades. These are typically larger blade seg. ments with traces of polish on one edge. Most have traces of bitumen hafting adhesive. One has denticu. late retouch (fig. 30: D), but most are plain (fig. 30: C, E).

Five kinds of formal tools are notable:

Endscrapers. These have a rough convergent re. touch on the end of a small blade segment or flake (figs. 26: E, 28: I). Crushing and chipping on the mar. gins may result from the application of pressure in a socketed handle.

Sidescrapers. Several flake edges have steep serial retouch (fig. 28: G). None of these are well preserved enough to discuss hafting or use.

Burins. One or more blade edges have been re. moved by a burin blow to a break (figs. 27: C, 30: $\mathrm{H})$. In both cases there is polish on the flat ventral or interior face of the blade, as if it was used for whit tling. One example has a yellow residue, perhaps evidence of a hafting adhesive.

Backed and truncated pieces. These are small medial blade segments or blade-like flakes that have been backed on three sides to produce a trapezoidal piece (figs. 28: f, 29: F).

Denticulates. These are small flakes that have mul. tiple adjacent notches, each made by several small flakes (fig. 28: $\mathrm{H}, \mathrm{J}$ ). It is not clear whether these were deliberately made tools, or simply flakes trampled and crushed underfoot.

\section{ORGANIZATION OF TECHNOLOGICAL ACTIVITY}

We examined samples of chipped stone debris from well-defined contexts from three separate areas of Hacinebi Tepe. Though items with evidence of specific use are rare, there are nonetheless notable patterns of spatial variation in the frequencies of implements and tools (tables 5-6).

Operations 1 and 4 comprise an area of massive compound and building walls on the northeastern edge of the site. The later layers have a majority of

Table 5. Hacınebi Chipped Stone Industrial Debris Density (per cubic meter)

\begin{tabular}{|c|c|c|c|c|c|c|c|c|c|c|c|c|c|c|c|c|c|c|c|c|c|c|c|c|}
\hline \multirow[b]{3}{*}{$\begin{array}{l}\text { Opera- } \\
\text { tion }\end{array}$} & \multirow[b]{3}{*}{ Locus } & \multirow{3}{*}{$\begin{array}{c}\text { Exca- } \\
\text { vated } \\
\text { Volume }\end{array}$} & \multirow[b]{3}{*}{$\begin{array}{c}\text { Total } \\
\text { Ct. }\end{array}$} & \multirow[b]{3}{*}{$\begin{array}{l}\text { Wt. } \\
\text { (g) }\end{array}$} & \multicolumn{20}{|c|}{ Flint Types } \\
\hline & & & & & \multicolumn{4}{|c|}{$\mathrm{MBC} / \mathrm{T} / \mathrm{G}$} & \multicolumn{4}{|c|}{ MW } & \multicolumn{3}{|c|}{$\mathrm{FTB} / \mathrm{T}$} & \multicolumn{4}{|c|}{ FP } & \multicolumn{4}{|c|}{ FDG } & \\
\hline & & & & & $\begin{array}{l}\mathrm{Crt} / \\
\mathrm{Chk}\end{array}$ & $\begin{array}{ll}\mathrm{Cr} & \mathrm{I} \\
\mathrm{Rjv} & \mathrm{D}\end{array}$ & $\begin{array}{l}\text { Flk } \\
\text { Deb I }\end{array}$ & $\begin{array}{l}\text { Bld C } \\
\text { Deb C }\end{array}$ & $\begin{array}{l}\mathrm{Crt} / \mathrm{C} \\
\text { Chk R }\end{array}$ & $\begin{array}{l}\mathrm{Cr} \\
\mathrm{Rjv} \mathrm{I}\end{array}$ & $\begin{array}{l}\text { Flk B } \\
\text { Deb D }\end{array}$ & $\begin{array}{l}\text { Bld } \mathrm{Cr} \\
\text { Deb } \mathrm{Cr}\end{array}$ & $\begin{array}{l}\text { Crt/ } \\
\text { Chk R }\end{array}$ & $\begin{array}{l}\text { Cr Flk } \\
\text { Rjv Deb }\end{array}$ & $\begin{array}{l}k \text { Bld } \\
\text { b Deb }\end{array}$ & $\begin{array}{l}\text { Crt/ } \\
\text { Chk R }\end{array}$ & $\begin{array}{ll}\mathrm{Cr} & \mathrm{F} \\
\mathrm{Rj} & \mathrm{D}\end{array}$ & $\begin{array}{l}\text { Flk B } \\
\text { Deb D }\end{array}$ & & $\begin{array}{l}\mathrm{Crt} / \mathrm{C} \\
\text { Chk R }\end{array}$ & & lk Bld & & ther \\
\hline $1 \mathrm{up}$ & 12,16 & $7.0 \mathrm{~m}^{3}$ & 48 & 438 & 12 & 1 & 11 & 2 & 0 & 0 & 2 & 1 & 1 & 0 & 0 & 3 & 0 & 1 & 0 & 0 & 0 & 1 & 0 & 4 \\
\hline 2 up & 18,20 & $3.0 \mathrm{~m}^{3}$ & 70 & 421 & 8 & 2 & 7 & 3 & 1 & 1 & 4 & 1 & 4 & 111 & 2 & 0 & 1 & 2 & 0 & 0 & 0 & 5 & 0 & 14 \\
\hline 5 up & 20,22 & $0.5 \mathrm{~m}^{3}$ & 63 & 204 & 8 & 0 & 8 & 1 & 0 & 0 & 4 & 1 & 6 & 17 & 1 & 2 & $\begin{array}{ll}0 & 1\end{array}$ & 10 & 0 & 0 & 0 & 0 & 0 & 0 \\
\hline 6 up & 13 & $0.2 \mathrm{~m}^{3}$ & 41 & 166 & 2 & 2 & 6 & 2 & 0 & 0 & 4 & 0 & 5 & 0 & 1 & 2 & 0 & 3 & 0 & 0 & 0 & 0 & 0 & 0 \\
\hline $2 \mathrm{mid}$ & $26,28,29$ & $5.5 \mathrm{~m}^{3}$ & 114 & 218 & 9 & 6 & 15 & 1 & 0 & 0 & 3 & 11 & 12 & 12 & 2 & 2 & 3 & 4 & 0 & 1 & 0 & 3 & 1 & 3 \\
\hline $5 \mathrm{mid}$ & 31,42 & - & 103 & 472 & 3 & 1 & 9 & 0 & 1 & 0 & 3 & 21 & 12 & $\begin{array}{ll}0 & 17\end{array}$ & 3 & 7 & 11 & 12 & 0 & 1 & 1 & 6 & 0 & 36 \\
\hline
\end{tabular}

$\mathrm{MBC} / \mathrm{T} / \mathrm{G}=$ Medium Banded Cream and Tan or Gray; MW = Medium White; FTB $/ \mathrm{T}=$ Fine Translucent Brown; FP = Fine Pink; FDG = Fine Dark Gray; Bld Deb = Blade Debitage; Crt/Chk = Cortical Flake/Chunk; Cr Rjv = Core Rejuvenation; Flk Deb $=$ Flake Debitage 
Table 6. Hacinebi Chipped Stone Tools and Implements

\begin{tabular}{|c|c|c|c|c|c|c|c|c|c|c|c|}
\hline \multirow[b]{2}{*}{$\begin{array}{l}\text { Opera- } \\
\text { tion }\end{array}$} & \multirow[b]{2}{*}{ Locus } & \multicolumn{5}{|c|}{ Blade Tools } & \multicolumn{4}{|c|}{ Flake Tools } & \multirow[b]{2}{*}{ Total } \\
\hline & & $\begin{array}{l}\text { Utilized } \\
\text { Blade }\end{array}$ & $\begin{array}{c}\text { Seg- } \\
\text { ment }\end{array}$ & Sickle & Burin & Other & $\begin{array}{l}\text { Utilized } \\
\text { Flake }\end{array}$ & $\begin{array}{l}\text { Dent.l } \\
\text { Notch }\end{array}$ & $\begin{array}{l}\text { Grat. } \\
\text { toir }\end{array}$ & Racloir & \\
\hline $1 \mathrm{up}$ & 12,30 & 5 & 2 & 1 & 1 & - & 1 & 1 & - & 1 & 12 \\
\hline 2 up & 18,20 & - & 8 & - & - & 1 trunc & - & 1 & 1 & 4 & 15 \\
\hline 5 up & 20,22 & - & 2 & 3 & - & - & - & 2 & - & 1 & 8 \\
\hline $2 \mathrm{mid}$ & $26,28,29$ & 3 & 4 & - & 1 & $\begin{array}{l}1 \text { trunc } \\
1 \text { bakd }\end{array}$ & 4 & 8 & 1 & 2 & 25 \\
\hline $5 \mathrm{mid}$ & 31,42 & - & 5 & - & - & - & 1 & 2 & - & - & 8 \\
\hline 1 lo & 88,93 & 2 & 3 & - & - & - & 2 & - & 1 & 1 & 9 \\
\hline
\end{tabular}

ceramics of southern Mesopotamian affinity. Here were recovered the best samples of primary flaking debris found at Hacinebi, though all were in tertiary fill, rather than in primary or secondary contexts. Measured blades show much greater variation in thickness (fig. 32), which is expected in a manufacturing area, but also might be expected in more mixed tertiary fills. These assemblages have higher frequencies of large utilized blade segments with bitumen hafts, probably used as knives. Sickles and other small flake and blade tools are rare.

Operation 2 is an area of substantial Late Chalcolithic buildings with domestic debris on the southeastern edge of the site, characterized by debitage and small flake or blade tools, but primary flaking debris is rare and sickles are absent from the analyzed samples. Operation 5 is an area of modest Late Chalcolithic buildings with domestic debris on the west end of the site with some primary flaking debris, and a diversity of sickles. The only repeatedly occurring small tool type (if it is a tool) is the denticulate.

\section{ORGANIZATION OF PROCUREMENT AND EXCHANGE}

The earlier samples examined so far show little significant variation in the proportions of raw ma. terial types represented (by weight), while the later samples exhibit clear differences (table 7). In phase A, the local cherts - the medium-textured banded flints and the finer translucent flints-occur in similar frequencies in all areas studied. Similarly the one consistently occurring minor material that may be imported-Fine Dark Gray flint-occurs in all areas. One surprising occurrence is that of obsidian in operation 5, the area of modest housing. These are mostly flakes from various stages of core working, suggesting that a few cores were obtained and worked by families of modest means.

In the later times (phase B), local flints show vari.

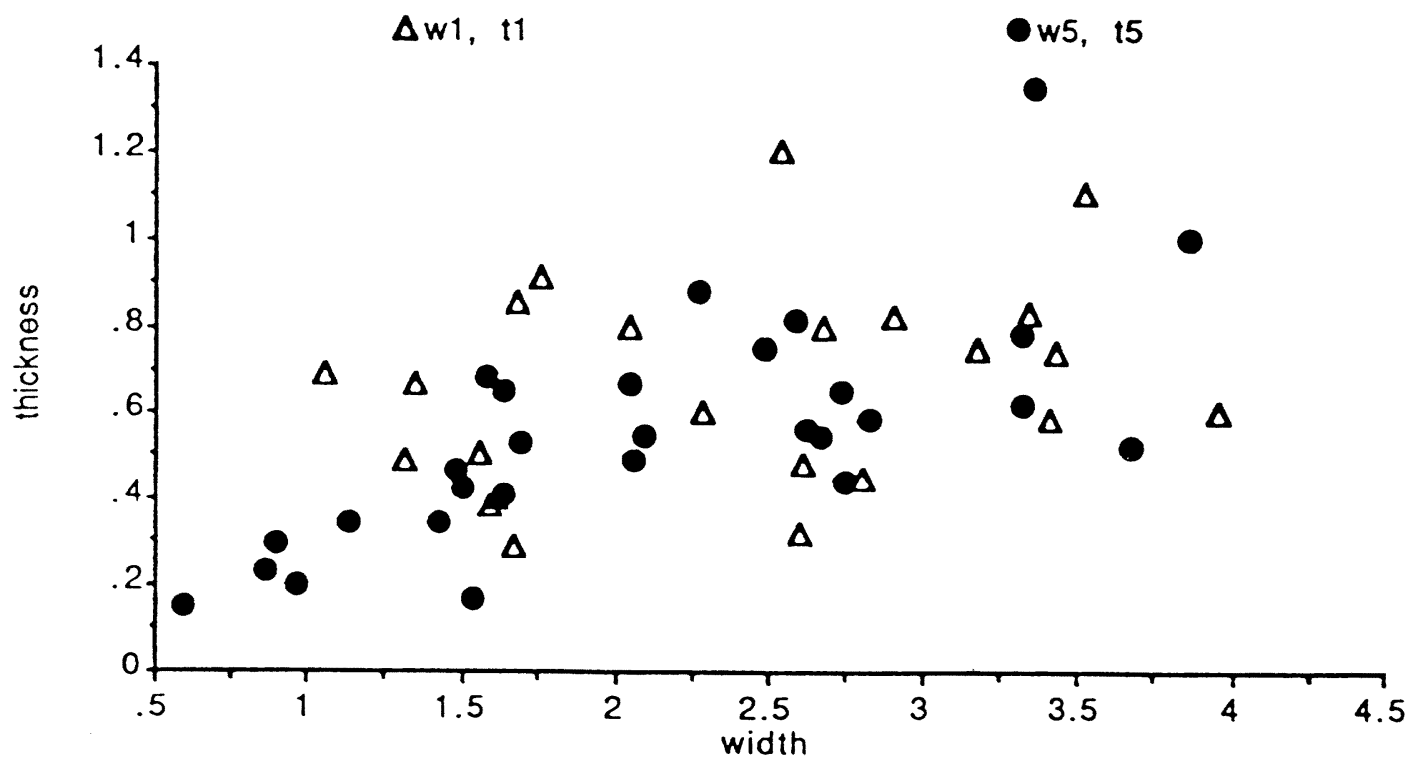

Fig. 32. Scatter plot showing width/thickness ratios for blades from operations 1 and 5 (op. 1: $\mathrm{r}=.291$; op. $5: \mathrm{r}=.726$ ) 
Table 7. Hacınebi Chipped Stone Raw Material by Weight (g)

\begin{tabular}{|c|c|c|c|c|c|c|c|c|c|}
\hline \multirow[b]{2}{*}{ Operation } & \multirow[b]{2}{*}{ Locus } & & \multicolumn{7}{|c|}{ Flint Types } \\
\hline & & & $\mathrm{MBC} / \mathrm{T} / \mathrm{G}$ & MW & $\mathrm{FTB} / \mathrm{T}$ & FP & FDG & Other & Burnt \\
\hline 1 up & 12,16 & $\begin{array}{r}\text { Wt. } \\
\%\end{array}$ & $\begin{array}{c}367 \\
83.8\end{array}$ & $\begin{array}{l}20 \\
4.6\end{array}$ & $\begin{array}{l}15 \\
3.4\end{array}$ & $\begin{array}{l}23 \\
5.2\end{array}$ & $\begin{array}{l}0 \\
-\end{array}$ & $\begin{array}{l}4 \\
0.9\end{array}$ & $\begin{array}{l}9 \\
2.1\end{array}$ \\
\hline 2 up & 18,20 & $\begin{array}{r}\text { Wt. } \\
\%\end{array}$ & $\begin{array}{c}251 \\
57.7\end{array}$ & $\begin{array}{l}40 \\
9.2\end{array}$ & $\begin{array}{l}97 \\
22.3\end{array}$ & $\begin{array}{c}16 \\
3.7\end{array}$ & $\begin{array}{l}6 \\
1.4\end{array}$ & $\begin{array}{c}14 \\
3.2\end{array}$ & $\begin{array}{c}11 \\
2.5\end{array}$ \\
\hline 5 up & 20,22 & $\begin{array}{r}\mathrm{Wt} . \\
\%\end{array}$ & $\begin{array}{l}61 \\
29.9\end{array}$ & $\begin{array}{l}29 \\
14.2\end{array}$ & $\begin{array}{l}92 \\
45.1\end{array}$ & $\begin{array}{l}16 \\
7.8\end{array}$ & $\begin{array}{l}0 \\
-\end{array}$ & $\begin{array}{l}0 \\
-\end{array}$ & $\begin{array}{l}6 \\
2.9\end{array}$ \\
\hline 6 up & 13 & $\begin{array}{r}\text { Wt. } \\
\%\end{array}$ & $\begin{array}{l}117 \\
70.5\end{array}$ & $\begin{array}{c}10 \\
6.0\end{array}$ & $\begin{array}{l}19 \\
11.4\end{array}$ & $\begin{array}{c}11 \\
6.6\end{array}$ & $\begin{array}{l}0 \\
-\end{array}$ & $\begin{array}{l}0 \\
-\end{array}$ & $\begin{array}{l}9 \\
5.4\end{array}$ \\
\hline $2 \mathrm{mid}$ & $26,28,29$ & $\begin{array}{r}\mathrm{Wt} . \\
\%\end{array}$ & $\begin{array}{c}427 \\
52.0\end{array}$ & $\begin{array}{c}21 \\
2.6\end{array}$ & $\begin{array}{l}129 \\
15.7\end{array}$ & $\begin{array}{c}161 \\
19.6\end{array}$ & $\begin{array}{l}25 \\
3.0\end{array}$ & $\begin{array}{l}3 \\
0.4\end{array}$ & $\begin{array}{l}55 \\
6.7\end{array}$ \\
\hline $5 \mathrm{mid}$ & 31,42 & $\begin{array}{r}\text { Wt. } \\
\%\end{array}$ & $\begin{array}{l}255 \\
50.2\end{array}$ & $\begin{array}{l}4 \\
0.8\end{array}$ & $\begin{array}{c}102 \\
20.1\end{array}$ & $\begin{array}{l}78 \\
15.4\end{array}$ & $\begin{array}{c}19 \\
3.7\end{array}$ & $\begin{array}{l}36 \\
7.1\end{array}$ & $\begin{array}{c}14 \\
2.7\end{array}$ \\
\hline $1 \mathrm{lo}$ & 88,93 & $\begin{array}{r}\text { Wt. } \\
\%\end{array}$ & $\begin{array}{c}575 \\
63.9\end{array}$ & $\begin{array}{l}41 \\
4.6\end{array}$ & $\begin{array}{l}73 \\
8.1\end{array}$ & $\begin{array}{c}169 \\
18.8\end{array}$ & $\begin{array}{l}31 \\
3.4\end{array}$ & $\begin{array}{l}0 \\
-\end{array}$ & $\begin{array}{l}11 \\
1.2\end{array}$ \\
\hline 2 lo & & $\begin{array}{r}\text { Wt. } \\
\%\end{array}$ & $\begin{array}{c}352 \\
63.2\end{array}$ & $\begin{array}{l}0 \\
-\end{array}$ & $\begin{array}{l}93 \\
16.7\end{array}$ & $\begin{array}{c}22 \\
3.9\end{array}$ & $\begin{array}{c}18 \\
3.2\end{array}$ & $\begin{array}{l}0 \\
-\end{array}$ & $\begin{array}{l}72 \\
12.9\end{array}$ \\
\hline
\end{tabular}

$\mathrm{MBC} / \mathrm{T} / \mathrm{G}=$ Medium Banded Cream and Tan or Gray; MW = Medium White; FTB $/ \mathrm{T}=$ Fine Translucent Brown; FP = Fine Pink; FDG = Fine Dark Gray

able proportions. The medium-textured banded materials are more common in samples analyzed from operations 1 and 6 , the area of massive building walls. Either there was more manufacturing or greater use of the utilized knives (made on large blade segments) here. In contrast, the finer translucent materials are more common in samples from operations 2 and 5 , areas of domestic units, both elaborate and modest. The one consistently occurring material that may be imported-Medium White flint-occurs in all areas, and variations in proportion are not statistically significant.

\section{FUTURE RESEARCH POSSIBILITIES}

In many respects, the flaked stone industries from Hacınebi Tepe seem typical of fourth-millennium assemblages from throughout greater Mesopotamia. The division into flake and blade trajectories is reported from Hassek Hüyük, Jebel Aruda, and Farukhabad, all of which are medium-sized sites in areas with local raw material supplies. ${ }^{75}$ The internal differentiation into areas with more knives, other areas with more sickles, etc., is also reported from Farukhabad ${ }^{76}$ and probably exists at other sites as well. The evidence of wide distribution of imported

${ }^{75}$ M. Behm-Blancke ed., Hassek Höyük naturwissenschaftliche Untersuchungen und lithische Industrie (Tübingen 1992); J. Hanbury-Tenison, "The 1982 Flaked Stone Assemblage materials within the community is also known from Farukhabad.

Clearly this study is based on only a fraction of the samples recovered. Its results are provocative rather than definitive. There are several directions for future studies. First, we must expand the number of samples analyzed. In order to estimate rates of production and discard, we will have to analyze far more samples that have been carefully screened. Second, it would be useful to develop a form for recording the attributes of standardized flake blanks and tools parallel to that already in use for blades. Third, we need more thorough studies of microwear and residues, which require equipment not available locally.

\section{MUSEUM OF ANTHROPOLOGY \\ UNIVERSITY OF MICHIGAN \\ ANN ARBOR, MICHIGAN 48109-1079 \\ HENRY.WRIGHT@UM.CC.UMICH.EDU}

SEMINAR FÜR VORDERASIATISCHE ALTERTUMSKUNDE FREIE UNIVERSITÄT BERLIN

BITTERSTRASSE 8-12

14195 BERLIN

GERMANY

at Jebel Aruda, Syria," Akkadica 33 (1983) 27-39; Wright (supra n. 65) 43, 136, 266-67.

${ }^{76}$ Wright (supra n. 65) 174-76, tab. 46. 


\title{
HACINEBI TEPE 1993: ARCHAEOBOTANICAL REPORT
}

\author{
Naomi F. Miller
}

During the 1993 excavation season at Hacınebi, approximately 83 soil samples were taken from Late Chalcolithic and Achaemenid-Hellenistic contexts. The floated material is now at the University of Pennsylvania Museum (MASCA). The examination of 19 of these samples supplements the results obtained from seven samples analyzed in $1992 .{ }^{77}$ This report repeats some of the data presented earlier because information has been added from the heavy fractions sorted in the field in 1993 and some of the 1992 determinations have been corrected (table 8$).^{78}$

Hacınebi Tepe lies on the border between steppe and open oak forest. ${ }^{79}$ Today, pistachio groves cover the surrounding countryside and the site itself. A variety of plants common to the Anatolian Artemisia and grassy steppe and other open ground plant associations grow on Hacinebi Tepe. Archaeobotanical analysis has concentrated on the Late Chalcolithic (fourth-millennium) deposits. It was hoped that distinctive chronological, ethnic, or functional aspects of ancient plant use would become apparent because 1) the Late Chalcolithic deposits include an early (phase A) and a late (phase B) component, 2) the late component includes a physically distinct "Uruk" area, and 3) several different simple "domestic" areas were excavated. At this point it is only possible to say either that no such distinctions existed or that too few samples bearing on these questions have been studied.

As was true of the samples analyzed in 1992, the plant remains consist of charred wood, seeds, and other plant parts (mainly cereal straw and rachis frag. ments). There is also a small component of uncharred, possibly ancient seeds. The seed types include cultigens and wild plants. No pure caches of crop plants were encountered (table 9).

${ }_{77}$ N.F. Miller, "Appendix 1: Some Archaeobotanical Re mains from the 1992 Excavation Season at Hacinebi Tepe," Anatolica 20 (1994) 168-72.

${ }^{78}$ Guillermo Algaze kindly offered to have the Titriş Project process the Hacinebi samples. Abbas Kartal floated the samples using the system built by Mark Nesbitt, then of the British Institute of Archaeology in Turkey. Kartal also sorted the heavy fraction larger than about $5 \mathrm{~mm}$. I extracted plant remains from the residue that remained in a $2 \cdot \mathrm{mm}$ mesh sieve. Soil volume was recorded in liters at the time of processing, and is reported in table 9 .

In the laboratory, the flotation samples were poured into a set of nested sieves $(4.75 \mathrm{~mm}, 2 \mathrm{~mm}, 1 \mathrm{~mm}, 0.5 \mathrm{~mm}$, and $0.088 \mathrm{~mm}$ ). All whole seeds larger than $0.5 \mathrm{~mm}$ were separated out, as were seed and identifiable rachis frag.

\section{CROP AND FOOD PLANTS}

Barley (Hordeum vulgare) is the most common and numerous crop seed type in these samples, about $80 \%$ of the cereal identified to species. The barley may belong to the six-row type; among the recognizable intact grains, 23 could be twisted and 13 are definitely straight. Rachis internodes also occur. Three kinds of domesticated wheat have been rec ognized. Einkorn (Triticum monococcum) and emmer (Triticum dicoccum) are of approximately equal im portance in the Hacınebi assemblage, about $8 \%$ each of the cereal identified to species. Spikelet forks might come from either of these two types. Bread wheat or durum (Triticum aestivum/durum) is a minor component. Two pulses have been identified, lentil (Lens) and grasspea (Lathyrus). Today lentils are generally reserved for human food. Grasspea is almost invariably fed to animals, because consumption of large quantities of this pulse leads to lathyrism, a potentially fatal condition. ${ }^{80}$

The only unequivocal fruit remains are the few remains of grape (Vitis vinifera) pips or peduncles. Most of this evidence comes from the possibly mixed sample, HN333, but we can now add a fragment from HN1150 (Late Chalcolithic phase A). Grape is not unexpected, because it grows naturally in the Euphrates valley. ${ }^{81}$ Elsewhere along the Euphrates (e.g., at Kurban Höyük), there are a few finds of Late Chalcolithic grape. Grape does not seem to have become an important part of the economy anywhere in the Near East until the third millennium, ${ }^{82}$ by which time it was domesticated. Some tentatively identified fig (Ficus) seeds occur. Fig trees occur in the native vegetation of the area in a wide variety of habitats. ${ }^{83}$

Small quantities of nutshell have been found. Sur-

ments larger than $1 \mathrm{~mm}$. Material larger than $2 \mathrm{~mm}$ was completely sorted. A binocular stereoscopic microscope (7.5-75 $\times$ ) was used. Identifications are based on seed illus. trations from seed atlases, archaeobotanical reports, and modern comparative material.

${ }^{79}$ M. Zohary, Geobotanical Foundations of the Middle East (Stuttgart 1973).

${ }^{80}$ W. Lewis and M. Elvin-Lewis, Medical Botany (New York 1977) 44.

${ }^{81}$ D. Zohary and P. Spiegel-Roy, "Beginnings of Fruit Growing in the Old World," Science 187 (1975) 319-27.

${ }^{82}$ N.F. Miller, "The Near East," in W. van Zeist, K.E. Behre, and K. Wasylikowa eds., Progress in Old World Palaeoethnobotany (Rotterdam 1991) 133-60, 150.

${ }^{83}$ Cf. P. Davis ed., Flora of Turkey 7 (Edinburgh 1982) 644. 
Table 8. Catalogue of Analyzed Flotation Samples from Hacınebi

\begin{tabular}{|c|c|c|c|c|c|c|}
\hline Op. & Locus & Lot & $\begin{array}{c}\mathrm{HN} \\
\text { no. }\end{array}$ & $\begin{array}{c}\text { Date } \\
\text { Analyzed }\end{array}$ & $\begin{array}{c}\text { Late } \\
\text { Chalco- } \\
\text { lithic } \\
\text { Phase }\end{array}$ & $\begin{array}{c}\text { Deposit } \\
\text { Type }\end{array}$ \\
\hline 1 & 11 & 11 & 226 & $10 / 8 / 92$ & B & fill \\
\hline 1 & 13 & 16 & 241 & $10 / 9 / 92$ & B-Local & fill \\
\hline 1 & 20 & 27 & 326 & 10/7/92 & B & fill \\
\hline 1 & 21 & 25 & 320 & $10 / 16 / 92$ & B & fill \\
\hline 1 & 30 & 30 & 333 & $10 / 28 / 92$ & B & pit \\
\hline 1 & 34 & 37 & 388 & $10 / 16 / 92$ & B & fill \\
\hline 1 & 98 & 112 & 1150 & $11 / 29 / 93$ & A2 & pit \\
\hline 1 & 101 & 115 & 1162 & $11 / 29 / 93$ & A2 & trash \\
\hline 2 & 28 & 69 & 888 & $11 / 23 / 93$ & A2 & ash \\
\hline 2 & 29 & 70 & 927 & $11 / 29 / 93$ & A2 & ash \\
\hline 2 & 31 & 71 & 932 & $11 / 24 / 93$ & A2 & $?$ \\
\hline 4 & 34 & 77 & 2149 & $11 / 17 / 93$ & $\begin{array}{l}\text { B-Late } \\
\text { Local }\end{array}$ & ash \\
\hline 4 & 46 & 106 & 2442 & $12 / 6 / 93$ & $\mathrm{~B}$ & fire \\
\hline 4 & 49 & 111 & 2463 & $12 / 3 / 93$ & B & pit \\
\hline 4 & 52 & 115 & 2477 & $12 / 6 / 93$ & B & pit \\
\hline 5 & 25 & 47 & 1528 & $11 / 15 / 93$ & - & trash \\
\hline 5 & 37 & 63 & 1582 & $11 / 16 / 93$ & - & ash \\
\hline 5 & 46 & 81 & 1973 & $11 / 12 / 93$ & - & trash \\
\hline 5 & 49 & 89 & 1988 & $11 / 15 / 93$ & - & trash \\
\hline 5 & 57 & 98 & 2026 & $11 / 15 / 93$ & - & ash \\
\hline 5 & 58 & 100 & 2028 & $11 / 11 / 93$ & - & fire \\
\hline 6 & 46 & 56 & 2688 & $11 / 30 / 93$ & B-Local & fill \\
\hline 1 & 12 & 10 & 205 & $10 / 15 / 92$ & B-Uruk & fill \\
\hline 4 & 33 & 75 & 2138 & $12 / 2 / 93$ & B-Uruk & pit \\
\hline 4 & 36 & 83 & 2173 & $11 / 24 / 93$ & B-Uruk & pit \\
\hline 7 & 27 & 38 & 2236 & $11 / 24 / 93$ & B-Uruk & pit \\
\hline
\end{tabular}

face pitting on some suggests that these may be almond (Prunus sp.). Other fragments may include pistachio (Pistacia sp.). Had the heavy fraction been left unsorted, almost no nutshell would have been found. Only a few seed fragments of flax (Linum sp.) were found. The remains do not allow one to determine whether it was the fiber or oil crop, or just a naturally occurring wild plant.

Crop and food plants that occur primarily in fragmentary form have been recorded by weight. For those who prefer to see seed counts, plausible conversion figures based on whole seeds from Hacınebi appear in table 10 .

\section{WILD PLANTS}

The small amount of wood charcoal identified so far is primarily oak (Quercus), ${ }^{84}$ but the area around Hacinebi was not dense forest. For that reason, the wild plants probably represent a combination of

\footnotetext{
${ }^{84}$ Miller (supra n. 77) and general impression from scanning 1993 samples.

${ }^{85}$ For mineralization vs. charring, see discussion in $\mathrm{W}$.
}

steppe-forest plants, field weeds, and riparian vegetation. Most of the genera are known from other sites in southeastern Turkey and northern Syria. Some of the taxa found archaeologically today grow on the bluff top and slope surrounding Hacinebi's grove (e.g., grasses such as Hordeum murinum -type, Hordeum spontaneum-type, Aegilops, Taeniatherum caput-medusae, Avena; small-seeded legumes such as Astragalus, Medi. cago; and Hypericum [St. John's wort] and Papaver [poppy]), or in the grove itself (e.g., Heliotropium). Many of the plants characteristic of the uncultivated area today (e.g., Artemisia, Capparis spinosa) or the disturbed areas (e.g., Prosopis, Peganum harmala, Cynodon dactylon, Tribulus terrestris) have not been seen in the archaeological samples examined to date.

The most numerous seeds tend to be the most ubiquitous. Grasses dominate the assemblage, especially Lolium and as yet undetermined Gramineae 1 (cf. Phleum-type) and Gramineae 2. A smallseeded legume, clover or melilot (Trifolium/Melilotus), is widespread, though not particularly numerous.

Uncharred seeds, primarily members of the borage family, were also encountered. They are listed in table 9, but have not been included in the numerical comparisons. There is a good chance that many are not ancient, and even if ancient, their numbers are not directly comparable to the charred seeds due to different circumstances of preservation. ${ }^{85}$

\section{DISTRIBUTION OF TYPES IN SPACE AND TIME}

At Hacınebi, 61 taxa have been recognized to genus or species. A cumulative frequency graph of these 61 seed types shows that as more samples are analyzed, taxa are likely to be added to the assemblage, though at a diminishing rate. Now, after 26 samples have been analyzed, the rate of the addition of new taxa seems to be leveling off. The trend of data in figure 33 suggests that new types will continue to be discovered; only two-thirds of these types were found in the first 12 samples analyzed. This means that we are just beginning to understand the range of types found in the Late Chalcolithic levels. (The Achaemenid-Hellenistic samples are especially likely to include new taxa.) Most of the types represent only minor components of the assemblage (e.g., about a third occur in only one sample apiece). For that reason presence/absence differences among the minor components are more readily explained by chance than by major functional or environmental variables. Examination of only the most frequent taxa

van Zeist and $\mathrm{H}$. Buitenhuis, "Palaeobotanical Studies of Neolithic Erbaba, Turkey," Anatolica 10 (1983) 47-89; Miller (supra n. 82) 155. 
Table 9. Plant Remains from Hacinebi Tepe

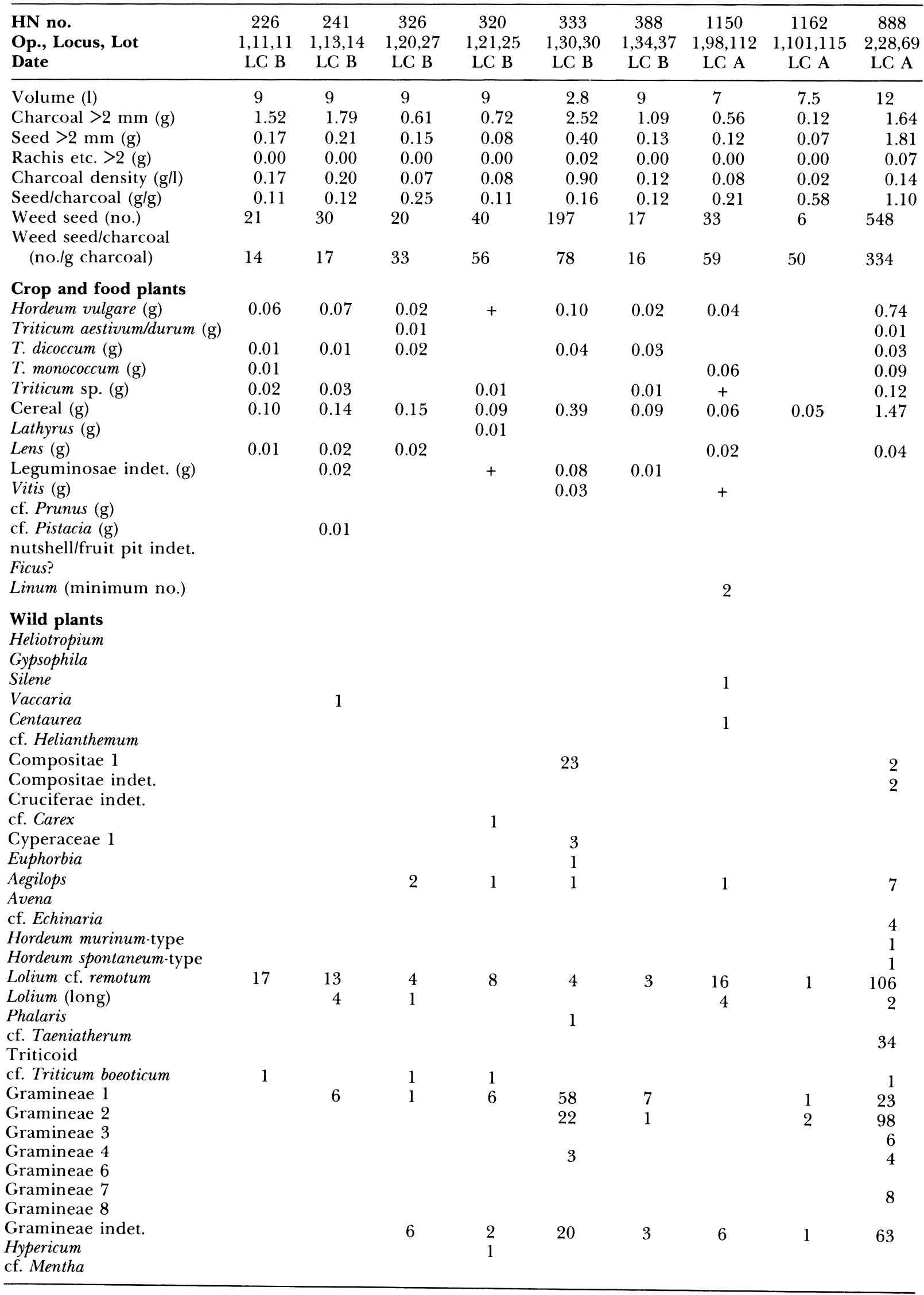


Table 9. (continued)

\begin{tabular}{|c|c|c|c|c|c|c|c|c|c|}
\hline $\begin{array}{l}\text { HN no. } \\
\text { Op., Locus, Lot } \\
\text { Date }\end{array}$ & $\begin{array}{c}226 \\
1,11,11 \\
\text { LC B }\end{array}$ & $\begin{array}{c}241 \\
1,13,14 \\
\text { LC B }\end{array}$ & $\begin{array}{c}326 \\
1,20,27 \\
\text { LC B }\end{array}$ & $\begin{array}{c}320 \\
1,21,25 \\
\text { LC B }\end{array}$ & $\begin{array}{c}333 \\
1,30,30 \\
\text { LC B }\end{array}$ & $\begin{array}{c}388 \\
1,34,37 \\
\text { LC B }\end{array}$ & $\begin{array}{c}1150 \\
1,98,112 \\
\text { LC A }\end{array}$ & $\begin{array}{l}1162 \\
1,101,115 \\
\text { LC A }\end{array}$ & $\begin{array}{c}888 \\
2,28,69 \\
\text { LC A }\end{array}$ \\
\hline
\end{tabular}

Teucrium

Labiatae 1

1

Labiatae indet.

Alhagi

Astragalus

Coronilla

Medicago

Trifolium/Melilotus

Trigonella astroites-type

Trigonella

Vicia/Pisum

Leguminosae (misc.)

Bellevalia

Ornithogalum-type

Malvaceae indet.

Papaver

Adonis

Galium

Thymelaea

Bupleurum?

Umbelliferae indet.

Valerianella

Valerianella dentata-type

Verbena officinalis

Unknowns

$\begin{array}{lll}1 & & \\ 1 & 1 & 2 \\ & & \\ & & \\ & \end{array}$

1

Uncharred seeds

Alkanna

Arnebia decumbens

Lithospermum tenuifolium

Boraginaceae indet.

Labiatae indet.

Fumaria

\section{Plant parts}

Hordeum internode

Triticum aestivum/durum internode

Triticum mono/dicoccum spikelet fork

Aegilops glume base

cf. Taeniatherum

rachis frag.

Grass culm node

Vitis penduncle

Misc. unk.

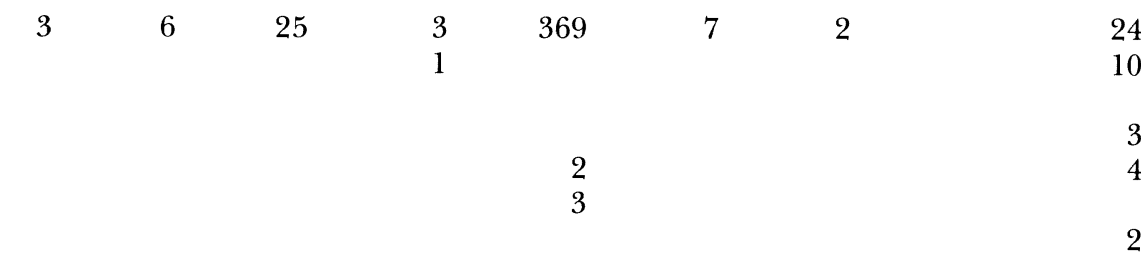

\begin{tabular}{lccccccccc}
\hline HN no. & 927 & 932 & 2149 & 2442 & 2463 & 2477 & 1528 & 1582 & 1973 \\
Op., Locus, Lot & $2,29,70$ & $2,31,71$ & $4,37,77$ & $4,46,104$ & $4,49,111$ & $4,52,11$ & $5,25,47$ & $5,37,63$ & $5,46,81$ \\
Date & LC A & LC A & LC B & LC B & LC B & LC B & LC & LC & LC \\
\hline Volume (l) & 8 & 8.75 & 1 & 9.25 & 8.5 & 9 & 6 & 7 & 9 \\
Charcoal >2 mm (g) & 0.66 & 1.30 & 9.98 & 0.56 & 0.75 & 0.20 & 0.07 & 0.24 & 1.68 \\
Seed >2 mm (g) & 0.04 & 0.30 & 0.01 & 0.10 & 0.41 & 0.13 & 0.02 & 0.08 & 0.36 \\
Rachis etc. >2 (g) & 0.01 & 0.03 & 0.00 & 0.00 & 0.00 & 0.00 & 0.01 & 0.00 & 0.03 \\
Charcoal density (g/l) & 0.08 & 0.15 & 9.98 & 0.06 & 0.09 & 0.02 & 0.01 & 0.03 & 0.19 \\
$\begin{array}{l}\text { Seed/charcoal (g/g) } \\
\text { Weed seed (no.) }\end{array}$ & 0.06 & 0.23 & 0.00 & 0.18 & 0.55 & 0.65 & 0.29 & 0.33 & 0.21 \\
Weed seed/charcoal & 30 & 89 & 0 & 13 & 23 & 12 & 9 & 32 & 89 \\
$\quad$ (no./g charcoal) & 45 & 68 & 0 & 23 & 31 & 60 & 129 & 133 & 53 \\
\hline
\end{tabular}


Table 9. (continued)

\begin{tabular}{|c|c|c|c|c|c|c|c|c|c|}
\hline $\begin{array}{l}\text { HN no. } \\
\text { Op., Locus, Lot } \\
\text { Date }\end{array}$ & $\begin{array}{c}927 \\
2,29,70 \\
\text { LC A }\end{array}$ & $\begin{array}{c}932 \\
2,31,71 \\
\text { LC A }\end{array}$ & $\begin{array}{c}2149 \\
4,37,77 \\
\text { LC B }\end{array}$ & $\begin{array}{c}2442 \\
4,46,104 \\
\text { LC B }\end{array}$ & $\begin{array}{c}2463 \\
4,49,111 \\
\text { LC B }\end{array}$ & $\begin{array}{c}2477 \\
4,52,11 \\
\text { LC B }\end{array}$ & $\begin{array}{c}1528 \\
5,25,47 \\
\text { LC }\end{array}$ & $\begin{array}{c}1582 \\
5,37,63 \\
\text { LC }\end{array}$ & $\begin{array}{c}1973 \\
5,46,81 \\
\text { LC }\end{array}$ \\
\hline $\begin{array}{l}\text { Crop and food plants } \\
\text { Hordeum vulgare }(\mathrm{g})\end{array}$ & 0.04 & 013 & + & 004 & 099 & 007 & + & 003 & 0.13 \\
\hline $\begin{array}{l}\text { Triticum aestivum/durum }(\mathrm{g}) \\
\text { T. dicoccum }(\mathrm{g})\end{array}$ & & 0.02 & & & & & & 0.02 & 0.01 \\
\hline T. monococcum $(\mathrm{g})$ & & & & & 0.01 & & & + & 0.02 \\
\hline Triticum sp. (g) & + & 0.04 & & & 0.01 & 0.03 & + & & 0.02 \\
\hline Cereal $(\mathrm{g})$ & 0.04 & 0.17 & & 0.07 & 0.16 & 0.18 & 0.06 & 0.07 & 0.29 \\
\hline Lathyrus (g) & & 0.03 & & & & & & & 0.01 \\
\hline Lens $(\mathrm{g})$ & & + & + & 0.01 & & & & & \\
\hline $\begin{array}{l}\text { Leguminosae indet. (g) } \\
\text { Vitis (g) }\end{array}$ & & + & & & & & & & \\
\hline $\begin{array}{l}\text { cf. Prunus }(\mathrm{g}) \\
\text { cf. Pistacia }(\mathrm{g})\end{array}$ & & & & + & & & & & 0.01 \\
\hline $\begin{array}{l}\text { nutshell/fruit pit indet. } \\
\text { Ficus? }\end{array}$ & & 0.01 & & & 0.01 & & & & \\
\hline Linum (minimum no.) & & & & & & & & & 1 \\
\hline $\begin{array}{l}\text { Wild plants } \\
\text { Heliotropium }\end{array}$ & & & & & & & & & \\
\hline Gypsophila & & & & & & & & & 1 \\
\hline Silene & & & & & & & & & 1 \\
\hline Vaccaria & & 1 & & & 1 & & & & 2 \\
\hline Centaurea & & & & & & & & & \\
\hline cf. Helianthemum & & & & & & 1 & & & \\
\hline Compositae 1 & & & & 1 & & 1 & & & \\
\hline Compositae indet. & & & & & & & & & \\
\hline Cruciferae indet. & & & & & & & & & 4 \\
\hline $\begin{array}{l}\text { cf. Carex } \\
\text { Cyperaceae } 1 \\
\text { Euphorbia }\end{array}$ & & 1 & & & & & & 1 & \\
\hline Aegilops & & 4 & & & & & & & 3 \\
\hline Avena & & & & & & & & & \\
\hline cf. Echinaria & & & & & & 1 & & & 2 \\
\hline $\begin{array}{l}\text { Hordeum murinum-type } \\
\text { Hordeum spontaneum-type }\end{array}$ & & 1 & & & & & & & 1 \\
\hline Lolium cf. remotum & 3 & 16 & & 3 & 4 & 1 & 3 & 13 & 12 \\
\hline $\begin{array}{l}\text { Lolium (long) } \\
\text { Phalaris }\end{array}$ & & & & & 1 & & & & \\
\hline $\begin{array}{l}\text { cf. Taeniatherum } \\
\text { Triticoid } \\
\text { cf. Triticum boeoticum }\end{array}$ & & 8 & & & & & & & \\
\hline Gramineae 1 & 3 & 3 & & 9 & & & 2 & & 21 \\
\hline Gramineae 2 & 19 & 18 & & & & & & & \\
\hline Gramineae 3 & & & & & & & & 1 & \\
\hline Gramineae 4 & & 1 & & & & & & & 2 \\
\hline Gramineae 6 & & & & & & & & 2 & \\
\hline Gramineae 7 & & 7 & & & & & & & \\
\hline Gramineae 8 & 1 & & & & & & & & \\
\hline $\begin{array}{l}\text { Gramineae indet. } \\
\text { Hypericum } \\
\text { cf. Mentha }\end{array}$ & 2 & 15 & & & 1 & 3 & & 12 & 17 \\
\hline Teucrium & & & & & 3 & & & & 1 \\
\hline $\begin{array}{l}\text { Labiatae } 1 \\
\text { Labiatae indet. }\end{array}$ & & & & & & & & & \\
\hline Alhagi & & 1 & & & & & & & \\
\hline Astragalus & & 1 & & & 2 & & & & \\
\hline Coronilla & & & & & & & & & \\
\hline Medicago & & & & & & 1 & & & \\
\hline Trifolium/Melilotus & & 1 & & & 3 & & & & 3 \\
\hline Trigonella astroites-type & 2 & 2 & & & & & & 1 & 1 \\
\hline
\end{tabular}


Table 9. (continued)

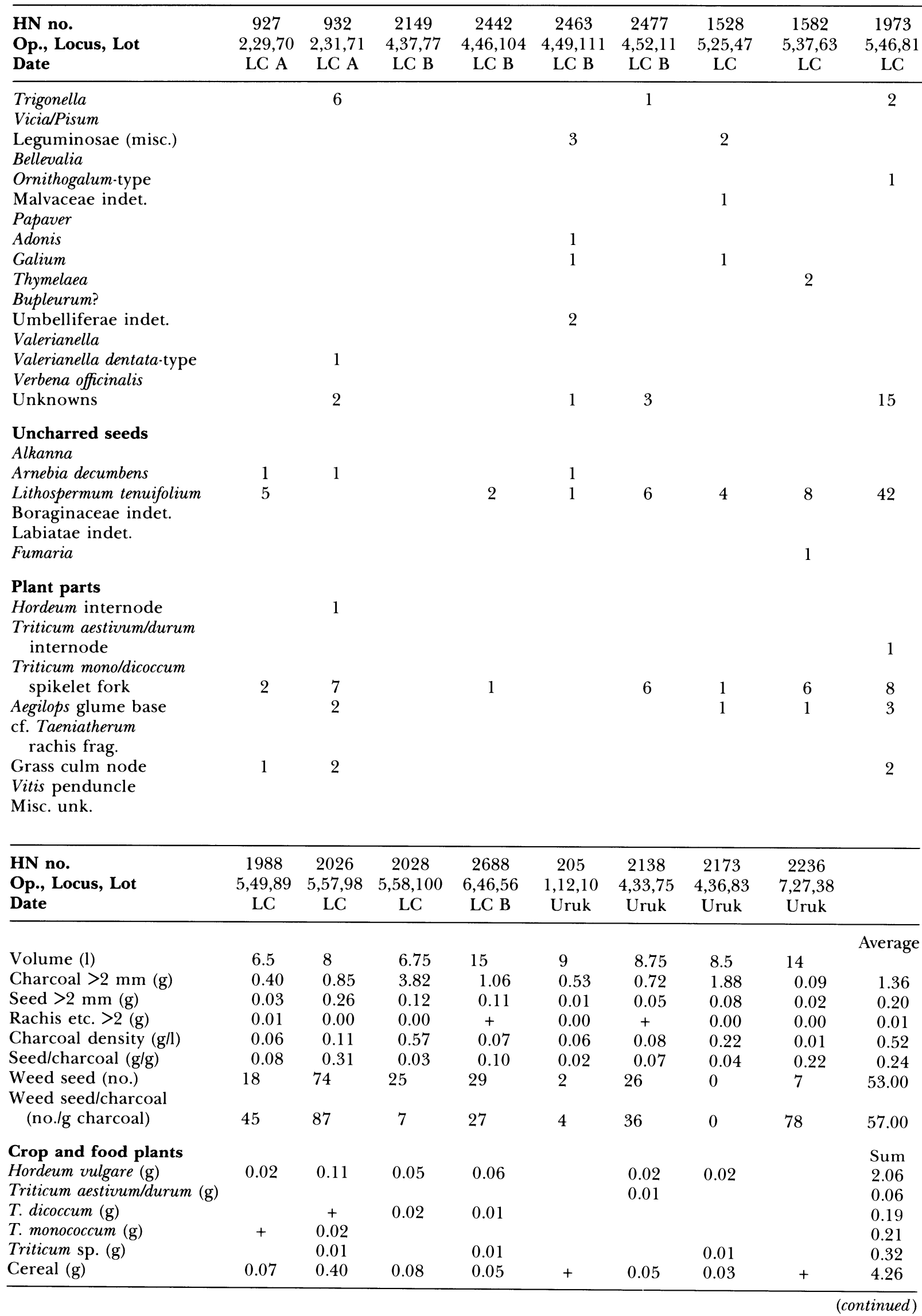


Table 9. (continued)

\begin{tabular}{|c|c|c|c|c|c|c|c|c|c|}
\hline $\begin{array}{l}\text { HN no. } \\
\text { Op., Locus, Lot } \\
\text { Date }\end{array}$ & $\begin{array}{c}1988 \\
5,49,89 \\
\text { LC }\end{array}$ & $\begin{array}{c}2026 \\
5,57,98 \\
\text { LC }\end{array}$ & $\begin{array}{c}2028 \\
5,58,100 \\
\text { LC }\end{array}$ & $\begin{array}{c}2688 \\
6,46,56 \\
\text { LC B }\end{array}$ & $\begin{array}{c}205 \\
1,12,10 \\
\text { Uruk }\end{array}$ & $\begin{array}{c}2138 \\
4,33,75 \\
\text { Uruk }\end{array}$ & $\begin{array}{c}2173 \\
4,36,83 \\
\text { Uruk }\end{array}$ & $\begin{array}{c}2236 \\
7,27,38 \\
\text { Uruk }\end{array}$ & \\
\hline & & & & & & & & & Sum \\
\hline Lathyrus (g) & & 0.01 & 0.01 & & & & & & 0.07 \\
\hline Lens $(\mathrm{g})$ & & + & & & & & 0.01 & & 0.13 \\
\hline Leguminosae indet. (g) & & & & & & & & & 0.11 \\
\hline Vitis $(\mathrm{g})$ & & & & & & & & & 0.03 \\
\hline cf. Prunus (g) & & & & & 0.01 & & & & 0.02 \\
\hline cf. Pistacia (g) & & & & & & & & & 0.01 \\
\hline nutshell/fruit pit indet. & + & & 0.05 & & & & & & 0.07 \\
\hline Ficus? & & & & & & 8 & 1 & & 9 \\
\hline Linum (minimum no.) & & 1 & & & & & & & 4 \\
\hline Wild plants & & & & & & & & & Sum \\
\hline Heliotropium & & & & 1 & & & & & 1 \\
\hline Gypsophila & & & & & & & & & 1 \\
\hline Silene & & & & & & & & & 2 \\
\hline Vaccaria & & & & & & & & 1 & 6 \\
\hline Centaurea & & & & & & & & & 1 \\
\hline cf. Helianthemum & & & & & & & & & 1 \\
\hline Compositae 1 & & & & & & & & & 27 \\
\hline Compositae indet. & & & & & & 1 & & & 3 \\
\hline Cruciferae indet. & & & & & & & & & 4 \\
\hline cf. Carex & & & & & & & & & 3 \\
\hline Cyperaceae 1 & & & & & & & & & 3 \\
\hline Euphorbia & & & & & & & & & 1 \\
\hline Aegilops & & 1 & & & & & & & 20 \\
\hline Avena & & 1 & & & & & & & 1 \\
\hline cf. Echinaria & & 1 & 1 & & & 1 & & & 10 \\
\hline Hordeum murinum-type & & & 2 & & & 1 & & & 6 \\
\hline Hordeum spontaneum-type & & 1 & & & & & & & 2 \\
\hline Lolium cf. remotum & 5 & 13 & 2 & 9 & & 2 & & 1 & 259 \\
\hline Lolium (long) & & & & 1 & & & & & 13 \\
\hline Phalaris & & & & & & & & & 1 \\
\hline cf. Taeniatherum & & & & & & & & & 42 \\
\hline Triticoid & & & & & & & & 1 & 1 \\
\hline cf. Triticum boeoticum & & & & & & & & & 3 \\
\hline Gramineae 1 & 4 & 8 & 1 & 2 & & & & & 155 \\
\hline Gramineae 2 & & & & $\overline{1}$ & & & & 1 & 162 \\
\hline Gramineae 3 & & & & & & & & & 7 \\
\hline Gramineae 4 & & 1 & & & & & & & 11 \\
\hline Gramineae 6 & & & & & & & & & 2 \\
\hline Gramineae 7 & & 2 & & & & & & & 17 \\
\hline Gramineae 8 & & & & & & & & & 1 \\
\hline Gramineae indet. & 4 & 24 & 12 & 4 & & 2 & & 3 & 200 \\
\hline Hypericum & 1 & & & & & & & & 2 \\
\hline cf. Mentha & & & & 1 & & & & & 1 \\
\hline Teucrium & & & & 1 & & & & & 6 \\
\hline Labiatae 1 & & & & & & & & & 1 \\
\hline Labiatae indet. & & & & & & 1 & & & 1 \\
\hline Alhagi & & & & & & & & & 2 \\
\hline Astragalus & & & & & & & & & 7 \\
\hline Coronilla & & & & 1 & & & & & 9 \\
\hline Medicago & & & & & & & & & 4 \\
\hline Trifolium/Melilotus & 1 & 7 & & 1 & 2 & & & & 40 \\
\hline Trigonella astroites-type & & & & 1 & & & & & 36 \\
\hline Trigonella & 1 & 1 & 1 & & & & & & 50 \\
\hline VicialPisum & & 1 & & & & & & & 1 \\
\hline Leguminosae (misc.) & & & & & & & & & 12 \\
\hline Bellevalia & & & & & & & & & 1 \\
\hline Ornithogalum-type & & & 3 & & & & & & 4 \\
\hline Malvaceae indet. & & & & & & & & & 1 \\
\hline
\end{tabular}


Table 9. (continued)

\begin{tabular}{|c|c|c|c|c|c|c|c|c|c|}
\hline $\begin{array}{l}\text { HN no. } \\
\text { Op., Locus, Lot } \\
\text { Date }\end{array}$ & $\begin{array}{c}1988 \\
5,49,89 \\
\text { LC }\end{array}$ & $\begin{array}{c}2026 \\
5,57,98 \\
\text { LC }\end{array}$ & $\begin{array}{c}2028 \\
5,58,100 \\
\text { LC }\end{array}$ & $\begin{array}{c}2688 \\
6,46,56 \\
\text { LC B }\end{array}$ & $\begin{array}{c}205 \\
1,12,10 \\
\text { Uruk }\end{array}$ & $\begin{array}{c}2138 \\
4,33,75 \\
\text { Uruk }\end{array}$ & $\begin{array}{c}2173 \\
4,36,83 \\
\text { Uruk }\end{array}$ & $\begin{array}{c}2236 \\
7,27,38 \\
\text { Uruk }\end{array}$ & \\
\hline & & & & & & & & & Sum \\
\hline Papaver & & & & & & & & & 4 \\
\hline Adonis & & & & & & & & & 1 \\
\hline Galium & & 2 & & & & & & & 14 \\
\hline Thymelaea & & & & & & & & & 3 \\
\hline Bupleurum? & & 1 & & & & & & & 1 \\
\hline Umbelliferae indet. & & & 1 & & & & & & 5 \\
\hline Valerianella & & 1 & 1 & & & & & & 2 \\
\hline Valerianella dentata-type & & & & & & & & & 1 \\
\hline Verbena officinalis & & & & & & & & & 1 \\
\hline Unknowns & 2 & 9 & 1 & 6 & & 18 & & & 213 \\
\hline Uncharred seeds & & & & & & & & & Sum \\
\hline Alkanna & & & & & & & & 2 & 3 \\
\hline Arnebia decumbens & & & & & & & & & 3 \\
\hline Lithospermum tenuifolium & 4 & 16 & 3 & 2 & & 1 & 4 & 12 & 140 \\
\hline Boraginaceae indet. & & 1 & & & & & & & 1 \\
\hline Labiatae indet. & & & & & & & 1 & & 2 \\
\hline Fumaria & & 4 & & & & 1 & & & 6 \\
\hline Plant parts & & & & & & & & & Sum \\
\hline Hordeum internode & & 1 & & 1 & & & & & 15 \\
\hline $\begin{array}{l}\text { Triticum aestivum/durum } \\
\text { internode }\end{array}$ & & & & & & & & & 1 \\
\hline Triticum mono/dicoccum & & & & & & & & & \\
\hline spikelet fork & 3 & 28 & 4 & 3 & 1 & 2 & 2 & & 513 \\
\hline Aegilops glume base & 1 & & & & & 1 & & & 20 \\
\hline cf. Taeniatherum & & & & & & & & & \\
\hline rachis frag. & & 1 & & & & & & & 4 \\
\hline Grass culm node & & & & 1 & & & & & 12 \\
\hline Vitis penduncle & & & & & & & & & 3 \\
\hline Misc. unk. & & & & & & & & & 2 \\
\hline
\end{tabular}

(those occurring in at least four samples) reveals no discernible differences between the various time periods and excavation areas (table 11).

\section{DEPOSITIONAL AND CHRONOLOGICAL FACTORS}

The samples have been assigned to different depositional types, which can be categorized roughly as fire installation (e.g., oven), pit, ash deposit, trashy fill, and building collapse/fill. At a gross level, the deposits are for the most part quite similar to one another, and therefore seem to reflect similar depositional processes, namely, mixed trash disposal. Two deposits stand out: HN888 (ash) and HN2149 (ash pit). HN888 has an unusually high concentration of both wild and cultivated seeds. The proportion of wild seeds to seed fragments greater than $2 \mathrm{~mm}$ (primarily cereals) is no different from that of other samples, and like most of the other samples, the weed seed assemblage includes all size fractions. In short, the high density of charred seeds in this deposit is likely to reflect a relatively intact trash de- posit filled with the remains of burnt dung fuel and perhaps crop-processing debris. ${ }^{86}$ Sample HN2149 has an unusually high concentration and proportion of wood charcoal, which might suggest it is the relatively intact remains of a wood-fueled fire.

The four Uruk samples examined to date are not unique in any way, in quantity of material, relative

Table 10. Average Weight of Whole Crop Seeds at Hacınebi Tepe

\begin{tabular}{lccc}
\hline & \multicolumn{3}{c}{ Total Wt. } \\
Type & $\begin{array}{c}\text { No. } \\
\text { (g) } \\
\text { (whole) }\end{array}$ & $\begin{array}{c}\text { Wt. } \\
\text { (whole) }\end{array}$ & (g) \\
\hline Hordeum & 93 & 0.94 & 0.01 \\
Triticum monococcum & 18 & 0.18 & 0.01 \\
Triticum dicoccum & 18 & 0.15 & 0.008 \\
Triticum aestivum/durum & 7 & 0.05 & 0.007 \\
Lens & 12 & 0.12 & 0.01 \\
Lathyrus & 2 & 0.02 & 0.01 \\
Vitis & 2 & 0.02 & 0.01 \\
\hline
\end{tabular}

Note: the samples contain no whole Pistacia or Prunus. 


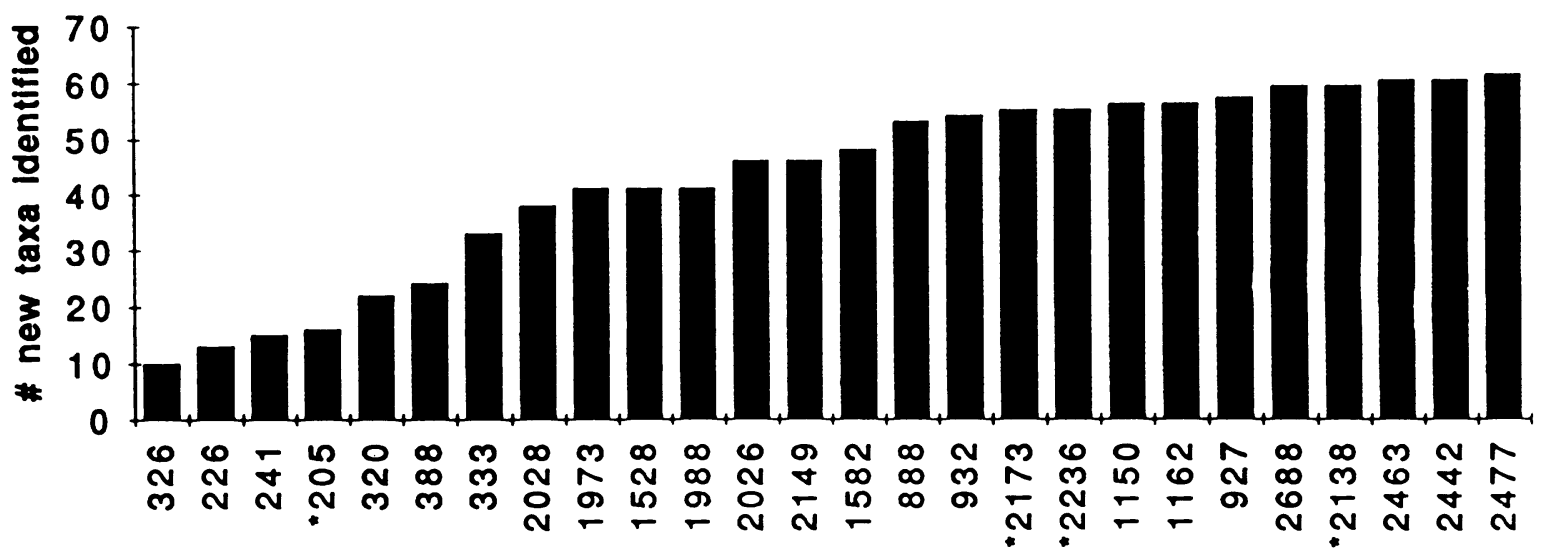

HN no. (":Uruk sample)

Fig. 33. Addition of new identified taxa with increasing numbers of analyzed archaeobotanical samples

Table 11. Presence/Absence of Common Types, by Late Chalcolithic (LC) Phase

\begin{tabular}{|c|c|c|c|c|c|}
\hline & \multicolumn{5}{|c|}{ Phase } \\
\hline & $\begin{array}{c}\text { Ubiqui } \\
\text { tous }\end{array}$ & LC & $\mathrm{LC} \mathrm{A}$ & LC B & Uruk \\
\hline \multicolumn{6}{|l|}{ No. samples } \\
\hline per phase & & 6 & 5 & 11 & 4 \\
\hline \multicolumn{6}{|l|}{ Analyzed soil } \\
\hline sample vol. (l) & & 43 & 43 & 91 & 40 \\
\hline \multicolumn{6}{|l|}{ Charcoal } \\
\hline (total, g) & & 7.06 & 4.28 & 20.80 & 3.22 \\
\hline Seed (total, g) & & 0.87 & 2.34 & 1.90 & 0.16 \\
\hline Rachis (total, g) & & 0.05 & 0.11 & 0.02 & 0.00 \\
\hline Hordeum vulgare & 23 & $\mathbf{x}$ & $\mathbf{x}$ & $\mathbf{x}$ & $\mathbf{x}$ \\
\hline Lolium cf. remotum & 23 & & $\mathbf{x}$ & $\mathbf{x}$ & $\mathbf{x}$ \\
\hline Gramineae 1 & 16 & & $\mathbf{x}$ & $\mathbf{x}$ & \\
\hline Trifolium/Melilotus & 16 & & $\mathbf{x}$ & $\mathbf{x}$ & $\mathbf{x}$ \\
\hline Triticum dicoccum & 10 & & $\mathbf{x}$ & $\mathbf{x}$ & \\
\hline Lens & 9 & & $\mathbf{x}$ & $\mathbf{x}$ & $\mathbf{x}$ \\
\hline \multicolumn{6}{|l|}{ Trigonella } \\
\hline astroites-type & 9 & & $\mathbf{x}$ & $\mathbf{x}$ & \\
\hline Galium & 9 & & $\mathrm{x}$ & $x$ & \\
\hline \multicolumn{6}{|l|}{ Triticum } \\
\hline monococcum & 8 & & $\mathrm{x}$ & $\mathrm{x}$ & \\
\hline Gramineae 2 & 8 & & $\mathbf{x}$ & $\mathbf{x}$ & $\mathrm{x}$ \\
\hline Aegilops & 7 & $\mathbf{x}$ & $\mathbf{x}$ & $\mathbf{x}$ & \\
\hline Trigonella & 7 & $\mathbf{x}$ & $\mathbf{x}$ & $\mathrm{x}$ & \\
\hline cf. Echinaria & 6 & $\mathbf{x}$ & $\mathbf{x}$ & $\mathbf{x}$ & $\mathbf{x}$ \\
\hline Lolium (long) & 6 & & $\mathrm{x}$ & $\mathrm{x}$ & \\
\hline \multicolumn{6}{|l|}{ Triticum } \\
\hline aestivum/durum & 5 & $\mathbf{x}$ & $\mathbf{x}$ & & $\mathbf{x}$ \\
\hline Lathyrus & 5 & $\mathbf{x}$ & $\mathbf{x}$ & & \\
\hline Vaccaria & 5 & & $\mathbf{x}$ & $\mathbf{x}$ & $\mathbf{x}$ \\
\hline Hordeum murinum- & & & & & \\
\hline type & 5 & & $\mathbf{x}$ & & $\mathbf{x}$ \\
\hline Gramineae 4 & 5 & $\mathbf{x}$ & $\mathbf{x}$ & $\mathbf{x}$ & \\
\hline Compositae 1 & 4 & & $\mathbf{x}$ & $\mathbf{x}$ & \\
\hline Teucrium & 4 & $\mathbf{x}$ & & $\mathbf{x}$ & \\
\hline Astragalus & 4 & & $\mathbf{x}$ & $\mathbf{x}$ & \\
\hline Coronilla & 4 & & $\mathbf{x}$ & $\mathrm{x}$ & \\
\hline
\end{tabular}

amounts of seeds and charcoal, or taxa recovered. Differences between trenches, and between early and late deposits are not pronounced enough to be seen in just 26 samples. ${ }^{87}$ It is therefore not yet possible to discuss functional differences or chronological developments.

\section{COMPARISONS WITH OTHER SITES \\ ON THE EUPHRATES RIVER}

The Hacınebi assemblage is quite similar to that of Late Chalcolithic Kurban Höyük, which lies about $100 \mathrm{~km}$ upstream..$^{88}$ This is not surprising, as the climate and natural vegetation of the two sites are similar. The small differences between the two assemblages during the Late Chalcolithic are attributable to the fact that Kurban Höyük enjoys slightly higher rainfall than Hacinebi. ${ }^{89}$ In particular, at both sites barley is by far the most important crop, although wheat also occurs with some frequency. Hacinebi and Kurban share other crop and food plants as well (lentil, grasspea, flax, grape, and nuts). Overlap in the wild seed assemblage is substantial, which probably reflects similarities in field weeds and steppe vegetation around the two sites.

\footnotetext{
${ }^{87}$ Hacınebi is typical of many sites of the ancient Near East, where variability within samples is so high that in order to see patterning between samples large numbers of samples must be analyzed.

${ }^{88}$ N.F. Miller, "Vegetation and Land Use," in G. Algaze et al., "The Chicago Euphrates Archaeological Project 1980-1984: An Interim Report," Anatolica 13 (1986) 85-89, 119-20.

89 N.F. Miller, "Environmental Constraints and Cultural Choices along the Euphrates between the Fourth and Second Millennia B.C.," paper presented at the 59th Annual Meeting of the Society for American Archaeology, Anaheim, Calif. 1994.
} 
The later third-millennium sites of Tell es-Sweyhat and Selenkahiye in Syria provide some interesting contrasts..$^{90}$ Located at the southern edge of the dryfarming zone, about $100 \mathrm{~km}$ downstream from Hacınebi, Selenkahiye and Sweyhat have cereal remains that are nearly all two-row barley; einkorn, emmer, and bread wheat/durum are very uncommon. Two-row barley needs less moisture than both the six-row type and the wheats. As at Kurban Höyük, there is a fairly large overlap in the wild seed assemblage at the level of genus. Some of the differences probably reflect differences in the native vegetation; for example, wild einkorn, absent from the Syrian sites, is at the southern edge of its range near Hacınebi.

\section{AVENUES FOR FUTURE RESEARCH}

Hacınebi Tepe has two contemporary, but physically separate, cultural components, an indigenous Late Chalcolithic one and an intrusive Uruk one (with Mesopotamian affinities). Archaeobotanical research on local Late Chalcolithic deposits has established the characteristics of the agricultural economy, and shown it to be similar to that of contemporary Kurban Höyük. As environmental constraints on agriculture were necessarily shared by the incoming and local populations at Hacinebi, identification of differences between the archaeobotanical assem. blages of the newcomers and the indigenous people would suggest how strongly cultural traditions influenced agriculture and land use practices. More Uruk samples must be collected and analyzed before this aspect of life on the Euphrates will be explicated.

It would also be useful to analyze more of the local Late Chalcolithic samples, both pre- and post-contact. Even if they yield similar information, we could be more confident that the results already reached are reliable (i.e., that analyzing a few more samples will not radically change the characterization).

Charcoal analysis will also enhance the picture of environment and land use at Hacınebi Tepe. After the detailed stratigraphy is worked out, it may be possible to detect change in the arboreal vegetation. In contrast to crop choice, over which people exercise great control by virtue of what they sow, wood use in the Chalcolithic reflects what is already growing in the area, and is therefore a more sensitive indicator of vegetation change at Hacinebi.

MUSEUM APPLIED SCIENCE CENTER
FOR ARCHAEOLOGY (MASCA)
UNIVERSITY OF PENNSYLVANIA MUSEUM
OF ARCHAEOLOGY AND ANTHROPOLOGY
33RD AND SPRUCE STREETS
PHILADELPHIA, PENNSYLVANIA 19104
NMILLER@SAS.UPENN.EDU

\section{LATE CHALCOLITHIC FAUNAL REMAINS FROM HACINEBI}

\section{Gil J. Stein and Jeffrey Nicola}

\section{INTRODUCTION}

The collection of zooarchaeological data from Hacınebi is a long-term project geared toward study. ing synchronic variation and diachronic change in patterns of animal use at Hacinebi. In the 1992-1993 seasons, 854 lots of animal bone (an estimated 36,000 fragments) were recovered; most of this material derives from Late Chalcolithic contexts. Bone was recovered in two ways: collection in the course of excavation, and dry-sieving of the excavated sediments in a $0.5 \cdot \mathrm{cm}$ mesh. Generally, primary (in situ) and secondary (e.g., midden) deposits were dry-sieved, while tertiary (redeposited materials, wash, or mudbrick collapse) deposits were not. Material recovered in the course of excavation was bagged separately

\footnotetext{
${ }^{90} \mathrm{~W}$. van Zeist and J.A.H. Bakker-Heeres, "Archaeobotanical Studies in the Levant 4: Bronze Age Sites on the North Syrian Euphrates," Palaeohistoria 27 (1988) 247-316;
}

from material recovered from dry-sieving; this permits the controlled comparison of recovery rates between the different methods of data collection. All bone fragments were saved, washed, and brought back to the U.S. for analysis in the Northwestern University Zooarchaeology Laboratory.

Given the small size of the sample processed to date, the following discussion is limited to a comparison of the two phases over the site as a whole. Once a larger sample of fauna has been analyzed, intrasite comparisons among the northern, south ern, and western areas will be possible. The faunal data are presented as numbers of identified speci. mens (NISP, often called "fragment counts") rather than as minimum numbers of individuals (MNI), be.

C. Hide, "Archaeobotanical Remains from Tell es-Sweyhat, Northwest Syria," MASCA Ethnobotanical Laboratory Report 7 (Philadelphia 1990). 
Table 12. Hacınebi Phases A and B: Total Number of Identified Specimens (NISP)

\begin{tabular}{lrrrrr}
\hline & \multicolumn{2}{c}{ Phase A } & & \multicolumn{2}{c}{ Phase B } \\
\cline { 2 - 3 } \cline { 5 - 6 } & NISP & \% NISP & & NISP & \% NISP \\
\hline Sm. bird & 2 & 0.16 & & 0 & 0.00 \\
Med. bird & 0 & 0.00 & & 1 & 0.04 \\
Med. carniv. & 2 & 0.16 & & 2 & 0.09 \\
Lg. carniv. & 1 & 0.08 & & 0 & 0.00 \\
Sm. mamm. & 56 & 4.56 & & 40 & 1.76 \\
Med. mamm. & 368 & 29.99 & & 993 & 43.74 \\
Lg. mamm. & 51 & 4.16 & & 255 & 11.23 \\
Rodent & 1 & 0.08 & & 0 & 0.00 \\
Fish & 1 & 0.08 & & 0 & 0.00 \\
Bos & 106 & 8.64 & & 38 & 1.67 \\
Ovis/Cap./Gazella & 8 & 0.65 & & 61 & 2.69 \\
Ovis/Capra & 154 & 12.55 & & 168 & 7.40 \\
Ovis & 11 & 0.90 & & 15 & 0.66 \\
Capra & 3 & 0.24 & & 4 & 0.18 \\
Sus & 110 & 8.96 & & 51 & 2.25 \\
Gazella & 1 & 0.08 & & 3 & 0.13 \\
Cervus & 5 & 0.41 & & 1 & 0.04 \\
Dama & 1 & 0.08 & & 1 & 0.04 \\
Canis & 1 & 0.08 & & 1 & 0.04 \\
Ursus & 1 & 0.08 & & 0 & 0.00 \\
Indet. & 344 & 28.04 & & 636 & 28.02 \\
TOTALS & 1,227 & 100.00 & & 2,270 & 100.00 \\
\hline & & & & &
\end{tabular}

cause MNI data are especially sensitive to small sample size; ${ }^{91}$ these two measures of relative abun. dance generally converge with large sample sizes. ${ }^{92}$

A sample of 3,497 Late Chalcolithic animal bone fragments from the 1992-1993 field seasons was analyzed (table 12). ${ }^{93}$ This represents phases $\mathrm{A}$ and B from both the northern (ops. 1 and 6) and the southern (ops. 2 and 7) areas of the site. Of the total sample, 744 fragments, or $21.28 \%$, were identified to genus; the remaining $78.72 \%$ were identified in more general size/taxonomic terms. The following discussion focuses on the fauna identified to the genus level.

\section{PHASE A FAUNA}

It was possible to identify 401 bone fragments from phase $A$ to the genus level. Wild animals such as red deer (Cervus), fallow deer (Dama mesopotamica), gazelle, and bear together constitute about $2 \%$ of the frag.

\footnotetext{
${ }^{91}$ D. Grayson, Quantitative Zooarchaeology (New York 1984) 129.

92 R. Casteel, "A Consideration of the Behaviour of the Minimum Number of Individuals Index: A Problem in Faunal Characterization," Ossa 3/4 (1976-1977) 141-51.

${ }^{93} \mathrm{~J}$. Nicola, Changing Patterns of Economic Organization at Hacinebi Tepe, 3800-3000 B.C.: A Zooarchaeological Analysis (Senior Honors Thesis, Northwestern Univ. 1994); Stein
}

Table 13. Percentages of Main Taxa Identified to Genus: Hacınebi Phases A and B

\begin{tabular}{lrrrrr}
\hline & \multicolumn{2}{c}{ Phase A } & & \multicolumn{2}{c}{ Phase B } \\
\cline { 2 - 3 } \cline { 6 - 6 } \cline { 5 - 6 } & NISP & \% NISP & & NISP & \% NISP \\
\hline Ovis/Capra & 176 & 43.89 & & 248 & 72.30 \\
Bos & 106 & 26.43 & & 38 & 11.08 \\
Sus & 110 & 27.43 & & 51 & 14.87 \\
Other & 9 & 2.24 & & 6 & 1.75 \\
TOTALS & 401 & 100.00 & & 343 & 100.00 \\
\hline
\end{tabular}

ments. As is commonly the case for fourth- and third-millennium assemblages from the dry farming zone of northern Syria and southeastern Anatolia, almost $98 \%$ of the phase A sample consists of caprines (sheep and goats), pigs, and cattle - the main domesticated animals of the ancient Near East (table 13). Sheep and goats are the most common taxa, to gether comprising almost $44 \%$ of the identified fauna; among these, sheep outnumber goats by a ratio of almost 4:1. Pigs form the second most common component $(27.43 \%)$, with cattle a close third $(26.43 \%)$. The fact that pigs and cattle form more than half of the phase A faunal assemblage suggests a relatively diversified herding economy. Diversifica. tion of this sort is consistent with the risk-averting strategies of village-based herders focused on subsistence-level production for local use. ${ }^{94}$ The relative proportions of head, axial, limb, and foot bones present in the phase A faunal sample are consistent with local butchery and consumption, rather than export or import of specific body parts.

\section{PHASE B FAUNA}

It was possible to identify 343 fragments from phase $\mathrm{B}$ deposits to the genus level. As in the earlier phase A, sheep and goats comprise the most common taxa, with pigs second and cattle third. The percentages of the different animals, however, suggest that patterns of animal use were significantly different during the period of extensive contact with Uruk Mesopotamia. When fauna from all phase B areas of Hacınebi are combined for analysis, caprines increase from $43.89 \%$ in phase A to over $72 \%$ during phase B, while pigs and cattle drop from ca. $50 \%$

(supra n. 44).

${ }^{94}$ G. Stein, "Regional Economic Integration in Early State Societies: Third Millennium B.C. Pastoral Production at Gritille, Southeast Turkey," Paléorient 13 (1987) 101-11; Stein, "Strategies of Risk Reduction in Herding and Hunt. ing Systems of Neolithic South Anatolia," in P. Crabtree, D. Campana, and K. Ryan eds., Early Animal Domestication and Its Cultural Context (Philadelphia 1989) 87-97. 


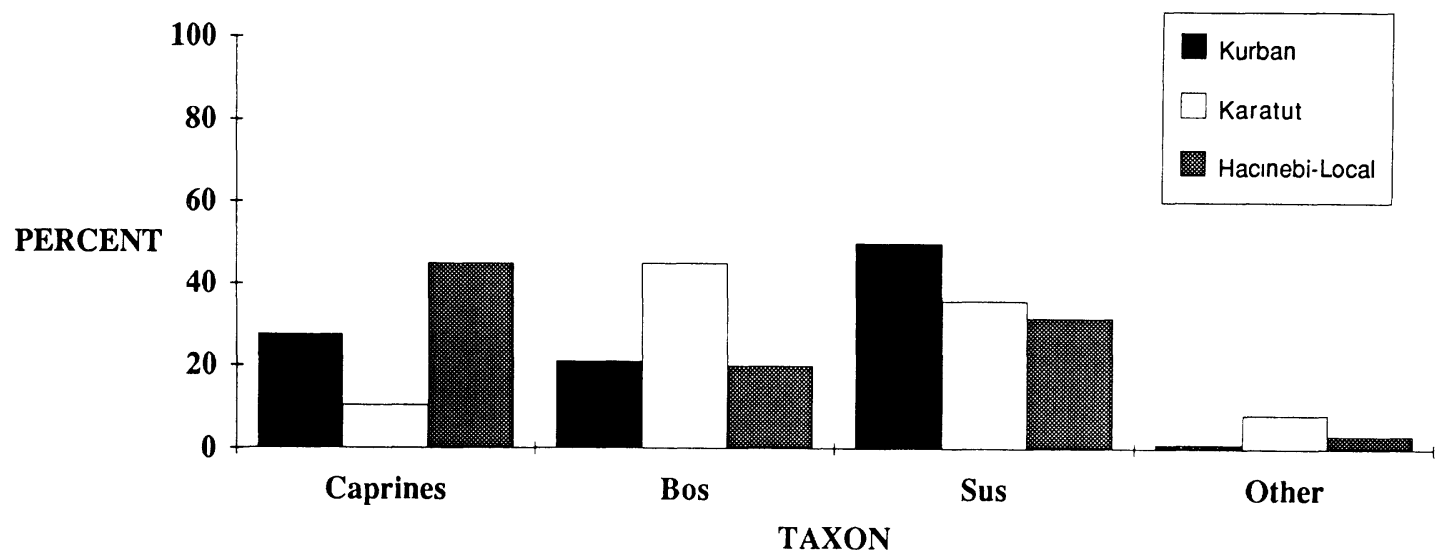

Fig. 34. Hacınebi phase B, operations 1 and 6: fauna from contexts with Local Late Chalcolithic ceramics compared with fauna from other Local Late Chalcolithic sites

to $26 \%$. When we break down the phase $\mathrm{B}$ data by context, however, some interesting contrasts appear in animal use between those deposits with Uruk ceramics, and those with Local Late Chalcolithic material.

This contrast is especially striking in the northern area of the site, where in operations 1 and 6 contemporaneous Uruk and local deposits were found on opposite sides of the same wall. The faunal sample analyzed to date is still extremely small, so all conclusions should be considered tentative. A sample of 736 fragments was analyzed from the Uruk de. posit. Of these, 125 (ca. $17 \%$ ) were identified to the genus level. From the local Anatolian deposit 466 fragments were analyzed; of these, 60 fragments (ca.
$13 \%$ ) were identified to the genus level. This small sample does, however, show that major differences exist in the relative abundances of different animal species on the two sides of the wall. In the local de posit, caprines (mainly sheep and goats) form only about $45 \%$ of the sample; pig is next in importance, at about $32 \%$, and cattle third at $20 \%$. This pattern reflects a fairly diversified herding system. The unusually high proportion of pigs at Hacınebi phase B continues the earlier phase A pattern of local faunal use, and is consistent with the pattern observed at other local Anatolian sites in the Euphrates valley such as Kurban Höyük and Karatut Mevkii (fig. 34). ${ }^{95}$ In a striking contrast to this pattern, in the Uruk deposit, caprines form $83 \%$ of the sample, with

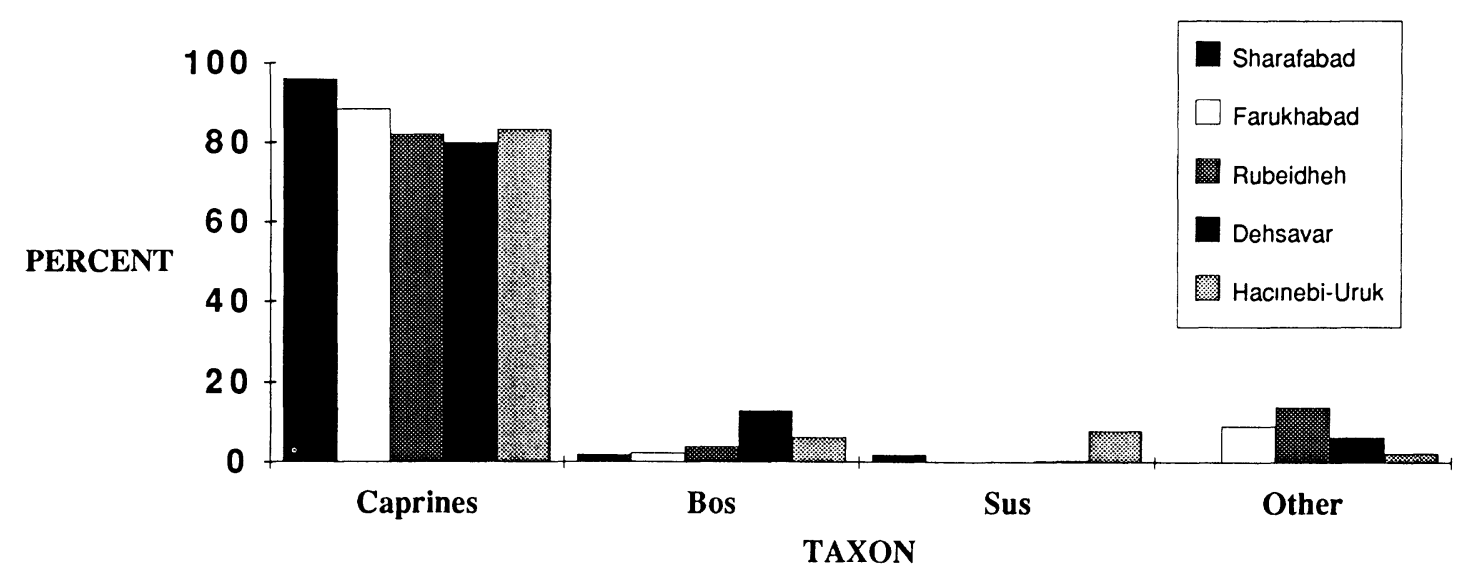

Fig. 35. Comparison of the relative percentages of faunal taxa from Mesopotamian Uruk and Hacinebi Uruk contexts

\footnotetext{
${ }_{95}$ P. Wattenmaker and G. Stein, "Early Pastoral Production in Southeast Anatolia: Faunal Remains from Kurban Höyük and Gritille Höyük," in Algaze et al. (supra n. 88) 90-96; Stein, "Analysis of Faunal Remains from Medieval
}

Occupation Levels at Gritille Höyük and Late Chalcolithic Soundings at Karatut Mevkii, Southeast Turkey," report on file at the University of Pennsylvania Museum of Archaeol. ogy and Anthropology. 
only small amounts of pig and cattle present. This predominance of caprines fits very closely with what little is known about patterns of Late Uruk animal use at sites like Rubeidheh and Farukhabad in Mesopotamia and Khuzistan, where caprines range from $80 \%$ to $96 \%$ of the faunal assemblages (fig. 35 ). ${ }^{96}$

In short, patterns of local Anatolian faunal use at Hacınebi show tremendous continuity between phases A and B (tables 12-13), and are closely similar to other Local Late Chalcolithic sites in the area. In those contact phase $\mathrm{B}$ deposits that have almost exclusively Uruk material culture, however, the faunal use patterns differ markedly from the Anatolian pattern; instead they closely match Mesopotamian food preferences. Thus, results from the preliminary analyses of the faunal data are consistent with the ce-

${ }^{96}$ S. Payne, "Animal Bones from Tell Rubeidheh," in R.G. Killick ed., Excavations at Tell Rubeidheh (Warminster 1988) ramic, glyptic, and other artifactual evidence in sug. gesting that a small enclave of Mesopotamians was present in the northern area of Hacinebi during phase B.

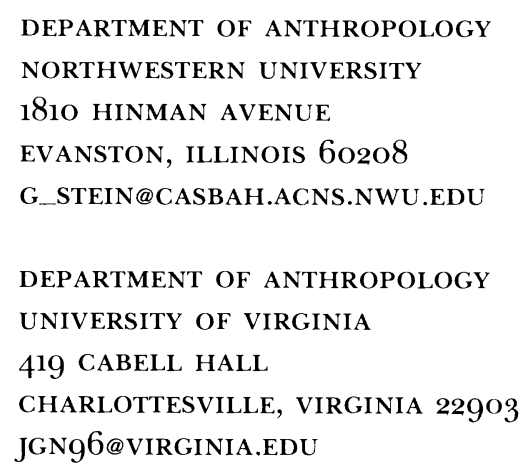

98-135; R. Redding, “The Faunal Remains," in Wright (supra n. 65) 233-61. 